UNIVERSIDADE DE SÃO PAULO

FACULDADE DE ODONTOLOGIA DE BAURU

MARIANA RODRIGUES SANTESSO

Avaliação da viabilidade celular e transportadores de membrana em linhagem de células epiteliais de rim tratados com fluoreto

\title{
BAURU
}

2018 


\title{
MARIANA RODRIGUES SANTESSO
}

\section{Avaliação da viabilidade celular e transportadores de membrana em linhagem de células epiteliais de rim tratados com fluoreto}

\author{
Dissertação apresentada a Faculdade de \\ Odontologia de Bauru da Universidade de São Paulo \\ para obtenção do título de Mestre em Ciências no \\ Programa de Ciências Odontológicas Aplicadas, na \\ área de concentração Biologia Oral.
}

Orientador: Prof. Dr. Rodrigo Cardoso de Oliveira

\section{BAURU}


Santesso, Mariana Rodrigues

Sa59a Avaliação da viabilidade celular e transportadores de membrana em linhagem de células epiteliais de rim tratados com fluoreto / Mariana Rodrigues Santesso. Bauru, 2018.

134 p. : il. ; $31 \mathrm{~cm}$.

Dissertação (Mestrado) - Faculdade de Odontologia de Bauru. Universidade de São Paulo

Orientador: Prof. Dr. Rodrigo Cardoso de Oliveira

Autorizo, exclusivamente para fins acadêmicos e científicos, a reprodução total ou parcial desta dissertação/tese, por processos fotocopiadores e outros meios eletrônicos.

Assinatura:

Data: 
FOLHA DE APROVAÇÃO 

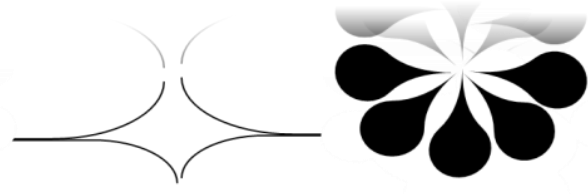

\section{DEDICATÓRIA}

Dedico este trabalho aos bens mais preciosas da minha vida. A única maneira que encontrei de referir-me a estes bens foi descrevendo como eu os vejo. Gostaria também de descrever o meu amor por eles, mas sei que isso não é possível, pois nem mesmo todas as palavras existentes seriam suficientes para explicar este sentimento tão sincero e singular. Eu os vejo como minha fonte de inesgotável de amor, esperança que surge e acalenta as dores, caminho eterno de ternura, asas que protegem durante a caminhada, mãos que se estendem a qualquer momento e braços que acolhem durante uma vida toda, determinação em um mar de dificuldades, persistência e coragem no meio da pior tempestade. Vejo-os como recomeço, para eles não existem batalhas perdidas, são como remédio que curam minhas feridas e revigoram minhas forças, são respostas quando tudo parece estar perdido, são vitória sem nem mesmo precisar ter ganho, são regozijo sem receber nada troca, eles são o motivo do meu mais sincero sorriso, eles são o verdadeiro significado do perdão, são a alegria e o ânimo mesmo quando não tem mais para onde correr, eles são a riqueza do mundo mascarada pela singela humildade, são a luz e orientação quando me encontro perdida, são fortaleza e escudo pelo resto da vida, são presentes de Deus, são graça e hora, são a compreensão em forma de abraço e o contentamento em forma de beijo,

são o reflexo da bondade, são imensidão de paz, são tudo para mim, eles são: meus pais.

José Geraldo Santesso e Maria Aparecida Rodrigues, obrigada amados pais por tanto amor, compreensão, apoio, perseverança, suporte e carinho nesta longa jornada que foi meu mestrado, chegar até aqui não foi fácil, mas com vocês por perto tudo se tornou mais alegre e ameno. Vocês são espelho para mim, vocês possuem todas as qualidades que um Deus bom falou para termos, no entanto em vocês existe o dobro. Mesmo sem merecer e mesmo com tantas dificuldades vocês acreditaram em mim e permanecem fiéis até 0 fim, eu sou muito grata por tê-los como meus pais. Pai sua bondade é eterna e seu coração é o mais lindo da face da terra, mãe seu carinho é imensurável e 
sua compaixão incalculável. Obrigada, obrigada, obrigada vocês são meus heróis de asas, o meu amor por vocês é incomparável, atravessa mares, desertos e até mesmo o universo para ir além do infinito.

Eu os admiro muito e anseio em orgulha-los, pois, prazer maior não há em vêlos felizes, espero poder retribuir tudo que fazem por mim. 


\section{AGRADECIMENTOS ESPECIAIS}

Este agradecimento vai para aquelas pessoas que mudaram a minha vida e por isso e eu serei eternamente grata. Agradeço imensamente:

Á querida Adriana Arruda, que apesar de ser uma pessoa totalmente admirável leva a humildade consigo e em todos os momentos demonstrou isso para comigo. Sempre muito positiva e confiante, tudo parecia muito fácil aos seus olhos, você me ajudou muito com a sua notória determinação e generosidade, além de ter me explicado tantas coisas e disponibilizado tanto de seu tempo comigo. Agradeço por tudo Dri você é uma amiga para o que der e vier! Muito obrigada!

Á Cintia Tokuhara, que além de amiga foi também minha salvação. Tantas e tantas vezes que você esteve ali prontamente a literalmente me salvar, sempre me apoiando e contornando as situações adversas com muita calma e paciência. É difícil falar sobre suas qualidades, pois, elas são inúmeras e você é na verdade um anjo disfarçado de ser humano, escrever sobre suas virtudes requer mais folhas. Cintia eu sou muito grata por toda ajuda, mas agradeço mais ainda por você ter cruzado meu caminho, você não sabe o quanto te admiro e o quanto suas qualidades me influenciam e me fazem querer ser melhor. Muito obrigada querida Ci!

Á Gabriela Neubern, que quando vi pela primeira vez pensei: "acho não vou gostar dela", mas aí é que esta a ironia, você é uma das pessoas que mais me sinto a vontade, além de que me conectar a você foi muito fácil, até porque, você com sua espontaneidade tornou isso muito fácil. Sim Gabi meu "santo" bateu com o seu, nossa amizade é despretensiosa, veio de forma muito natural, sem formalidades e esforço. Agradeço por toda ajuda e por esta amizade tão afável. Muito obrigada querida Gabi!

Ao João Paulo Domezi, com toda a sua bondade, seu coração enorme, e seu entusiasmo pela vida, fez meus dias no laboratório serem tão felizes e tão divertidos. Sempre muito zeloso com os amigos, sua sinceridade é uma de suas maiores 
virtudes, sempre de cabeça erguida contagia a todos com este brilho inato e sua alegria incessante. Muito obrigada por tudo João, obrigada ser meu amigo de todas as horas. Você é muito querido!

À Flavia Amadeu de Oliveira, minha amiga/inspiração, uma mulher cheia de virtudes e incrivelmente generosa, foi você quem me estendeu a mão tantas, e tantas vezes, e tantas vezes sem deixar que eu caísse, ou então mesmo caindo, me ajudou a levantar, sou grata a você por todas as lutas que enfrentamos juntas e por este coração tão lindo e cheio de bondade que só pode ter sido presente de Deus, devido a tamanha bondade e amor. Obrigada Flá você é muito querida!

Mariana Liessa, uma amiga tão carinhosa e meiga, sempre levando longanimidade para esta minha personalidade explosiva, sempre vendo as coisas boas nas adversidades e sempre uma pessoa presente em todos os momentos, obrigada querida Mari!

Meus amados irmãos Ana Paula Bandiciolli e Diego Santesso, que são meu suporte e fortaleza, meus amigos de sangue, minha alegria e fonte de risadas, meus eternos anjos da guarda e minha porção de amor em forma de DNA. Eu amo muito vocês!

Ao meu amado companheiro e amigo Fernando Henrique Tonon por trazer tanta luz a minha vida, por além de me fazer tão feliz, compartilhar comigo um sentimento tão genuíno e despretensioso que é o nosso amor. Obrigada por me ajudar de inúmeras formas, por jamais deixar de acreditar em mim. Todo o seu ser e toda a sua genialidade me cativam de tal maneira que, cada vez mais, busco melhorar para tentar me assemelhar a você a sua nobreza inata de valores, eu nunca saberei como retribuir tudo que você faz por mim. Obrigada por lutar e sonhar comigo, obrigada por me incentivar a ir mais alto e por ser também quem me levanta se eu vier a cair, você é esplêndido eu sou eternamente grata por você ter cruzado o meu caminho. 
Por fim, e não menos importante, agradeço o grande responsável por essa conquista, que esteve por trás deste espetáculo desde o início:

Ao meu grande mestre, sábio, tutor e orientador, Rodrigo Cardoso de Oliveira. Obrigada por todas as oportunidades, por ter aberto portas tão enormes para mim, por ter me dado ferramentas e asas para poder ir cada vez mais longe. Obrigada por ter sido supervisor, mas também, por ter sido amigo, por estar em uma posição acima, mas mesmo assim me tratar com muita igualdade e bondade, enfim, por ter sido um líder admirável. Todos esses anos você foi um verdadeiro exemplo para mim, um exemplo de caráter, de justiça, de compreensão, de atitude. Não conseguiria resumir você apenas pelas suas qualidades notáveis, pois você em sua totalidade é muito mais do que um líder no trabalho, um bom exemplo a ser seguido ou uma pessoa com qualidades valiosas, pois, você é grandioso por si só! Minha eterna gratidão a você professor! 


\section{AGRADECIMENTOS}

Agradeço de coração a todas as pessoas que me ajudaram, foram amigas e pacientes, bondosas e prestativas, firmes e assistentes, resumidamente: maravilhosas para comigo. Eu reconhecerei eternamente o que fizeram por mim. A participação de vocês foi fundamental para que eu chegasse até aqui!

À querida Professora Marília Afonso Rabelo Buzalaf, colaboradora deste projeto, por toda a ajuda, orientação, por ter trazido as células de tão longe e tê-las confiado a mim, além de uma exímia pesquisadora e professora sua personalidade serena e bondosa me trazia muita segurança e confiança, todo seu suporte foi imprescindível para meu crescimento pessoal e para este projeto.

Ao professor Michael Edwardson Stewart, também parceiro deste projeto, por toda ajuda e orientação no período que esteve no Brasil, e mesmo sem me conhecer confiou plenamente no meu trabalho e na minha capacidade, serei sempre muito grata pela oportunidade que me proporcionou para aprender coisas novas, mas e acima de tudo obrigada pela humildade e bondade.

À Flavia Levy, uma pessoa sem igual, sempre transbordando animação me apoiou em todos os momento e sempre fez questão de me proporcionar o melhor, sempre desejando a minha vitória e torcendo por mim, foi maravilhoso ter a sua torcida em momentos difíceis e não tão agradáveis, sempre me fazendo persistir! muito obrigada Flá, você é muito querida!

À Juliana Trevizol, uma menina meiga que sempre estava disposta a me ajudar, sempre serena, nunca perdia a calma ou a paciência comigo. Sua ajuda foi indispensável e eu aprendi muito trabalhando ao seu lado Jú, você é ótima!

À Ligia Subitoni Antonio pelo suporte e por sempre oferecer ajuda antes mesmo de eu pedir, obrigada por todos os ensinamentos e por ser tão acessível, disponibilizando seu tempo para mim. 
À querida Márcia Graeff, que é esplendida só por si só, mas ainda abdicou de todo seu conforto e até mesmo de seu tempo para me ajudar e deixar as minhas imagens perfeitas. Obrigada Márcia você fez tanto por mim, fico tão lisonjeada por tudo e pela amizade, você é admirável!

À Thelminha e ao Marcelo, que foram sempre muito prestativos, sempre amáveis. É muito bom estar perto de pessoas como vocês, pessoas que tem extrema bondade e compaixão pelos outros. Obrigada por cada dúvida sanada, cada pergunta respondida com um sorriso e satisfação no olhar, e pela paciência e ajuda a qualquer momento e qualquer hora.

Ao José Carlos Guareschi, sempre amigo e parceiro, muito entusiasmado e sempre disposto a fazer o melhor pelas pessoas, você é ótimo Carlinho, eu gosto muitíssimo de você!

Aos amigos que estão presentes não só na $\mathrm{FOB}$, mas também na vida, Heliton Gustavo de Lima, Karen Pinke, Rafaela Alves, Nara Lígia Martins Almeida, Pepe Burgos, Talita Ventura, Priscla Salomão, Camila Buzalaf muito obrigada, é sempre um prazer estar com vocês!

Ao Thiago José Dionísio, pela boa vontade de ajudar nos experimentos de RT-PCR e por estar sempre disposto a sanar minhas dúvidas.

À Dra. Tânia Cestari, por ter cedido seu tempo para me ensinar a quantificar as imagens de imunofluorescência e ainda por cima ter sido tao carinhosa e paciente.

Aos amigos da Bioquímica, Vinícius Pelá, Even Taira, Aline Dionízio, Mileni Fernandes, Isabela Tomazini, Tati Martini, Aline Braga, Daiane Morelli por serem tão gentis e tornarem o ambiente de trabalho tão feliz e gostoso.

Aos amigos da Histologia Rafa Ortiz, Cláudia Bighetti e Ever Laura Mena, vocês me acolheram tão bem e eu sou tão grata por esta amizade singela e verdadeira. Vocês não imaginam o quanto gosto de vocês, obrigada por tudo e pelo enorme carinho! 
À Aline Leite, pelo apoio e pela maneira esplendida de ensinar, é admirável seu conhecimento, eu aprendi muito com você, obrigada por tudo Aline!

À Larissa Grizzo por todo o auxílio nos mais variados momentos.

À CAPES, pelo apoio financeiro para a realização desta pesquisa.

À Faculdade de Odontologia de Bauru, pela oportunidade de fazer parte desta instituição tão renomada.

À Universidade de Cambridge, pela preciosa parceria.

Aos amigos de fora, pelo carinho e compreensão nos momentos em que precisei estar ausente. 
"Renda-se como eu me rendi. Mergulhe no que você não conhece como eu mergulhei. Pergunte sem querer a resposta como eu estou perguntando, não se preocupe em entender, viver ultrapassa qualquer entendimento."

Clarice Lispector

"Escolho meus amigos não pela pele ou outro arquétipo qualquer, mas pela pupila.

Tem que ter brilho questionador e tonalidade inquietante. A mim não interessa os bons de espírito nem os maus de hábito. Fico com aqueles que fazem de mim louco

e santo. Deles não quero resposta quero meu avesso. Que me tragam dúvidas e angustias e aguentem o que há de pior em mim. Para isso só sendo louco. Quero os santos, para que não duvidem das diferenças e peçam perdão pelas injustiças. Escolho meus amigos pela alma lavada e pela cara exposta. Não quero só ombro e colo, quero também sua maior alegria. Amigo que não ri junto, não sabe sofrer junto. Meus amigos são todos assim: metade bobeira, metade seriedade. Não quero risos previsíveis, nem choros piedosos. Quero amigos sérios, daqueles que fazem da realidade sua fonte de aprendizagem, mas lutam para que a fantasia não desapareça. Não quero amigos adultos e nem chatos. Quero-os metade infância e outra metade velhice! Crianças, para que não esqueçam o valor do vento no rosto; $e$ velhos, para que nunca tenham pressa. Tenho amigos para saber quem eu sou. Pois os vendo loucos e santos, bobos e sérios, crianças e velhos, nunca me esquecerei de que "normalidade" é uma ilusão imbecil e estéril."

Oscar Wilde

"Até aqui o Senhor nos ajudou!"

1 Samuel 7:12 


\section{RESUMO}

O balanço do fluoreto (F) dentro do corpo é modulado por sua ingestão, absorção e remoção, e os rins, responsáveis pela sua excreção do organismo, são particularmente vulneráveis à toxicidade do $\mathrm{F}$. Os efeitos nefrotóxicos do $\mathrm{F}$ envolvem mudanças estruturais marcantes nos rins, além disso, estudos proteomicos têm mostrado grandes alterações no perfil de proteínas envolvidas em pontos chave na transdução de sinal. Estes efeitos podem influenciar negativamente no transporte iônico nos rins. A vista deste fato, o transporte iônico no canal de sódio epitelial (ENaC) é limitante para a taxa de reabsorção de sódio nos rins, sendo essencial para a manutenção do equilíbrio eletrolítico e homeostase do corpo. Assim, este trabalho objetivou investigar os efeitos do $\mathrm{F}$, utilizando concentrações semelhantes às que podem ser encontradas no néfron durante a fluorose dentária, na viabilidade celular e expressão de transportadores de membrana (ENaC) em linhagem celular renal M-1. Para os ensaios de viabilidade das células da linhagem $M-1$ foi empregado os testes colorimétricos Cristal Violeta e MTT, utilizando as concentrações de tratamento com fluoreto de sódio (NaF) a 10, 40, 100, 200 e 400 $\mu \mathrm{M}$, durante períodos experimentais de 24, 48, 72 e $96 \mathrm{~h}$. As mesmas concentrações e os mesmos tempos foram utilizados no tratamento com cloreto de sódio $(\mathrm{NaCl})$, utilizado como controle na possível interferência de $\mathrm{Na}^{+}$na modulação das células. Para a investigação da influência do $F: 1)$ nos canais ENaC foi utilizada a técnica de imunofluorescência e 2) para a análise de expressão gênica das subunidades que formam o ENaC, foi utilizada a técnica RT-PCR. Em nossos resultados pudemos observar que as maiores concentrações tanto de $\mathrm{NaF}$ quanto de $\mathrm{NaCl}$ provocaram a diminuição da viabilidade celular para ambos os ensaios de viabilidade, no entanto, foi possível observar algumas diferenças na resposta do tratamento com $\mathrm{NaF}$ em comparação com $\mathrm{NaCl}$, por meio do ensaio Cristal Violeta. Não foi observado diferenças nas imagens de imunofluorescêcia, mas outros aspectos morfológicos foram vistos nessas imagens, como o aparecimento de "domes" celular, sugerindo que até mesmo a maior concentração de $\mathrm{F}$ não foi capaz de inibir a proliferação celular. Nosso resultado mais significativo foi em relação à expressão das subunidades dos canais de ENaC, onde a concentração de $400 \mu \mathrm{M}$ foi capaz de diminuir bruscamente a expressão das três subunidades do $\mathrm{ENaC}$, enquanto as concentrações de 100 e $200 \mu \mathrm{M}$ mostraram apresentar expressão igual e em alguns 
casos até maior que o grupo controle. Pudemos concluir que doses de $\mathrm{F}$ na ordem de micromolares podem modular a expressão das subunidades formadoras do $\mathrm{ENaC}$, positivamente quando em baixas concentrações e negativamente quando em concentrações elevadas.

Palavras-chave: Fluoreto. Células Renais. ENaC. 


\section{Evaluation of cell viability and membrane transporters in kidney epithelial cells}

lineage treated of fluoride

The balance of fluoride $(F)$ within the body is modulated by its ingestion, absorption and removal, and the kidneys, responsible for their excretion of the organism, are particularly vulnerable to the toxicity of $F$. The nephrotoxic effects of $F$ involve marked structural changes in the kidneys, in addition, proteomic studies have shown large changes in the profile of proteins involved in key points in signal transduction. These effects may negatively influence ion transport in the kidneys. In view of this fact, the ionic transport in the epithelial sodium channel $(\mathrm{ENaC})$ is limiting to the rate of sodium reabsorption in the kidneys, being essential for the maintenance of the electrolyte balance and homeostasis of the body. Thus, the objective of this work was to investigate the effects of $F$, using concentrations similar to those found in the nephron during dental fluorosis, cell viability and expression of membrane transporters $(\mathrm{ENaC})$ in renal cell line $\mathrm{M}-1$. For the $\mathrm{M}-1$ cell line viability assays, the Crystal Violet and MTT colorimetric assays were used, using the 10, 40, 100, 200 and $400 \mu \mathrm{M}$ sodium fluoride $(\mathrm{NaF})$ treatment concentrations during experimental periods of 24, 48, 72 and $96 \mathrm{~h}$. The same concentrations and the same times were used in the treatment with sodium chloride $(\mathrm{NaCl})$, used as control in the possible interference of $\mathrm{Na}+$ in the modulation of the cells. For the investigation of the influence of $\mathrm{F}: 1$ ) in the $\mathrm{ENaC}$ channels, the immunofluorescence technique was used and 2) for the analysis of gene expression of the subunits that form the ENaC, the RT-PCR technique was used. In our results it was observed that the higher concentrations of $\mathrm{NaF}$ and $\mathrm{NaCl}$ caused a decrease in cell viability for both viability assays, however, it was possible to observe some differences in $\mathrm{NaF}$ treatment response in comparison to $\mathrm{NaCl}$, through test Crystal Violet. No differences were observed in immunofluorescence images, but other morphological aspects were seen in these images, such as the appearance of cellular "domes", suggesting that even the highest $\mathrm{F}$ concentration was not able to inhibit cell proliferation. Our most significant result was the expression of the subunits of the $\mathrm{ENaC}$ channels, where the concentration of $400 \mu \mathrm{M}$ was able to decrease expression of the three subunits of the $\mathrm{ENaC}$, whereas the concentrations of 100 and $200 \mu \mathrm{M}$ showed equal expression and in some cases even higher than the control group. We can conclude that doses in the order of micromolar the $\mathrm{F}$ can modulate the expression of the $\mathrm{ENaC}$ forming 
subunits, positively when in low concentrations and negatively when in high concentrations.

Keywords: Fluoride. Kidney Cells. ENaC. 


\section{LISTA DE ILUSTRAÇÕES}

\section{- FIGURAS}

Figura 1 - Representação esquemática das principais estruturas do rim

Figura 2 - Principais estruturas do néfrom e mecanismo de ação da aldosterona sobre o canal de sódio epitelial e a bomba de sódio e potássio presentes na membrana apical e basolateral, respectivamente, das células epiteliais do túbulo contorcido distal.

Figura 3 - Resumo esquemático da regulação endócrina para a manutenção do equilíbrio hidro-eletrolítico.

Figura 4 - Proporções de concentração tecido/plasma de fluoretoem tecidos moles de ratos

Figura 5 - (A) Modelos de homologia de subunidades ENaC com base na estrutura cristalina do canal ASIC: a ENaC (verde), $\beta \mathrm{ENaC}$ (vermelho) e y ENaC (amarelo). (B) Configuração espacial das três subunidades unidas formando o canal de sódio epitelial (ENaC) na membrana celular.

Figura 6 - Mecanismo de reabsorção tubular do fluoreto.

Figura 7 - Fotomicrografia feita em aumento de 20x no microscópio de fase invertida (LEICA/ DM IRBE), de campo claro, das células da linhagem M-1 (ATCC CRL$2038^{\text {TM }}$.

Figura 8 - (A) fotomicrografia dos "domes" celulares formados em uma monocamada epitelial devido ao transporte para baixo de íons e água. (B) Foco superior no topo dos "domes". Microscópio de fase invertida LEICA/ DM IRBE, objetiva 20X. 
Figura 9 - Layout da placa de 48 poços utilizada nos ensaios de viabilidade celular. (A) Disposição do grupo controle, grupos de tratamento com $\mathrm{NaF}$ e branco na placa. (B) Disposição do grupo controle, grupos de tratamento com $\mathrm{NaCl}$ e branco na placa.

Figura 10 - Imagem ilustrativa da placa do ensaio Redução do MTT após incubação e posterior dissolução dos cristais de formazan com DMSO.

Figura 11 - Imagem ilustrativa da placa do ensaio de viabilidade cristal violeta após adição de citrato de sódio a 0,05 mol. $\mathrm{L}^{-1}$.

Figura 12 - Imagem ilustrativa do microscópio confocal a laser (Leica TCS SP5).

Figura 13 - Sistema de Real-Time RT-PCR ViiA ${ }^{\mathrm{TM}} 7$ (Applied Biosystems).

Figura 14 - Efeito das concentrações 10, 40, 100, 200 e $400 \mu \mathrm{M}$ de $\mathrm{NaF}$ e $\mathrm{NaCl}$ sobre a viabilidade de células da linhagem M-1. Estes resultados são referentes aos valores de absorbância obtidos pelo ensaio redução do MTT. Os valores são expressos em média \pm desvio padrão. Letras diferentes indicam diferenças estatísticas $(p<0,05)$ em relação ao grupo controle

Figura 15 - Efeito das concentrações 10, 40, 100, 200 e $400 \mu \mathrm{M}$ de NaF sobre a viabilidade de células da linhagem M-1. Estes resultados são referentes aos valores de absorbância obtidos pelo ensaio redução do MTT. Os valores são expressos em média \pm desvio padrão. Neste gráfico não foi possível observar diferenças entre os períodos de tempo dentro de um grupo experimental, visto que, os períodos não apresentaram diferença estatisticamente significativa entre si $(p<0,05)$.

Figura 16 - Efeito das concentrações 10, 40, 100, 200 e $400 \mu \mathrm{M}$ de $\mathrm{NaCl}$ sobre a viabilidade de células da linhagem $\mathrm{M}-1$. Estes resultados são referentes aos valores de absorbância obtidos pelo ensaio redução do MTT. Os valores são expressos em média \pm desvio padrão. Neste gráfico não foi possível observar diferenças entre os períodos de tempo dentro de um grupo experimental, visto que, os períodos não apresentaram diferença estatisticamente significativa. 
Figura 17 - Efeito das concentrações 10, 40, 100, 200 e $400 \mu \mathrm{M}$ de $\mathrm{NaF}$ e $\mathrm{NaCl}$ sobre a viabilidade de células da linhagem M-1 nos períodos de 24, 48, 72396 horas. Estes resultados são referentes aos valores de absorbância obtidos pelo ensaio Cristal Violeta. Os valores são expressos em médiatdesvio padrão. Letras diferentes indicam diferenças estatísticas $(p<0,05)$ em relação ao grupo controle.

Figura 18 - Efeito das concentrações 10, 40, 100, 200 e $400 \mu \mathrm{M}$ de NaF sobre a viabilidade de células da linhagem M-1. Estes resultados são referentes aos valores de absorbância obtidos pelo ensaio Cristal Violeta. Os valores são expressos em média \pm desvio padrão. Neste gráfico não foi possível observar diferenças entre os períodos de tempo dentro de um grupo experimental, visto que, os períodos não apresentaram diferença estatisticamente significativa entre si $(p<0,05)$.

Figura 19 - Efeito das concentrações 10, 40, 100, 200 e $400 \mu \mathrm{M}$ de $\mathrm{NaCl}$ sobre a viabilidade de células da linhagem M-1. Estes resultados são referentes aos valores de absorbância obtidos pelo ensaio Cristal Violeta. Os valores são expressos em médiatdesvio padrão. Neste gráfico somente as letras em maiúsculo iguais não apresentam diferenças estatisticamente significativas entre os períodos de tempo dentro de um grupo experimental $(p<0,05)$.

Figura 20 - Imagens adquiridas por microscopia confocal a laser, no aumento de $40 \mathrm{X}$, mostrando a marcação dos alvos Alfa e Gama, separadamente, nos grupos tratados com as concentrações de 100, 200 e $400 \mu \mathrm{M}$ de NaF, bem como nos grupos controle positivo (sem tratamento), no período de 24 horas. O grupo controle negativo (sem marcação) foi empregado a fim de mostrar que não houve reação cruzada entre o anticorpo secundário (conjugado com $\mathrm{PE}$ ) e as células.

Figura 21 - Imagens adquiridas por microscopia confocal a laser, no aumento de $40 \mathrm{X}$, mostrando a marcação dos alvos Alfa e Gama, separadamente, nos grupos tratados com as concentrações de 100, 200 e $400 \mu \mathrm{M}$ de $\mathrm{NaCl}$, bem como nos grupos controle positivo (sem tratamento), no período de 24 horas. O grupo controle negativo (sem marcação) foi empregado a fim de mostrar que não houve reação cruzada entre o anticorpo secundário (conjugado com PE) e as 
células

Figura 22 - Imagens adquiridas por microscopia confocal a laser, no aumento de $40 \mathrm{X}$, mostrando a marcação dos alvos Alfa e Gama, separadamente, nos grupos tratados com as concentrações de 100, 200 e $400 \mu \mathrm{M}$ de NaF, bem como nos grupos controle positivo (sem tratamento), no período de 48 horas. O grupo controle negativo (sem marcação) foi empregado a fim de mostrar que não houve reação cruzada entre o anticorpo secundário (conjugado com PE) e as células.

Figura 23 - Imagens adquiridas por microscopia confocal a laser, no aumento de $40 \mathrm{X}$, mostrando a marcação dos alvos Alfa e Gama, separadamente, nos grupos tratados com as concentrações de 100, 200 e $400 \mu \mathrm{M}$ de $\mathrm{NaCl}$, bem como nos grupos controle positivo (sem tratamento), no período de 48 horas. O grupo controle negativo (sem marcação) foi empregado a fim de mostrar que não houve reação cruzada entre o anticorpo secundário (conjugado com PE) e as células. 
Figura 24 - Imagens dos grupos experimentais tratados com $\mathrm{NaF}$ e grupo controle adquiridas no aumento de $60 \mathrm{X}$ por microscopia confocal a laser, nos períodos de 24 e 48 horas, e gráfico de colunas mostrando a intensidade da marcação do alvo subunidade Alfa nos mesmos períodos e grupos experimentais.

Figura 25 - Imagens dos grupos experimentais tratados com $\mathrm{NaF}$ e grupo controle adquiridas no aumento de 60X por microscopia confocal a laser, nos períodos de 24 e 48 horas, e gráfico de colunas mostrando a intensidade da marcação do alvo subunidade Gama nos mesmos períodos e grupos experimentais.

Figura 26 - Imagens dos grupos experimentais tratados com $\mathrm{NaCl}$ e grupo controle adquiridas no aumento de 60X por microscopia confocal a laser, nos períodos de 24 e 48 horas, e gráfico de colunas mostrando a intensidade da marcação do alvo subunidade Alfa nos mesmos períodos e grupos experimentais

Figura 27 - - Imagens dos grupos experimentais tratados com $\mathrm{NaCl}$ e grupo controle adquiridas no aumento de 60X por microscopia confocal a laser, nos períodos de 24 e 48 horas, e gráfico de colunas mostrando a intensidade da marcação do alvo subunidade Gama nos mesmos períodos e grupos experimentais.

Figura 28 - Efeito das concentraçoes 100, 200 e $400 \mu \mathrm{M}$ de NaF na expressão gênica de Scnn1a em células epiteliais renais M-1. Letras diferentes representam diferenças estatísticas em relação ao grupo controle

Figura 29 - Efeito das concentraçoes 100, 200 e $400 \mu \mathrm{M}$ de NaF na expressão gênica de Scnn1b em células epiteliais renais $M-1$. Letras diferentes representam diferenças estatísticas em relação ao grupo controle.

Figura 30 - Efeito das concentraçoes 100, 200 e $400 \mu \mathrm{M}$ de NaF na expressão gênica de Scnn1g em células epiteliais renais M-1. Letras diferentes representam diferenças estatísticas em relação ao grupo controle. 


\section{LISTA DE ABREVIATURA E SIGLAS}

ANOVA - Análise de Variância

ATCC - American Type Culture Collection

BSA - Bovine Serum Albumin

$\mathrm{cm}^{2}$ - Centímetro Quadrado

$\mathrm{CO}_{2}-$ Dióxido de Carbono

CV - Cristal violeta

DMEM F-12 - Dulbecco's Modified Eagle's Medium: Nutrient Mixture F-12

DMSO - Dimetilsulfóxido

DO - Densidade óptica

EDTA - Ácido Etilenodiamino Tetra-Acético

$\mathrm{ENaC}$ - Canal de Sódio Epitelial

F - Flúor

$\mathrm{J}-$ Joules

$\mathrm{J} / \mathrm{cm}^{2}$ - Joules por centímetro quadrado

M - Molar

M -1 - linhagem celular epitelial imortalizada de rim

MEM - Minimum Essential Medium Eagle

mg - Miligrama

$\mathrm{ml}$ - Mililitro

$\mathrm{mM}$ - Milimolar

MTT - Brometo de 3-(4,5-dimetiltiazol-2-yl)-2,5-difeniltetrazólio

$\mathrm{Na}^{+}$- Sódio

$\mathrm{NaF}$ - Fluoreto de Sódio

$\mathrm{NaCl}$ - Cloreto de Sódio

$\mathrm{mW}$ - Miliwatts

nm - Nanômetro

OMS - Organização Mundial da saúde

PBS - Phosphate Buffered Saline

PE - Phycoerythrin

$\mathrm{pH}$ - potencial hidrogeniônico

RPM - Rotações por minuto 
RT-PCR em tempo real - Transcrição Reversa da Reação em Cadeia da Polimerase em tempo real

SFB - Soro fetal bovino

TA - Temperatura ambiente

$\mathrm{W} / \mathrm{cm}^{2}$ - Watts por centímetro quadrado

$\mu \mathrm{g}$ - Micrograma

$\mu \mathrm{L}-$ Microlitro

${ }^{\circ} \mathrm{C}$ - grau Celsius 


\section{LISTA DE SÍMBOLOS}

$\alpha-$ Alfa

$\beta$ - Beta

y - Gama

$\delta$ - Delta

$\%$ - por cento 


\section{SUMÁRIO}

1 INTRODUÇÃO

2 REVISÃO DE LITERATURA 35

$\begin{array}{lll}2.1 & \text { Fisiologia Renal } & 35\end{array}$

$2.2 \quad$ Canal de Sódio Epitelial $(\mathrm{ENaC}) \quad 42$

2.3 Considerações gerais sobre o fluoreto 45

$2.4 \quad$ Metabolismo do Fluoreto 48

$\begin{array}{lll}2.5 & \text { Toxicidade do Fluoreto } & 51\end{array}$

3 PROPOSIÇÃO

4 MATERIAL E MÉTODOS 63

$\begin{array}{lll}4.1 & \text { Cultura Celular } & 63\end{array}$

4.2 Tratamento com $\mathrm{NaF}$ e $\mathrm{NaCl}$ e ensaios de viabilidade 64

$\begin{array}{lll}\text { 4.2.1 Redução do MTT } & 67\end{array}$

$\begin{array}{lll}\text { 4.2.2 Cristal Violeta } & 68\end{array}$

$\begin{array}{lll}4.3 & \text { Imunofluorescência } & 69\end{array}$

4.4 Aquisição das imagens e quantificação da fluorescência 71

$\begin{array}{lll}4.5 & \text { Coleta das amostras para RT-PCR } & 72\end{array}$

$\begin{array}{lll}4.6 & \text { RT-PCR } & 73\end{array}$

$\begin{array}{lll}4.7 & \text { Análise Estatística } & 75\end{array}$

$\begin{array}{lll}5 & \text { RESULTADOS } & 79\end{array}$

$\begin{array}{lll}5.1 & \text { Ensaios de viabilidade celular } & 79\end{array}$ 
$\begin{array}{llr}5.1 .2 & \text { Cristal Violeta } & 85\end{array}$

$\begin{array}{lll}5.2 & \text { Imunofluorescência } & 91\end{array}$

$\begin{array}{lll}5.3 & \text { RT-PCR } & 100\end{array}$

5.3.1 Efeito das diferentes concentrações de NaF na expressão gênica da subunidade Alfa (Scnn1a) do Canal de Sódio Epitelial 100 subunidade Beta (Scnn1b) do Canal de Sódio Epitelial 100

5.3.3 Efeito das diferentes concentrações de $\mathrm{NaF}$ na expressão gênica da subunidade Gama (Scnn1g) do Canal de Sódio Epitelial 102

6 DISCUSSÃO 107

$7 \quad$ CONCLUSÕES 113

$\begin{array}{ll}\text { REFERENNCIAS } & 117\end{array}$

$\begin{array}{ll}\text { ANEXOS } & 129\end{array}$ 

1 Introdução 



\section{INTRODUÇÃO}

O fluoreto (F) é comumente utilizado em odontologia para a prevenção da cárie dentária, apesar de seus efeitos terapêuticos envolvidos na redução da incidência da cárie, quando a exposição a este composto é feita de maneira inadequada (tanto em dose crônica como aguda) pode causar reações indesejáveis (WHITFORD, 1996). Embora a água seja frequentemente a principal fonte de ingestão, o flúor também é adicionado aos dentifrícios, além de estar presente em alimentos e bebidas como chás. Como resultado as populações estão sendo expostas ao $\mathrm{F}$ por meio de veículos tópicos e sistêmicos (BUZALAF; WHITFORD, 2011).

Estudos recentes têm buscado um entendimento de seus efeitos fisiológicos e patológicos, uma vez que, tanto a exposição em curto prazo a doses elevadas, quanto a exposição crônica a baixas doses de $\mathrm{F}$ podem causar toxicidade. O efeito mais comum ligado á forma crônica é a fluorose dentária, que pode ocorrer com uma ingestão diária de $\mathrm{F}$ acima de $0,1 \mathrm{mg} / \mathrm{Kg}$ peso corporal durante vários meses ou anos (WHITFORD, 1996).

A intoxicação aguda de $\mathrm{F}$ geralmente acontece com exposições superiores a dose de $5 \mathrm{mg} / \mathrm{Kg}$ de peso corporal. Esta dose é conhecida como dose tóxica provável (DTP), e os sintomas de intoxicação aguda variam desde náuseas e vômitos, sintomas de ordem neurológica como espasmos até a morte. Por conseguinte, os níveis ideais para a ingestão de $\mathrm{F}$ são de 0,05 e $0,07 \mathrm{mg} / \mathrm{kg}$ peso corporal/dia (BUZALAF, CURY, WHITFORD, 2001; BUZALAF; WHITFORD, 2011; WHITFORD; PASHLEY, 1984; OMS, 2006).

A toxicidade do $\mathrm{F}$ está estritamente relacionada com o seu metabolismo, após a ingestão, o F é absorvido pelo estômago e intestino, seguido por uma rápida distribuição pelos tecidos. As proporções de concentração tecido/plasma nos tecidos moles variam amplamente, com uma proporção especialmente elevada no rim, tornando-os particularmente vulneráveis à toxicidade do F (WHITFORD, 1996). Os rins são órgãos essenciais para o equilíbrio do $F$, uma vez que sua remoção é feita por eles, por um processo que (semelhante à sua absorção e distribuição) é dependente do pH (BUZALAF; WHITFORD, 2011; WHITFORD, 1994). 
O F é transportado através das membranas biológicas, principalmente como $\mathrm{HF}$, forma não dissociada, que se difunde mais facilmente do que os íons $\mathrm{F}^{-}$ entre as bicamadas lipídicas (WHITFORD, 1996).

De fato, o coeficiente de permeabilidade do HF é 1 milhão de vezes maior do que o do íon $\mathrm{F}^{-}$(GUTKNECHT E WALTER, 1981). À medida que o valor do $\mathrm{pH}$ decai, há aumento da concentração do $\mathrm{HF}$, enquanto que a concentração de íons $\mathrm{F}$ aumenta quando ocorre aumento do pH (WHITFORD, 1996). Consequentemente, após a entrada de $\mathrm{F}$ nos túbulos renais, sua reabsorção é significativamente afetada por variações do $\mathrm{pH}$ tubular (WHITFORD, 1994). A excreção urinária do $\mathrm{F}$ também é criticamente dependente da taxa de filtração glomerular (TFG) (EKSTRAND, 1996).

Por esta razão, reduções na TFG associadas a disfunção renal crônica ou envelhecimento resultam em menor excreção de $\mathrm{F}$ e aumento dos níveis plasmáticos de $\mathrm{F}$, desta maneira, como a excreção de $\mathrm{F}$ depende da função renal, a função renal pode, por sua vez, ser afetada pelo F (DOTE et al., 2000).

A eliminação e toxicocinética do $F$ são nitidamente influenciadas pela lesão renal induzida por $\mathrm{F}$ (DOTE et al., 2000). Em particular, sabe-se que o $\mathrm{F}$ pode causar disfunção renal relacionada com a dose, associada à poliúria, devido à diminuição da capacidade de concentração de urina (CITTANOVA et al., 1996). Deste modo, existe a possibilidade de um ciclo vicioso, em que o declínio da função renal leva a uma maior nefrotoxicidade do $F$, e assim por diante. Os efeitos nefrotóxicos do $F$ envolvem comprometimento da função celular, tanto no ramo ascendente da alça de Henle como no ducto coletor, e foi demonstrado, em modelos de ratos com nefrotoxicidade pela exposição aguda ao $\mathrm{F}$, que a parte distal do néfron foi mais susceptível a danos que qualquer outra estrutura tubular (CITTANOVA et al., 1996; DOTE et al., 2000).

As células renais estão expostas as concentrações de $\mathrm{F}$ relativamente altas e mostram um gradiente progressivo de concentração, assim as porções dos rins, responsáveis pela habilidade de concentrar a urina e conservar a água no organismo, como a alça de Henle e ductos coletores, são expostas as concentrações mais elevadas de $F$ nos rins (WHITFORD, 1996). A utilização de modelos experimentais demonstrou que a toxicidade renal do $F$ ocorre, principalmente, pela exposição ao fluoreto de sódio ( $\mathrm{NaF}$ ), e a nefrotoxicidade do $\mathrm{F}$ 


\section{Introdução}

resulta tanto de uma exposição aguda quanto crônica (BARBIER et al., 2010; DOTE et al., 2000).

Mudanças estruturais marcantes têm sido relatadas em rins de animais com intoxicação crônica ou aguda por $F$, tais como hemorragia, hiperemia glomerular e medular, alterações inflamatórias, destruição tubular e edema intersticial (KOBAYASHI, 2009).

Apesar de vários relatos na literatura sobre a toxicidade do $F$, pouco se sabe sobre os mecanismos celulares e moleculares responsáveis por esse efeito. Já é descrito que o $\mathrm{F}$ em concentrações na ordem de $\mu \mathrm{M}$ induz apoptose de várias linhagens celulares, bem como induz alteração da resposta imunológica (ANURADHA et al., 2001; REFSNES et al., 2001; REFSNES et al., 2003; WANG et al., 2004).

Acredita-se que pelo menos três classes de proteínas envolvidas em pontos chave na transdução de sinal sejam afetadas pelo $\mathrm{F}$ : proteínas $\mathrm{G}$, proteínas quinases e proteínas fosfatases (REFSNES et al., 2003).

Análises proteômicas tem revelado que a exposição a baixos níveis de $\mathrm{F}$ provoca alterações nos níveis de expressão de uma variedade de proteínas em camundongos da linhagem 129P3/J e A/J, a maioria das quais se enquadram na categoria de proteínas "house-keeping", como por exemplo, o aumento da expressão da proteína serina/treonina fosfatase (PP1), que regula a função de muitas proteínas, incluindo canais e transportadores, tais como o cotransportador $\mathrm{Na}^{+}-\mathrm{K}^{+}-2 \mathrm{Cl}$ (NKCC1), os canais Cystic Fibrosis Transmembrane Conductance Regulator (CFTR) e o canal de $\mathrm{Na}^{+}$epitelial (ENaC) (CARVALHO et al., 2013; BECCHETTI et al., 2002; DARMAN et al., 2001; MORI et al., 2001). Além de alterar a expressão do cofator de regulação do trocador $\mathrm{Na}^{+} / \mathrm{H}^{+}, \mathrm{NHE}-\mathrm{RF} 3$ (PDZK1), que foi significativamente reduzida nos rins dos ratos da linhagem 129P3/J, estes efeitos poderiam influenciar a reabsorção de íons ou então resultar em reduções na eficiência do transporte iônico (CARVALHO et al., 2013).

Os efeitos diretos do $\mathrm{F}$ em proteínas de transporte, incluindo a bomba $\mathrm{Na}^{+} / \mathrm{K}^{+}$-ATPase, o canal CFTR e os transportadores de cálcio, já foram descritos (BARBIER et al., 2010). No entanto, o conhecimento dos efeitos do F sobre transportadores como o canal de sódio epitelial (ENaC), localizados em células 
epiteliais de rim, é incompleto, em grande parte devido à complexidade e diversidade das interações fisiológicas envolvidas.

O canal de sódio epitelial (ENaC) está localizado na membrana apical das células epiteliais dos rins, onde a sua principal função é transportar os íons $\mathrm{Na}^{+}$do lúmen para fora da célula, desta maneira a atividade do ENaC é um fator limitante para a reabsorção de sódio e água no organismo. Diferentes respostas, incluindo fatores extrínsecos e intrínsecos são capazes de modular a expressão e as propriedades deste canal. O canal é composto por três subunidades de homólogas: alfa, beta e gama. Diversas vias são importantes para a regulação deste canal, essas vias podem controlar ou interferir em um ou mais modos funcionais de regulação que incluem: a expressão/síntese do canal, o tráfico intracelular, e propriedades individuais do canal, como sua capacidade de abertura (Bhalla; Hallows, 2008). A importância fisiológica deste canal é ilustrada por mutações naturais ou condições que causam aumento ou diminuição da atividade de ENaC. Por isso entender a regulação desse canal é fundamental para a compreensão de vários fenômenos clínicos, incluindo a fisiologia normal, doenças como hipertensão e fibrose cística e também a ação de substâncias químicas sobre estes canais (O'Neil et al., 2008).

Neste trabalho, investigamos o efeito de concentrações de $F$, que podem ser encontradas no néfron durante a fluorose dentária, sobre a viabilidade de células epiteliais renais $(\mathrm{M}-1)$, bem como sua influência nos transportadores de sódio ENaC localizados na membrana de celular. 
2 Revisão de Literatura 



\section{REVISÃO DE LITERATURA}

\subsection{Fisiologia Renal}

O rim é um órgão par abdominal localizado acima da cintura posteriormente ao peritônio parietal (retroperitoneal) e situa-se a esquerda e a direita da coluna vertebral, onde são parcialmente protegidos pelo décimo primeiro e décimo segundo pares de costelas, apresenta duas extremidades denominadas polos, sobre o polo superior situam-se a glândula supra-renal (DANGELO, FANTTINI, 2006). Diversas são as funções desempenhadas pelos rins, dentre elas: regulação do volume do líquido extracelular e da pressão sanguínea, eliminação de substâncias tóxicas provindas do metabolismo, ou seja, a excreção de subprodutos metabólicos, toxinas, fármacos entre outros, regulação da osmolaridade mantendo a concentração de eletrólitos e solutos equilibrada e constante para a homeostase, regulação do $\mathrm{pH}$ do plasma por meio do equilíbrio entre íons hidrogênio e bicarbonato, produção de hormônios como a eritropoetina e renina e por fim manutenção do equilíbrio iônico (TORTORA, 2000).

Ambos os rins são recobertos por uma cápsula fibrosa e em seu interior há uma depressão denominada hilo, do qual o ureter deixa o rim, e os vasos sanguíneos linfáticos e nervos entram e saem. Por meio das artérias renais, aproximadamente 1.200 a 2.000 litros de sangue chegam aos rins, recebendo uma alta taxa de fluxo sanguíneo, cerca de 20 a 25\% do débito cardíaco (BLODGETT, KOTHINTI, KAMYSHKO, PETERING, KUMAR, TABATABAI, 1994).

No interior dos rins (Figura 1) cada ureter forma estruturas denominadas cálices que se ramificam e formam os cálices menores. Os cálices atuam como taças coletoras da urina formada e encaixam-se sobre, especificamente, as papilas presentes no ápice de estruturas presentes na camada interna do rim denominadas pirâmides renais que constituem a medula do rim. Na camada mais externa encontra-se o córtex que se justapõe sobre o tecido medular, ambos os tecidos são formados pelo arranjo organizado de túbulos microscópicos chamados de néfrons e por vasos sanguíneos (EATON, POOLER, 2016; SILVERTHORN, 2011). 


\section{Revisão de Literatura}

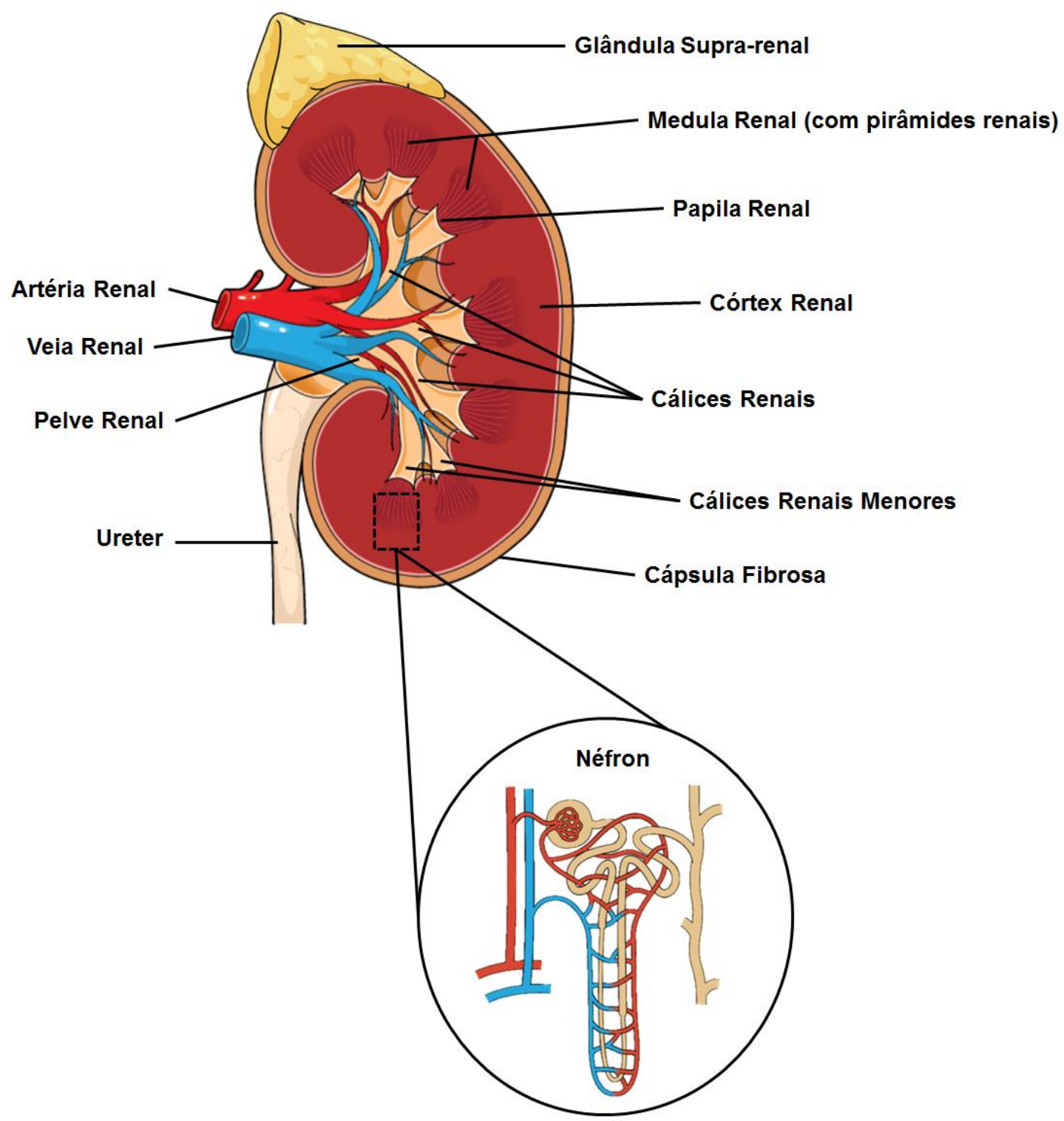

Figura 1 - Representação esquemática das principais estruturas do rim.

O néfron é a unidade funcional do rim e em cada rim cerca de 1 milhão de néfrons são responsáveis pela formação da urina. $O$ néfron é dividido em segmentos intimamente associados com vasos sanguíneos especializados, que formam um conjunto de elementos vasculares (capilares glomerulares) e tubulares (cápsula de Bowman, túbulo proximal, alça de Henle, túbulo distal e ducto coletor), onde acontecerá os processos de filtração, reabsorção e secreção (BLODGETT, KOTHINTI, KAMYSHKO, PETERING, KUMAR, TABATABAI, 1994; SILVERTHORN, 2011). O primeiro processo (filtração) ocorre no corpúsculo renal, onde o plasma sanguíneo presente nos capilares glomerulares (glomérulo) é filtrado na cápsula de Bowman, apesar de não ser um processo seletivo, em situações fisiológicas 
normais, células e proteínas plasmáticas não passam para dentro da cápsula de Bowman. O filtrado resultante da filtração glomerular vai ter a mesma concentração osmótica do plasma, no entanto, à medida que flui da cápsula de Bowman pelas várias porções do túbulo, sua composição é alterada pela reabsorção e secreção tubular, provocando mudanças na osmolaridade. Desta maneira, a diferença osmótica é um fator que ocasionará a reabsorção de outras substâncias (EATON, POOLER, 2003; TORTORA, 2000).

A reabsorção da água é dependente da reabsorção de sódio, pois à medida que o sódio é reabsorvido o filtrado glomerular fica menos concentrado que o interior das células, ocasionando mudanças na osmolaridade, fazendo com que a água passe do meio com menor concentração de soluto para o mais concentrado (osmose). Desta maneira, a reabsorção de sódio é fundamental para a reabsorção de outras substâncias como cloreto e ureia, visto que a passagem de água para o meio com maior concentração de sódio, implicará no aumento da concentração dessas substâncias (EATON, POOLER, 2003; SILVERTHORN, 2011).

O transporte de sódio ocorre por diferentes maneiras como o transporte passivo, o transporte ativo e por meio de transportadores como canais e proteínas, dentro da célula é regulado graças à bomba de sódio e potássio. Os sítios alvo responsáveis pela regulação do sódio são os canais de sódio epitelial $(\mathrm{ENaC})$ que estão localizados na membrana apical de células epiteliais nos túbulos renais distal (DANGELO, FANTTINI, 2006; RAFF, STRANG, WIDMAIER, 2013).

$O$ processo de reabsorção ocorre em proporções diferentes nos segmentos do néfron, a reabsorção de sódio vai acontecer principalmente no túbulo contorcido proximal (67-80\%) devido a características especiais nas células epiteliais ali presentes. Estas células são metabolicamente ativas, desta maneira, apresentam mitocôndrias em abundância e participam do processo de geração de energia para a realização do transporte ativo de íons, além disso, estas células apresentam grande quantidade de transportadores em suas membranas (RAFF, STRANG, WIDMAIER, 2013). A parte distal do néfron será responsável por reabsorver menos de $10 \%$ de sódio, no entanto, a sensibilidade que esta região tem a hormônios e outros fatores são vitais no controle do nível final de sódio na urina (KOKKO, 1987). 
Os rins são responsáveis pela maior parte da excreção de sódio e sua regulação é fundamental para o controle do nível de sódio em todo o corpo e na homeostase dos fluídos (EDELHEIT; HANUKOGLU; DASCAL, 2011).

A regulação do sódio no sangue ocorre por meio de vias endócrinas (Figura 3), onde os hormônios vasopressina e aldosterona desempenham papéis fundamentais no ajuste do sódio e na reabsorção na parte distal do néfron (STARUSCHENKO, 2012).

O controle fisiológico da aldosterona se dá quando a concentração extracelular de $\mathrm{K}^{+}$está aumentada e pressão sanguínea diminuída. O decréscimo da pressão sanguínea faz com que as células da mácula densa percebam modificações na concentração sódio do filtrado glomerular e transmitam sinalização parácrina para as células justaglomerulares, que por sua vez, em resposta a informação começa a produzir uma enzima chamada renina (RIBEIRO, PLAVNIK, 2007).

O aparelho justaglomerular é constituído por três tipos celulares: células da mácula densa, localizadas na junção entre a parte reta, a parte contorcida do túbulo distal e a parede adjacente ao corpúsculo renal, células justaglomerulares, localizadas na porção dos componentes vasculares, mais especificamente, na túnica média das arteríolas aferente e eferente, e células mesangiais extraglomerulares situadas em uma região triangular formada pela mácula densa, arteríolas aferente e eferente e células mesangiais (RAFF, STRANG, WIDMAIER, 2013).

No sangue a renina converte o angiotensinogênio (proteína produzida pelo fígado) em angiotensina I que é posteriormente convertida pela enzima ECA, encontrada abundantemente nas células endoteliais do pulmão, em angiotensina II (EATON, POOLER, 2003).

A angiotensina II é um hormônio que desempenha um papel central na homeostase cardiovascular, dentre suas principais funções, uma delas é atuar como agonista vasoativo através de receptores AT1 e induzir a constrição não somente dos vasos sanguíneos, mas também, das arteríolas especialmente a arteríola eferente (TIMMERMANS et al., 1993; KIM, IWAO, 200). Além disso, estimula a glândula supra-renal a secretar aldosterona, que por sua vez, age no ducto coletor e nos túbulos distais aumentando a reabsorção de sódio (RAFF, STRANG, WIDMAIER, 2013). 
O mecanismo de ação da aldosterona se faz por meio de sua ligação a receptores MR, das células epiteliais ali presentes, que iniciam a transcrição de dois genes aumentando a expressão de proteínas transportadoras (VIENGCHAREUN et al., 2001). Esses genes codificam as subunidades proteicas da bomba de sódio e potássio $\left(\mathrm{Na}^{+} / \mathrm{K}^{+}\right.$ATPase) e do canal de sódio epitelial (ENaC), localizadas na superfície celular basolateral e membrana apical respectivamente (GARTHY, PALMER, 1997).

O aumento da atividade nas bombas de sódio e potássio faz com que o potássio, presente em nível extracelular elevado, seja transportado facilmente para dentro das células tubulares estimulando a reabsorção de sódio, este fará com que a água siga seu movimento via osmose, estabilizando o volume plasmático e aumentando consequentemente a pressão arterial (FERAILLE, DOUCET, 2001).

Por outro aldo, o aumento de atividade nos canais de sódio epitelial (ENaC), induzida pela aldosterona, fará com que o sódio restante passe facilmente pelos canais na parte lumial da célula e seja imediatamente jogado para o sangue através da bomba de sódio e potássio levando a água juntamente que é também reabsorvida (Figura 2) (JOHANNESSON et al., 2000).

A angiotensina II também atua diretamente nos túbulos proximais e alça de Henle, no sistema nervoso central é capaz de aumentar a produção de vasopressina (hormônio antidiurético), estas ações múltiplas produzem retenção acentuada de sódio pelos rins. O ADH (antidiuretic hormone) ou vasopressina age nas células dos túbulos distal e coletor aumentando a permeabilidade deste epitélio à água por meio do aumento da atividade de aquaporinas que promovem a reabsorção de água livre de solutos (STOCKAND, 2010; TANAKA et al., 2004). A água será retida e sua excreção será diminuída de forma a manter a volemia e a pressão arterial (HALL, 2011; SILVERTHORN, 2011). 


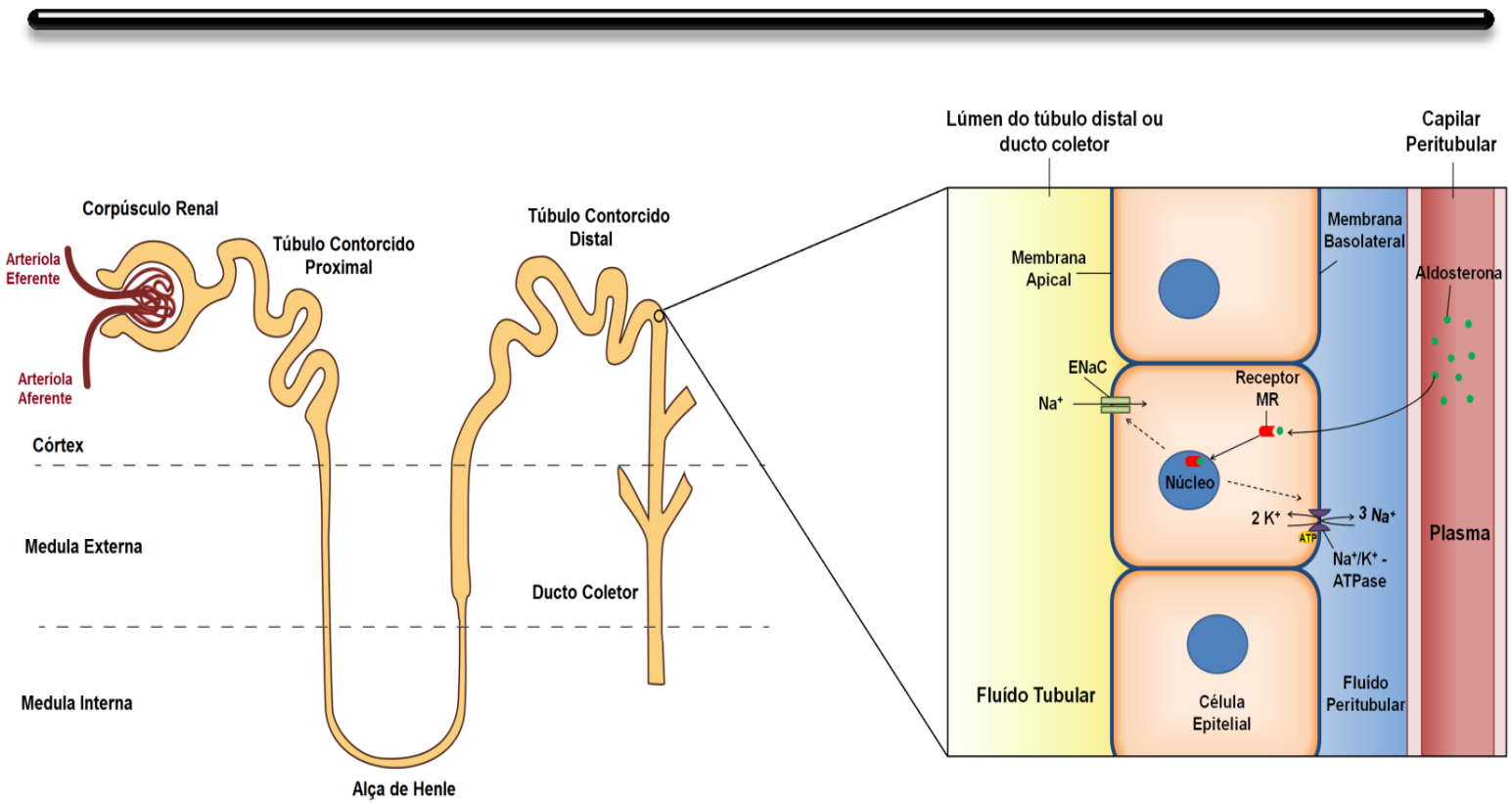

Figura 2 - Principais estruturas do néfron e mecanismo de ação da aldosterona sobre o canal de sódio epitelial e a bomba de sódio e potássio presentes na membrana apical e basolateral, respectivamente, das células epiteliais do túbulo contorcido distal.

Tendo em vista a capacidade do rim de eliminar substâncias provindas do metabolismo e outras, como fármacos e toxinas, este apresenta certa vulnerabilidade a determinadas substâncias, podendo sofrer com danos a nível glomerular, tubular, intersticial e vascular. Essas substâncias poderão atuar causando a diminuição do fluxo sanguíneo renal, interagindo diretamente com a membrana celular ou por meio da geração de toxinas intracelulares (BRADY et al., 2000; PARMAR, 2002). 


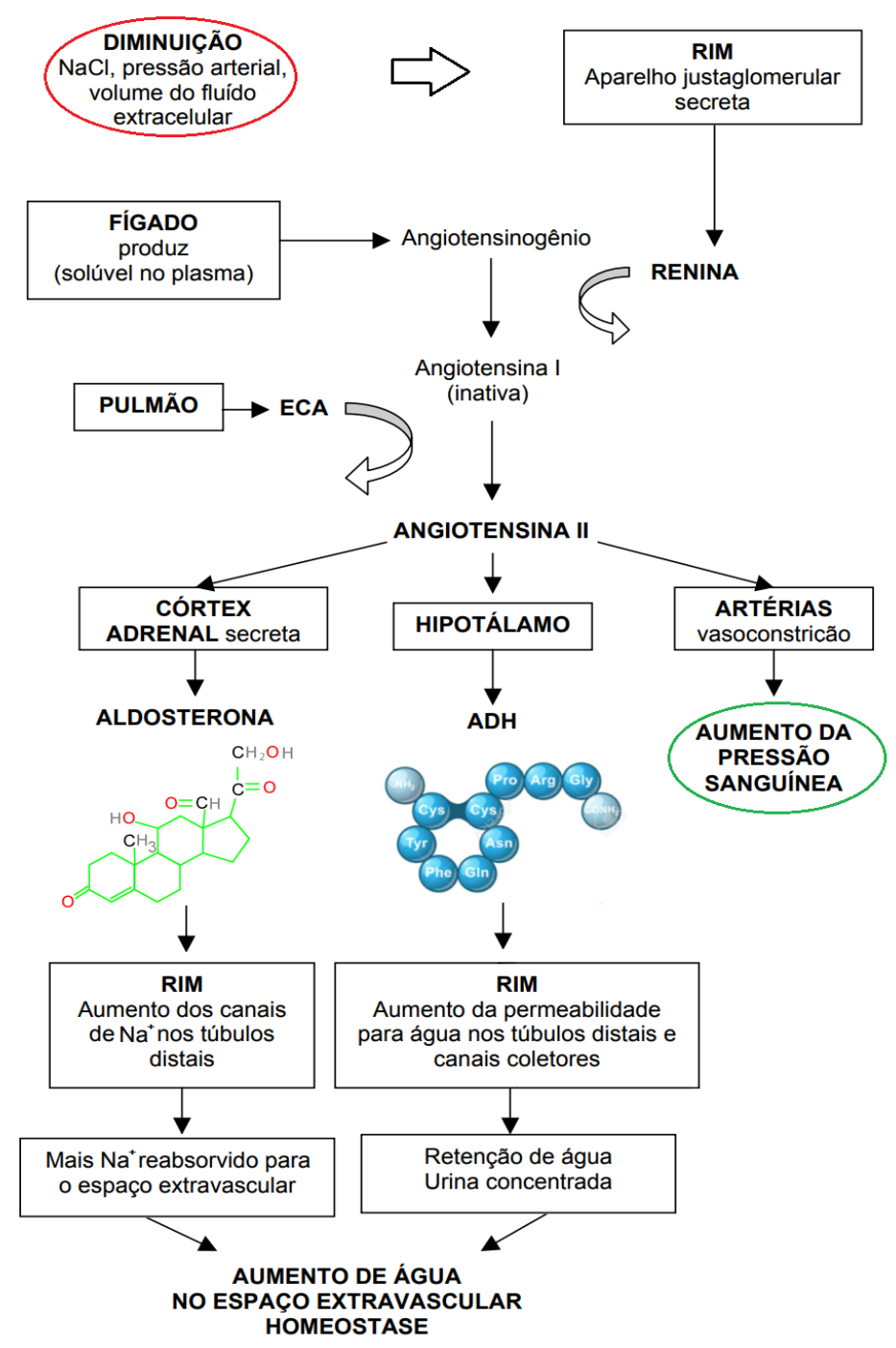

Figura 3 - Resumo esquemático da regulação endócrina para a manutenção do equilíbrio hidroeletrolítico.

Os rins são órgãos essenciais para o equilíbrio do fluoreto uma vez que são sua principal via de excreção, e se comparado com outros órgãos, as concentrações de $\mathrm{F}$ nas células renais são 4 vezes mais elevadas, o que aumenta a sua toxicidade neste órgão (Figura 4) (BUZALAF \& WHITFORD, 2011). 


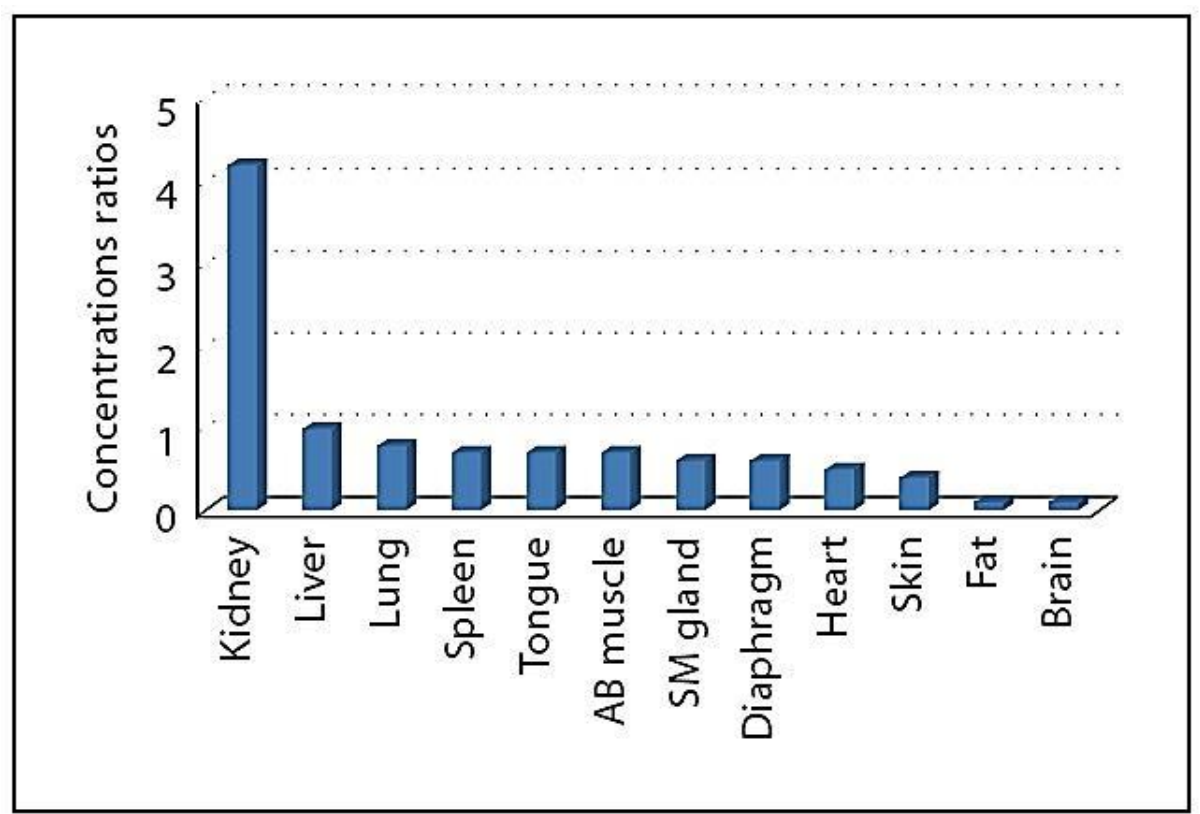

Fonte: Adaptado de: BUZALAF; WHITFORD, 2011.

Figura 4 - Proporções de concentração tecido/plasma de fluoreto em tecidos moles de ratos.

\subsection{Canal de Sódio Epitelial (ENaC)}

O canal de sódio epitelial (ENaC) está localizado na membrana apical das células epiteliais dos rins, onde a sua principal função é transportar os íons $\mathrm{Na}^{+}$do lúmen para fora a célula. ENaC pertence à superfamília de canais iônicos ENaC-Deg (canais de sódio epiteliais - degenerinas). As proteínas desta superfamília apresentam um alto grau de heterogeneidade e podem ser expressas em diferentes tipos celulares e cumprir múltiplas funções em diferentes espécies (STEWART et al., 2011, ROSA et al., 2000).

Todos os membros da superfamília ENaC-Deg compartilham características estruturais em comum que são a presença de duas regiões hidrofóbicas que estão incorporados na membrana e funcionam como dois segmentos transmembrana (TM), denominados TM1 e TM2. No formato disposto na membrana os extremos C (carboxi) e N (amino) terminal são intracelulares e por fim um grande loop extracelular que conecta os segmentos TM, que compreende cerca de $70 \%$ dos aminoácidos de cada subunidade e apresenta resíduos de cisteína altamente conservados (Figura 5). (CANESSA et al., 1994a; RENARD et al., 1994; SNYDER et al., 1994; LAl et al., 1996). 


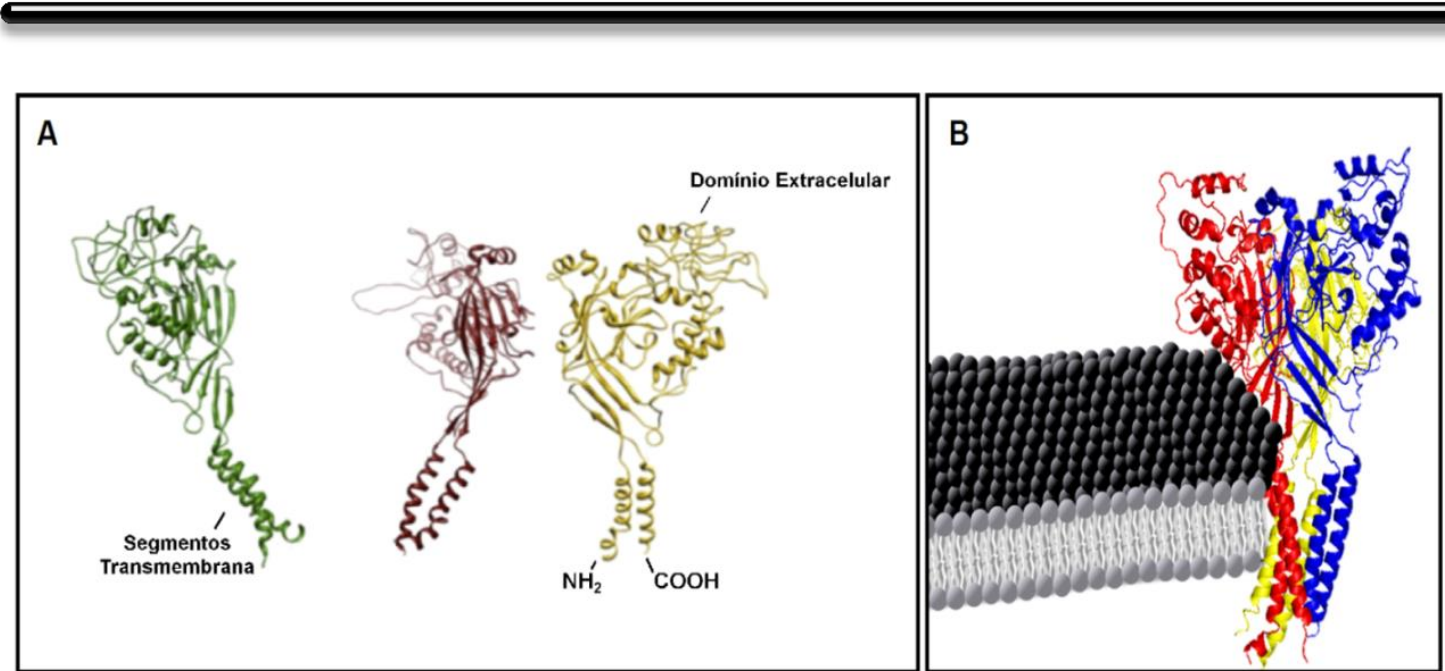

Fonte: Adaptado de: SCHILD, 2010.

Figura 5 - (A) Modelos de homologia de subunidades ENaC com base na estrutura cristalina do canal ASIC: $\alpha \mathrm{ENaC}$ (verde), $\beta \mathrm{ENaC}$ (vermelho) e y ENaC (amarelo). (B) Configuração espacial das três subunidades unidas formando o canal de sódio epitelial $(\mathrm{ENaC})$ na membrana celular.

O canal é composto por três subunidades de glicoproteínas homólogas: alfa, beta e gama e as três subunidades homólogas se agrupam para formar o canal de sódio epitelial, no entanto, existem controvérsias sobre a estequiometria das subunidades, pois, no passado foi proposto que ENaC fosse montada a partir de quatro ou oito a nove subunidades e embora a estrutura de ENaC não seja conhecida, a forte hidrofobicidade dos segmentos TM e uma recente publicação da estrutura cristalina de $A S I C 1 a$ sugere que $E N a C$ possa ser um trímero (BACONGUIS et al., 2014; JASTI et al., 2007).

Uma quarta subunidade, delta $\mathrm{ENaC}$, apresenta similaridades funcionais com alfa ENaC mas seu papel fisiológico ainda não foi esclarecido (STEWART et al., 2011). A expressão das três subunidades de $\mathrm{ENaC}$ são necessárias para a atividade completa do canal, embora a expressão da subunidade alfa sozinha, ou das combinações alfa e beta, alfa e gama levam à geração de pequenas correntes também (ROTIN, KANELIS, SCHILD, 2001).

O grande domínio extracelular é essencial para a função do ENaC, mas seu papel no suporte do fluxo de íons $\mathrm{Na}^{+}$, através ou na entrada do canal, ainda não está claro. $\mathrm{O} \mathrm{N}$-terminal citosólico contém domínios que regulam o fechamento do canal e provavelmente a abertura do poro no lado citosólico. Já o C - terminal citosólico de cada subunidade contém um domínio rico em prolina envolvido em interações específicas com proteínas regulatórias (SCHILD, 2010). 
A atividade do $\mathrm{ENaC}$ é um fator limitante para a reabsorção de sódio e água no ducto coletor e túbulos distais (PETTY et al., 1981).

Nos rins, ENaC modula a quantidade de sódio no fluído extracelular, tendo um papel importante na regulação do volume e pressão sanguínea, no entanto, o transporte do sódio é dependente do número de canais localizados na membrana lumial e da frequência com que o sódio é transportado por eles (CANESSA et al., 1994; BÜSST, 2013; ROSSIER et al., 2015).

Diferentes respostas, incluindo fatores extrínsecos e intrínsecos são capazes de modular a expressão e as propriedades deste canal, ou seja, a regulação do $\mathrm{ENaC}$ ocorre em vários níveis (biofísica, transcrição, modificações póstraducionais, montagem, inserção de membrana, recuperação, reciclagem, degradação, etc.) que podem controlar ou interferir em um ou mais modos funcionais de regulação que incluem: a expressão/síntese do canal, o tráfico intracelular e propriedades individuais do canal, como sua capacidade de abertura (BHALLA; HALLOWS, 2008).

A importância fisiológica deste canal é ilustrada por mutações naturais ou condições que causam aumento ou diminuição da atividade de ENaC. Essas alterações na estrutura e função do $\mathrm{ENaC}$ foram associadas a várias doenças humanas, como na síndrome de Liddle, em que mutações nos genes que codificam ENaC alteram a expressão e o tráfico na superfície celular, levando a diminuição da atividade do canal que resulta em perda de sal e consequente hipotensão (BUTTERWORTH, 2010; CHANG et al., 1996).

Compreender os mecanismos moleculares envolvidos no tráfico de $\mathrm{ENaC}$ pode identificar outras anormalidades em sua atividade que levaria a hipertensão ou outras doenças relacionadas, como fibrose cística. Além disso, o melhor entendimento da regulação desse canal levaria compreensão de outros fenômenos clínicos, incluindo a fisiologia normal e a ação de substâncias químicas sobre estes canais (O'NEIL et al., 2008).

Diferentemente dos canais iônicos de fechamento por tensão e fechamento por ligante, que são regulados pelas mudanças rápidas na abertura e fechamento do canal, ENaC é regulada em grande parte pelos mecanismos que controlam sua expressão na superfície celular, semelhante a regulação de muitos 
receptores e transportadores. No entanto, este mecanismo sacrifica a velocidade, mas sua vantagem é a faixa dinâmica de abertura maior do canal (SNYDER, 2005).

A atividade da $\mathrm{ENaC}$ é regulada pelo sistema renina-angiotensinaaldosterona, onde a aldosterona é o principal regulador hormonal no transporte sódio e potássio $A E N a C$ é o principal objeto da sua regulamentação, e sua estimulação pela aldosterona afeta os processos de reabsorção sódio e secreção de potássio e hidrogênio (BHALLA \& HALLOWS, 2008; BÜSST, 2013; ROSSIER et al., 2015).

O mecanismo de ação da aldosterona é mediado pela sua ligação ao receptor mineralocorticoide (MR) que é expresso nas células principais epiteliais (túbulo distal e ducto coletor), MR é quase certamente o único receptor de aldosterona nas células principais. O complexo ativado aldosterona-receptor é deslocado para o núcleo, onde se liga a regiões regulatórias específicas do DNA (genes-alvo), e aumenta a expressão de genes incluindo os genes que codificam as subunidades do canal de sódio epitelial (ENaC) (BONVALENT, 1998; GOMÉZSANCHES, 2004).

A abundância de RNA mensageiro das subunidades do canal de sódio de ENaC é um importante fator e determinante da atividade do mesmo (STOKES et al., 1998; MASILAMANI et al., 1999).

$A$ atividade de $\mathrm{ENaC}$ pode ser inibida por bloqueadores farmacológicos tais como triantereno ou amilorida. A inibição de $\mathrm{ENaC}$ pela amilorida acontece em concentrações relativamente baixas, e o local de ação descrito para que aconteça a inibição é no sitio do segundo domínio TM, constituído de uma serina na subunidade alfa e uma glicina nas subunidades beta e gama. A introdução de mutações específicas nesses locais leva a uma perda profunda da eficácia da amilorida (KASHLAN ET AL., 2005; SCHILD et al., 1997).

\subsection{Considerações gerais sobre o fluoreto}

O flúor é um elemento químico descrito como $\mathrm{F}$ na tabela periódica, apresenta número atômico 9, peso atômico 19 e pertence ao grupo dos halogênios, seu nome é originário do latim fluere, que significa fluir (BUZALAF; CARDOSO, 2008; PEIXOTO, 1998). 
Possui um pequeno raio atômico que faz com que sua carga de superfície efetiva seja maior que a de outros elementos tornando-o o elemento mais reativo e eletronegativo da tabela periódica. Uma vez que sua alta eletronegatividade the confere uma considerável força de repulsão entre seus átomos, o íon fluoreto é capaz de se ligar facilmente a qualquer outro elemento (SMITH; EKSTRAND, 1996; PEIXOTO, 1998).

O flúor se difere dentre os halógenos em vários aspectos, é exclusivamente monovalente e combina-se reversivelmente com íons de hidrogênio para formar o ácido fluorídrico, tendo muitos de seus comportamentos fisiológicos explicados com base na difusibilidade deste ácido fraco (WHITFORD, 1996).

É abundantemente encontrado na natureza e existe somente em combinação com outros elementos, ou seja, devido a sua extrema reatividade não ocorre em seu estado livre. Forma compostos orgânicos e inorgânicos como compostos fluoretados que são constituintes de minerais achados no solo e em rochas como a fluorita $\left(\mathrm{CaF}_{2}\right)$, está também presente no magma e nos vapores de erupções vulcânicas. (BUZALAF; CARDOSO, 2008; EKSTRAND, 1996).

O fluoreto é geralmente encontrado nas águas subterrâneas em uma ampla gama de concentrações, entre 0,5 e 25 ppm, e ocorre naturalmente em muitos corpos d'água devido ao intemperismo de rochas fluoradas e lixiviação dessas partículas sólidas nas águas subterrâneas (ATSDR, 2003; EDMUNDS; SMEDLEY, 1996).

$\mathrm{Na}$ natureza é encontrado frequentemente na forma inorgânica estando presente nos complexos minerais, sendo $01^{\circ}$ elemento mais abundante, representando aproximadamente 0,06 - 0,09\% da crosta terrestre, já sua ocorrência em organismos biológicos está majoritariamente na casa de partes por milhão (ppm), sendo classificado como elemento traço (SMITH; EKSTRAND, 1996; WITHFORD, 1983). Em condições normais de temperatura e pressão o flúor é um elemento gasoso de coloração amarelo - pálido, foi obtido pela primeira vez por Henri Moissan, na França em 1886 (BUZALAF; CARDOSO, 2008, PEIXOTO, 1998).

Sabe-se que o flúor interage com tecidos mineralizados como os ossos e os dentes, apresenta grande capacidade de estimular a formação do tecido ósseo, em baixas doses, e possui uma reconhecida ação terapêutica sobre a cárie (FARLEY, 1983; PARNELL et al., 2009). 
A capacidade de inibição e reversão dos processos cariosos se dá pela ligação do íon $\mathrm{F}$ com fosfato de cálcio (presente no dente) formando a apatita fluoretada (ELLWOOD et al., 2008).

O estudo epidemiológico realizado por Dean em 1942 pode mostrar a correlação diretamente proporcional entre a prevalência de fluorose dentária e concentração de íon $F$ na água de consumo e a correlação inversamente proporcional, entre a presença de $\mathrm{F}$ e a prevalência da cárie. As pesquisas para a fluoretação da água de abastecimento público, como medida de controle de cárie dentária, vêm sendo estudado há muito tempo, mas apenas em 1945 descobriu-se um teor ideal de $\mathrm{F}$ na água para promover a saúde dentária. A fluoretação da água de beber é considerada uma das dez mais importantes estratégias em saúde pública do século XX (BURT; FEJERSKOV, 1996; KOZLOWSKI; PEREIRA, 2003).

Inegavelmente a fluoretação da água de abastecimento associada à utilização de dentifrícios fluoretados são eficazes na prevenção e controle da cárie, porém uma das maiores preocupações é a dificuldade de se controlar as doses individuais diárias de $\mathrm{F}$ que são ingeridas, sendo difícil estabelecer a dose ideal para ser adicionado a água (CARDOSO et al., 2003; PECKHAM; AWOFESO, 2014).

As principais fontes de exposição sistêmica ao $\mathrm{F}$ são representadas pela dieta (água e alimentos) e produtos dentais contendo F (TUBERT- JEANNIN et al., 2011).

O limite máximo de concentração de flúor na água de beber estabelecido pela Organização Mundial da Saúde (OMS) é de $1,5 \mathrm{mg} / \mathrm{L}$ e a quantidade de ingestão diária de flúor aceita como ideal para a prevenção da cárie é de 0,05 a 0,07 $\mathrm{mg} / \mathrm{Kg}$ de peso corporal, já a dose tóxica provável (DTP) é estabelecida na faixa de $5 \mathrm{mg} / \mathrm{Kg}$ peso corporal. Esta última dose poderia causar sinais e sintomas tóxicos além de requerer intervenção terapêutica e hospitalização imediata (BUZALAF; CURY; WHITFORD, 2001; OMS, 2006; WHITFORD et al., 2008).

\subsection{Metabolismo do Fluoreto}

A partir de sua ingestão o fluoreto é rapidamente absorvido pelo trato gastrointestinal, no entanto, a absorção está diretamente relacionada à acidez estomacal, uma vez que a absorção deste íon será dependente da resposta a 
diferenças de $\mathrm{pH}$ entre os compartimentos de fluido corporal adjacentes, e além disso, seu transporte nas membranas biológicas dependerá de sua forma iônica ou não (WHITFORD, 1996). No ambiente ácido da cavidade estomacal o fluoreto é convertido em HF, que apresenta um pKa de 3,4 o que significa que em um pH de 3,4 metade do fluoreto vai estar na forma não iônica (HF) e a outra metade vai estar na forma iônica ( $F-$-). Portanto, se $\circ \mathrm{pH}$ do ambiente for menor que 3,4 a concentração de HF irá aumentar, e se o inverso acontecer e o meio ficar mais alcalino ( $\mathrm{pH}$ acima de 3,4) a concentração de F- aumenta, visto que, o coeficiente de permeabilidade das membranas celulares para HF é muito maior do que o de F- , HF atravessa a mucosa gástrica por difusão passiva sem ajuda de transportadores, indo do meio mais ácido para o mais alcalino (BUZALAF; WHITFORD, 2011).

Aproximadamente 80 a $90 \%$ do fluoreto vai ser absorvido desta maneira e o restante será absorvido pelo intestino delgado por um mecanismo independente de $\mathrm{pH}$, através de canais existentes nas junções celulares (tight junctions). O fluoreto que não for absorvido será excretado pelas fezes (WHITFORD, 1996). A absorção de $\mathrm{F}$ pode ser afetada pela dieta, por alimentos que interage com o $\mathrm{F}$ e bebidas que contenham cálcio, alumínio e magnésio (WHITFORD, 1996).

O F distribui-se rapidamente pelo organismo, atingindo seu pico no plasma após 20 a 60 minutos, seguido de um rápido declínio como resultado da absorção deste elemento por tecidos calcificados e excreção de urina (EKSTRAND, 1996; WHITFORD, 1996). Do plasma uma pequena parte de $F$ é distribuído para tecidos moles e fluidos corporais especializados, a maioria é absorvido por tecidos mineralizados e aproximadamente $50 \%$ do flúor absorvido diariamente por jovens e adultos saudáveis associa-se com os tecidos calcificados, em 24 horas, e a outra metade é excretado na urina (BUZALAF; CARDOSO, 2008; EKSTRAND, 1996; WHITFORD, 1996).

Aproximadamente $99 \%$ do $\mathrm{F}$ retido no organismo está associado com os tecidos mineralizados (ossos, dentina, esmalte). Nos tecidos mineralizados F é incorporado reversivelmente, nas regiões mais profundas do tecido ósseo, onde durante a remodelação óssea é liberado e volta ao plasma. Em contrapartida, F presente nos tecidos calcificados, localizado nos cristalitos da superfície óssea, não está ligado de maneira irreversível (WHITFORD, 1996). 
O restante de fluoreto que não foi retido no organismo será eliminado pelos rins, cerca de $50 \%$ do $\mathrm{F}$ absorvido pelo trato gastrointestinal é diariamente excretado na urina de adultos saudáveis (BUZALAF; WHITFORD, 2011).

O flúor é livremente filtrado pelo glomérulo e sofre um grau variável de reabsorção tubular proximal, diretamente relacionado ao $\mathrm{pH}$ do filtrado glomerular (WHITFORD, 1994). Após o $\mathrm{F}$ entrar nos túbulos renais, uma quantidade variável (de 10 a 90\%) é reabsorvida para a circulação sistêmica, dependendo do $\mathrm{pH}$ urinário, porque a migração transmembranar ocorre por meio da difusão de $\mathrm{HF}$ (WHITFORD et al., 1976).

Quando o pH do fluído tubular (urina) é relativamente alto, a quantidade de flúor como HF é menor, enquanto a de F- é maior, então, uma baixa concentração de $\mathrm{F}$ vai estar disponível para ser reabsorvido e atravessar o epitélio do túbulo renal até o epitélio do fluído intersticial fazendo com que a maior parte do fluoreto na forma de F- seja excretado na urina. O contrário ocorrerá caso a urina estiver relativamente ácida, onde a concentração de HF irá aumentar, aumentando assim o gradiente de concentração transtubular de HF e, consequentemente, o grau de difusão do lúmen tubular para o fluído intersticial, reduzindo a quantidade de íon a ser excretada (Figura 6). Desta forma, qualquer fator que afete o pH urinário terá um impacto sobre a quantidade de fluoreto que é excretado na urina (BUZALAF; WHITFORD, 2011; EKSTRAND, 1996). No fluído intersticial, onde o pH é mantido próximo da neutralidade, independentemente do $\mathrm{pH}$ do fluido tubular, o HF se dissocia e o íon F- se difunde para os capilares, retornando à circulação sistêmica (BUZALAF; CARDOSO, 2008; WITHFORD, 1996).

O clearance renal do fluoreto é bastante alto quando comparado a outros halógenos como o cloro, bromo e iodo. Em jovens e adultos saudáveis o clearance destes elementos está na ordem de $2 \mathrm{~mL} / \mathrm{min}$ ao passo que o do fluoreto é em torno de $35 \mathrm{~mL} / \mathrm{min}$ (EKSTRAND; SPAK; VOGEL, 1990). 

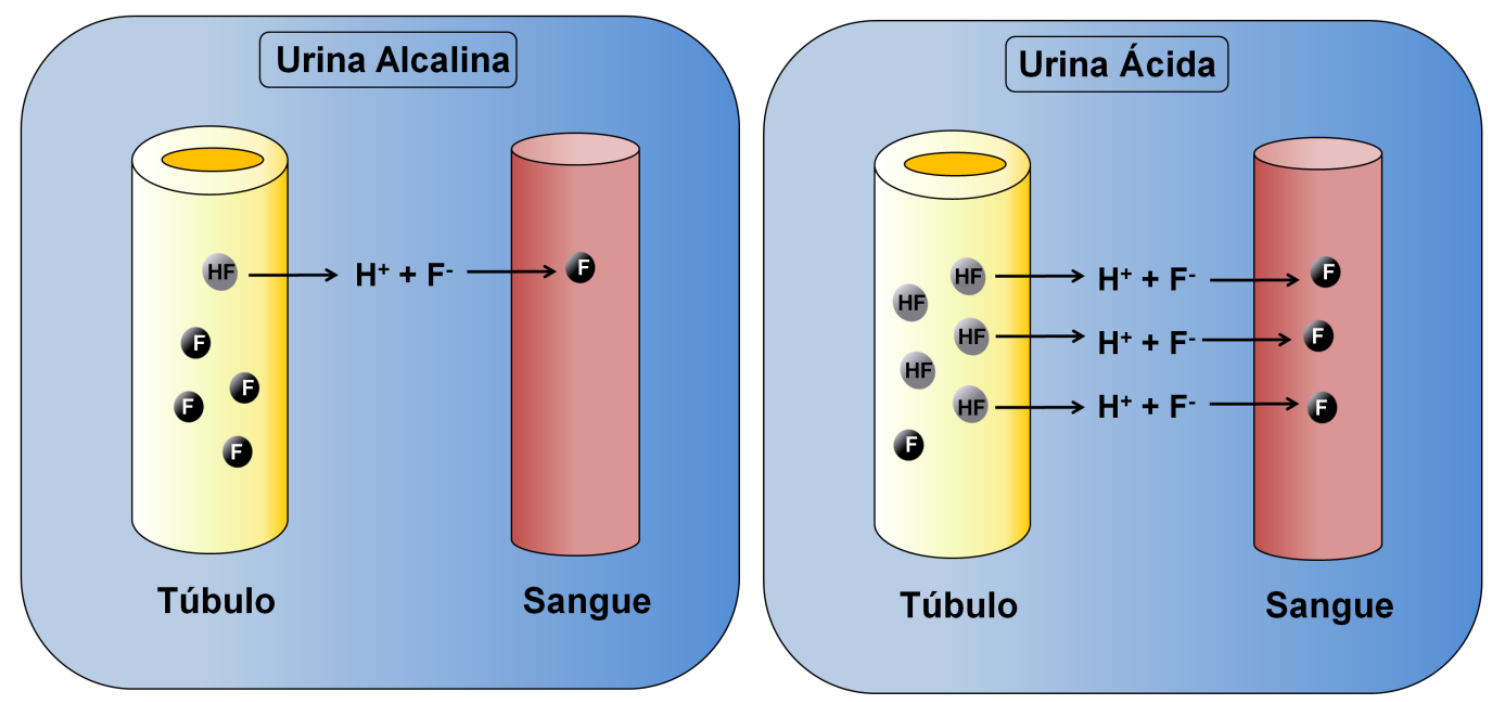

Fonte: Adaptado de: BUZALAF; WHITFORD,2011.

Figura 6 - Mecanismo de reabsorção tubular do fluoreto

A excreção urinária de $\mathrm{F}$ também é influenciada pela taxa de filtração glomerular e a ocorrência de diminuição desta taxa, como na disfunção renal crônica, resulta em menor excreção e aumento dos níveis plasmáticos de $F$ (EKSTRAND, 1996). Em particular, sabe-se que o $\mathrm{F}$ pode causar disfunção renal relacionada com a dose, associada à poliúria, devido à diminuição da capacidade de concentração de urina (CITTANOVA et al., 1996).

A absorção de sódio na parte distal do néfron, e mais especificamente a capacidade do ducto coletor em concentrar a urina, são processos fundamentais no controle da osmolaridade dos fluídos e homeostase do corpo. Neste sentido, qualquer efeito tóxico de $\mathrm{F}$ sobre a função do ducto coletor cortical teria consequências para o organismo como um todo (KOKKO, 1987). As células renais estão expostas as concentrações de $\mathrm{F}$ relativamente altas e mostram um gradiente progressivo de concentração, assim as porções dos rins, responsáveis pela habilidade de concentrar a urina e conservar a água no organismo, como a alça de Henle e ductos coletores, são expostas as concentrações mais elevadas de $\mathrm{F}$ nos rins (WHITFORD, 1996). Foi demonstrado, em modelos de ratos com nefrotoxicidade pela exposição aguda ao $F$, que a parte distal do néfron é mais susceptível a danos que qualquer outra estrutura tubular (CITTANOVA et al., 1996; DOTE et al., 2000). 


\subsection{Toxicidade do Fluoreto}

Apesar dos benefícios do fluoreto, tanto para a saúde como para a escala industrial, este íon pode causar efeitos colaterais se utilizado cronicamente e também em nível de exposição aguda. Seus efeitos variam desde fluorose dentária a distúrbios gástricos reversíveis, reduções transitórias na capacidade de concentração da urina, fluorose esquelética e problemas de ordem neurológica. As respostas diferenciais parecem ser determinadas pela dose e tempo de exposição (EVERETT, 2011; WHITFORD, 1996).

Em 1899, Baldwin ingeriu NaF para analisar os efeitos iniciais da toxicidade do $\mathrm{F}$, na ingestão de $0,03 \mathrm{mg} / \mathrm{kg}$ de $\mathrm{NaF}$ nenhum efeito foi verificado, mas ao aumentar a dose para $0,25 \mathrm{mg} / \mathrm{kg}$ sintomas como náusea, salivação e ânsia de vomito foram relatados (BALDWIN, 1899).

O efeito mais comum ligado a forma crônica é a fluorose dentária que pode ocorrer se a ingestão diária de flúor for superior a $0,1 \mathrm{mg} / \mathrm{kg}$ de peso corporal durante vários meses ou anos (WHITFORD, 1996).

Quando a exposição crônica ocorre no período da formação dos dentes, o fluoreto pode interferir no processo de amelogênese, resultando em um esmalte hipomineralizado. Esta condição é conhecida pelo aparecimento de pequenas linhas brancas ou pode resultar na perda da maior parte do esmalte, dependendo do grau de severidade (FEJERSKOV; RICHARDS; DENBESTEN, 1996).

$\mathrm{O}$ envenenamento agudo pela ingestão de $\mathrm{F}$ em altas concentrações (exposição superior a $5 \mathrm{mg} / \mathrm{kg}$ ) acarreta em rápidos sinais e sintomas, imediatamente ocorrem vômitos com a presença de sangue, náuseas e diarreia, seguida de colapso geral acompanhado por palidez, fraqueza, problemas cardiorrespiratórios, calafrios, cianose e pupilas dilatadas (WITHFORD,1996). Quando esses sinais ocorrem o período de sobrevida é de apenas duas a quatro horas, se prolongada a sobrevida, em vinte horas, ocorrerão efeitos como espasmos e paralisia muscular, acidose metabólica com consequente perda de função respiratória e renal (BUZALAF; WITHFORD, 2011). A intoxicação aguda pode ocorrer por meio da via oral (ingestão), inalação e pelo contato com a pele (WITHFORD, 1996). 
Sabe-se que em muitas áreas do mundo concentrações elevadas de fluoreto (> 1,5 ppm) ocorrem naturalmente nas águas subterrâneas, países como China, Índia, México e Argentina são afetados por áreas endêmicas de fluorose. A exposição crônica ao $\mathrm{F}$, acima de 1,5 ppm, nestas áreas tem sido associado com fluorose dentária e esquelética, infertilidade, diminuição da capacidade intelectual e insuficiência renal (CÁRDENAS-GONZÁLEZ et al., 2013; OMS, 2006). Em 1931, PETREY descobriu acidentalmente que a água utilizada em Bauxite, uma das cidades americanas em que a fluorose dentária (esmalte mosqueado) tornou-se endêmica, possuía 13,7 mg F/L (BURT; FEJERSKOV, 1996).

Em adição, crianças que vivem em áreas endêmicas da China, onde o teor de flúor na água chega a 4,2 mg, apresentaram déficit mental em relação a crianças de áreas não endêmicas (ZHAO et al., 1996).

A toxicidade do $\mathrm{F}$ está associada com a sua atividade biológica e química elevada, seus efeitos sobre o metabolismo celular e a fisiologia variam de acordo com o tipo de célula, concentração e tempo de exposição (AGALAKOVA; GUSEV, 2011, WHITFORD, 1996).

Apesar de vários relatos na literatura sobre a toxicidade de $F$, pouco se sabe sobre os mecanismos celulares e moleculares responsáveis por esse efeito. Já é descrito que o $\mathrm{F}$ em concentrações na ordem de $\mu \mathrm{M}$ induz apoptose de várias linhagens celulares, bem como induz alteração da resposta imunológica (ANURADHA et al., 2001; REFSNES et al., 2001; REFSNES et al., 2003; WANG et al., 2004).

Estudos tem demonstrado que o $\mathrm{F}$ pode interferir em mecanismos moleculares que levam a apoptose, como por exemplo, depleção de ATP, ativação dos receptores de morte da superfície celular, ruptura da membrana externa da mitocôndria, ativação de caspases, expressão de genes relacionados com apoptose, estresse do retículo endoplasmático e perturbações na síntese de proteínas (AGALAKOVA; GUSEV, 2011).

No tecido ósseo, concentrações micromolares de $\mathrm{F}$ apresentam um efeito anabólico promovendo a proliferação celular. Essas concentrações provocam efeitos potencialmente benéficos nas células ósseas ao passo que, nas células de outros tecidos tem mostrado influenciar negativamente condições metabólicas, estruturais e funcionais, como a supressão da proliferação celular e a inibição de algumas 
enzimas como a pirofosfatase (inibida com 50-200 $\mu \mathrm{L}$ ) que é muito sensível ao $\mathrm{F}$. (BARBIER et al., 2010; JACINTO- ALEMAN et al., 2010; JANCKILA et al., 1992; SHANTHAKUMARI et al., 2004).

Diversos trabalhos experimentais empregando doses crônicas elevadas de fluoreto têm relatado problemas em outros tipos de tecidos, afetando diversos sistemas proteicos e enzimáticos, mas o maior alvo dentre os tecidos moles são os rins (BUZALAF; WHITFORD, 2011).

Sendo o rim a maior rota de remoção de $\mathrm{F}$ do organismo, a concentração de $\mathrm{F}$ no lúmen dos túbulos renais é desconhecida, mas a concentração no rim como um todo é significativamente maior (4-5 vezes) do que no plasma., Desta maneira, sugere-se que a toxicidade do $F$ é superior no rim do que em outros tecidos (WHITFORD; BUZALAF, 2011; WHITFORD, 1996). De acordo com esta sugestão, estudos indicaram efeitos tóxicos de $\mathrm{F}$ nos rins, mais especificamente associadas ao uso de anestésicos gerais fluoretados em altas doses agudas, tanto em células do ducto de coletor cortical in vitro quanto sobre a função renal in vivo (CITTANOVA et al., 1996; MAZZE et al., 1977).

Em 1960 foi observada grande falha renal em alguns pacientes que fizeram o uso de metoxiflurano, um anestésico fluoretado volátil, sendo que os níveis plasmáticos de fluoreto no dia seguinte à anestesia chegavam em torno dos $0,4 \mathrm{a}$ $1,2 \mu \mathrm{g} / \mathrm{mL}$, podendo chegar a $6 \mu \mathrm{g} / \mathrm{mL}$ em casos extremos (FRY; TAVES; MERIN, 1973).

Xiong et al. (2007), verificou a relação dose/efeito entre níveis de flúor na água e os danos as funções renais, e demonstrou que não houve diferença nos níveis de proteína ou albumina em crianças expostas de 0,61 a 5,69 ppm de flúor Porém, no mesmo estudo, análises com células epiteliais tubulares revelaram que a exposição em níveis superiores a 2 ppm de flúor seria capaz de prejudicar a função renal em crianças, chegando-se a conclusão de que níveis de $\mathrm{F}$ acima de $2.0 \mathrm{mg} / \mathrm{L}$ na água de beber poderiam causar danos nas funções renais.

Alguns estudos in vitro com células do túbulo proximal renal de humanos evidenciaram que a exposição ao $F$ causou citotoxicidade dose-dependente, e mesmo o tratamento com doses baixas de $\mathrm{F}$ provocou disfunção tubular, levando a redução na reabsorção de proteínas e aumento da excreção urinária de cálcio e fosfato (SANTOYO-SANCHEZ et al., 2013; ZAGER et al., 1997). 
Um estudo com células imortalizadas humanas de ducto coletor expostas ao $F$ mostrou que nas concentrações de 1 e $5 \mathrm{mM}$ as células apresentaram alterações mitocondriais, e o comprometimento desta organela levou a diminuição dos níveis de ATP, que implicou no comprometimento do transporte ativo no ducto coletor (CITTANOVA et al., 1996).

Outros estudos demonstraram que a administração de $\mathrm{NaF}$ (50 mg/L) na água de beber, durante 6 meses, produziu estresse oxidativo e apoptose renal em ratos. Os achados indicaram que a fluorose crônica pode levar a uma dinâmica mitocondrial anormal, além de mudanças na morfologia renal, estes mecanismos foram induzidos pelo alto nível de estresse oxidativo (QIN et al., 2015; YU et al., 2006).

Efeitos como aumento da apoptose de células renais, alteração na estrutura renal, degeneração vascular, glomerular e tubular, causados pela exposição crônica a doses relativamente baixas de $\mathrm{F}$, foram relatados em roedores em estudo in vivo, e a citotoxicidade foi evidenciada por meio de biomarcadores de dano renal na urina e análise histológica dos túbulos renais (CHATTOPADHYAY et al., 2011; CÁRDENAS-GONZÁLEZ et al., 2013).

Mudanças estruturais marcantes têm sido relatadas em rins de animais com intoxicação crônica ou aguda por $F$, tais como hemorragia, hiperemia glomerular e medular, alterações inflamatórias, destruição tubular e edema intersticial (KOBAYASHI, 2009).

O tratamento de células com $\mathrm{NaF}$ em doses altas causa inibição da proliferação celular, afetando os níveis de expressão de fatores de resposta ao estresse, de proteínas relacionadas à apoptose e de componentes de transdução de sinal (SONG et al., 2014)

Acredita-se que pelo menos três classes de proteínas envolvidas em pontos chave na transdução de sinal sejam afetadas pelo $\mathrm{F}$ : proteínas $\mathrm{G}$, proteínas quinases e proteínas fosfatases (REFSNES et al., 2003).

Análises proteômicas tem revelado que a exposição a baixos níveis de $F$ provoca alterações nos níveis de expressão de uma variedade de proteínas em camundongos da linhagem 129P3/J e A/J. A maioria das quais se enquadram na categoria de proteínas "house-keeping", como por exemplo, o aumento da expressão da proteína serina/treonina fosfatase (PP1), que regula a função de 
muitas proteínas, incluindo canais e transportadores, tais como o cotransportador $\mathrm{Na}^{+}-\mathrm{K}^{+}-2 \mathrm{Cl}$ (NKCC1), os canais Cystic Fibrosis Transmembrane Conductance Regulator (CFTR) e o canal de $\mathrm{Na}^{+}$epitelial (ENaC) (CARVALHO et al., 2013; BECCHETTI et al., 2002; DARMAN et al., 2001; MORI et al., 2001). Além de alterar a expressão do cofator de regulação do trocador $\mathrm{Na}^{+} / \mathrm{H}^{+}$, NHE-RF3 (PDZK1), que foi significativamente reduzida nos rins dos ratos da linhagem 129P3/J, estes efeitos a estas proteínas chave poderiam influenciar a reabsorção de íons através da inibição ou aumento da atividade dos canais transportadores (CARVALHO et al., 2013).

Os efeitos diretos do $\mathrm{F}$ em proteínas de transporte, incluindo a bomba $\mathrm{Na}^{+} / \mathrm{K}^{+}$-ATPase, o canal CFTR e os transportadores de cálcio, já foram descritos (BARBIER et al., 2010). 
2Revisão de Literatura 
3 Proposição 



\section{PROPOSIÇÃO}

Considerando o rim como a maior rota de passagem do $F$, e principal órgão responsável pela sua eliminação, buscamos, com este projeto, avaliar o efeito que este íon exerce sobre a viabilidade de células epiteliais do ducto coletor de rim, mediante a utilização de concentrações semelhantes às que podem ser encontradas no néfron durante a fluorose dentária. Procurando estabelecer um melhor entendimento sobre sua atuação nos canais de transporte iônico em consequência sob as células renais expostas ao F. Portanto, este trabalho objetivou especificamente:

1. Investigar os efeitos de diferentes concentrações de $\mathrm{F}$ (na forma de $\mathrm{NaF}$ ) sobre a viabilidade das células epiteliais tubulares renais, explorando também a resposta celular frente a diferentes períodos de exposição ao $\mathrm{F}$.

2. Analisar comparativamente a viabilidade de células tratadas com $\mathrm{NaF}$ e células tratadas com outro tipo de sal $(\mathrm{NaCl})$ a fim de estabelecer a relação entre o efeito que o $\mathrm{Na}^{+}$, presente nestes compostos iônicos, pode exercer sobre as células.

3. Analisar qualitativamente a distribuição de duas proteínas presentes na formação do canal de sódio epitelial $(\mathrm{ENaC})$, e mensurar sua quantidade nas células renais expostas ao $\mathrm{F}$.

4. Estabelecer uma relação entre a exposição das células ao $\mathrm{F}$ e a expressão de genes envolvidos na expressão das proteínas do canal de sódio epitelial $(\mathrm{ENaC})$. 
3 Proposição 
4 Material e Métodos 



\section{MATERIAL E MÉTODOS}

A linhagem M-1 ATCC (American Type Culture Collection) CRL-2038 ${ }^{\mathrm{TM}}$, provinda de células epiteliais do ducto coletor cortical, foram adquiridas por meio da parceria com o professor John Michael Edwardson, responsável pelo departamento de farmacologia da Universidade de Cambridge - Reino Unido. Esta linhagem foi estabelecida a partir de tecido renal normal de camundongos Mus musculus transgênico para o início da região do vírus Simian 40, o que torna esta linhagem imortalizada.

\subsection{Cultura Celular}

Inicialmente células da linhagem M-1 (ATCC CRL-2038 ${ }^{\mathrm{TM}}$ ) (Figura 7) foram cultivadas em garrafas plásticas de $25 \mathrm{~cm}^{2}$ (Corning ${ }^{\circledR}$ ) contendo meio de cultura DMEM F-12 (GIBCO®) suplementado com 10\% de Soro Fetal Bovino (GIBCO $\AA$ ) e 0,005 mM de Dexametasona (Sigma-Aldrich), sendo mantidas em estufa sob atmosfera de $5 \% \mathrm{CO}_{2} /$ ar e temperatura de $37^{\circ} \mathrm{C}$ de incubação, a troca do meio de cultura foi realizada a cada dois dias.

O meio de cultura DMEM F-12 contendo L-glutamina 2,5 mM, HEPES 15 $\mathrm{mM}$, piruvato de sódio $0,5 \mathrm{mM}$ foi preparado com a adição de $1,2 \mathrm{~g}$ de bicarbonato de sódio e teve $\mathrm{opH}$ ajustado para 6,8. Em seguida foi filtrado para sua esterilização. Uma solução estoque de $10 \mathrm{mM}$ de Dexametasona $(25 \mathrm{mg}$ de dexametasona em $6 \mathrm{~mL}$ álcool etílico absoluto) foi preparada e aliquotada. Por fim, o meio já filtrado foi acrescido com $1 \%$ de antibiótico Penicilina-Estreptomicina (SigmaAldrich) e $125 \mu \mathrm{L}$ de Dexametasona da solução estoque de $10 \mathrm{mM}$ para um volume final de meio de $250 \mathrm{~mL}$.

Ao atingirem confluência de 70 a $80 \%$ na garrafa, as células do cultivo inicial, foram tripsinizadas com $2 \mathrm{~mL}$ de Tripsina-EDTA (0,25\%) (GIBCO®) por 10 minutos a $37{ }^{\circ} \mathrm{C}$, em seguida a inativação da tripsina foi feita com meio contendo SBF. Logo após, foram levadas para centrifugação a 1200 RPM por 5 minutos, onde o pellet celular foi ressuspendido em meio de cultura DMEM F-12 10\% SFB para que as células fossem contadas em câmara de Neubauer utilizando o Azul de Trypan, que exclui a contagem de células inviáveis, e assim fosse feito o cultivo em garrafa 
T75 na densidade de $4 \times 10^{5}$ células $/ \mathrm{cm}^{2}$. A partir disso as células foram expandidas para a confecção do banco de células e realização dos experimentos.

Para a confecção do banco de células, as mesmas foram congeladas em meio contendo 30\% SFB e 5\% DMSO (Sigma-Aldrich) em uma proporção de $1 \times 10^{6}$ células em cada vial, os vials eram a princípio congelados a $-80^{\circ} \mathrm{C}$ por 24 horas e após esse tempo, armazenadas em nitrogênio líquido. Para os experimentos, os vials, devidamente identificados quanto a data de congelamento e passagem, foram descongelados e as células cultivadas (passagens entre 15 e 22) seguindo os mesmos procedimentos do cultivo inicial e as trocas de meio também foram realizadas a cada dois dias.

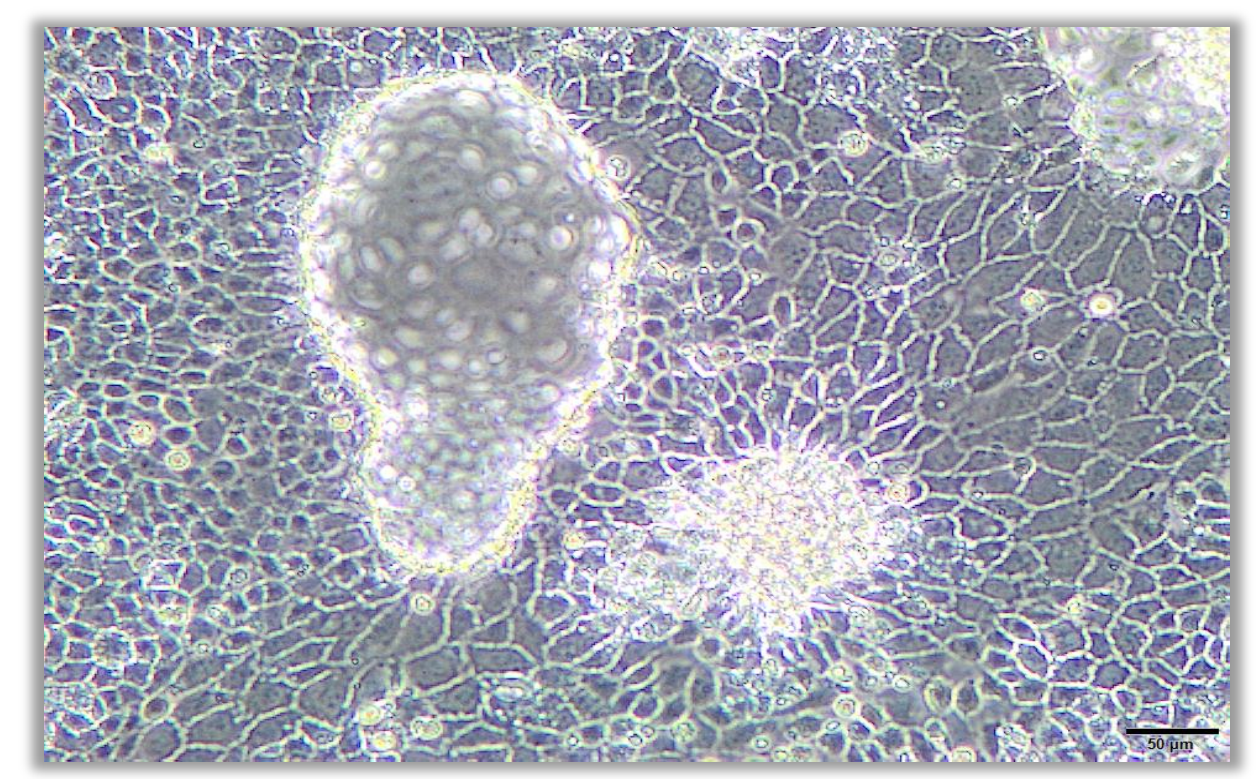

Figura 7 - Fotomicrografia feita em aumento de 20x no microscópio de fase invertida (LEICA/ DM IRBE), de campo claro, das células da linhagem M-1 (ATCC CRL-2038 ${ }^{\mathrm{TM}}$ ).

\subsection{Tratamento com $\mathrm{NaF}$ e $\mathrm{NaCl}$ e ensaios de viabilidade}

A viabilidade celular foi determinada a partir do tratamento das células $M$ 1 com diferentes concentrações de $F$, que são semelhantes às que podem ser encontradas no néfron durante a fluorose dentária. A fonte oriunda de $\mathrm{F}$ escolhida foi o $\mathrm{NaF}$, por se tratar do sal mais amplamente utilizado, é incorporado a dentifrícios, bebidas e também usado na fluoretação da água (AOBA \& FEJERSKOV; 2002).

Este trabalho, inicialmente, não somente buscou avaliar a resposta das células renais frente ao tratamento com $\mathrm{NaF}$ como também verificou uma possível 
influência de $\mathrm{Na}^{+}$sobre as células, visto que este íon faz uma ligação iônica com halogênios como o cloro e o flúor. Desta forma, determinamos a adição de mais um grupo experimental de tratamento com o sal $\mathrm{NaCl}$, utilizando as mesmas concentrações usadas para $\mathrm{NaF}$.

Para determinar os efeitos do $\mathrm{F}$ sobre a cultura celular, as células $\mathrm{M}-1$ foram tratadas com as seguintes concentrações de NaF: $10 \mu \mathrm{M}, 40 \mu \mathrm{M}, 100 \mu \mathrm{M}$, $200 \mu \mathrm{M}$ e $400 \mu \mathrm{M}$. As mesmas concentrações foram utilizadas para $\mathrm{NaCl}$.

$\mathrm{O}$ preparo dos tratamentos foi feito a partir da pesagem dos sais de $\mathrm{NaF}$ (Merck Millipore) e $\mathrm{NaCl}$ (Sigma Aldrich) que em seguida foram diluídos em PBS 1X, o cálculo da molaridade da solução foi feito para que obtivéssemos uma solução estoque de $40 \mathrm{mM}$ de $\mathrm{NaF}$ e $\mathrm{NaCl}$. Cada solução foi filtrada dentro do fluxo laminar com filtros estéreis de seringa (Millex®) e a partir daí foi feita a diluição dos grupos experimentais. As diluições das concentrações de tratamento foram feitas em meio DMEM F-12 suplementado com 10\% SFB.

A viabilidade celular foi avaliada após 24, 48, 72 e 96 horas de exposição das células aos sais $\mathrm{NaF}$ e $\mathrm{NaCl}$, por meio dos ensaios de redução do MTT e Cristal Violeta, descritos nos itens a seguir.

O plaqueamento das células foi feito em placas de 48 poços (corning) na densidade de $1 \times 10^{4}$ células por poço, e após serem plaqueadas as células permaneciam em cultivo por sete dias, antes de serem utilizadas nos ensaios de viabilidade, e a cada três dias, durante este período, o meio era trocado.

O longo período de cultivo foi necessário para que as células $\mathrm{M}-1$ adquirissem características específicas desta linhagem, esta diferenciação particular ocorre somente após a progressão celular. A diferenciação celular pode ser vista por meio de marcadores específicos da linhagem que diferem dos marcadores expressos pelas células-tronco e estabelecem a relação de uma determinada linhagem celular com seu tecido de origem. Como por exemplo, o rim realiza o transporte de íons inorgânicos e a transferência resultante de água, sendo assim, o epitélio renal será caracterizado como absorvente e secretor e crescerá em monocamada (FRESHNEY, 2010).

As células epiteliais $M-1$ crescem em monocamada e após certo tempo produzem cúpulas ou "domes" celulares, estas cúpulas são causadas pelo acumulo de água na parte inferior da monocamada. Desta forma os experimentos só eram 
realizados após a visualização da formação de "domes" celulares (Figura 8) na cultura.

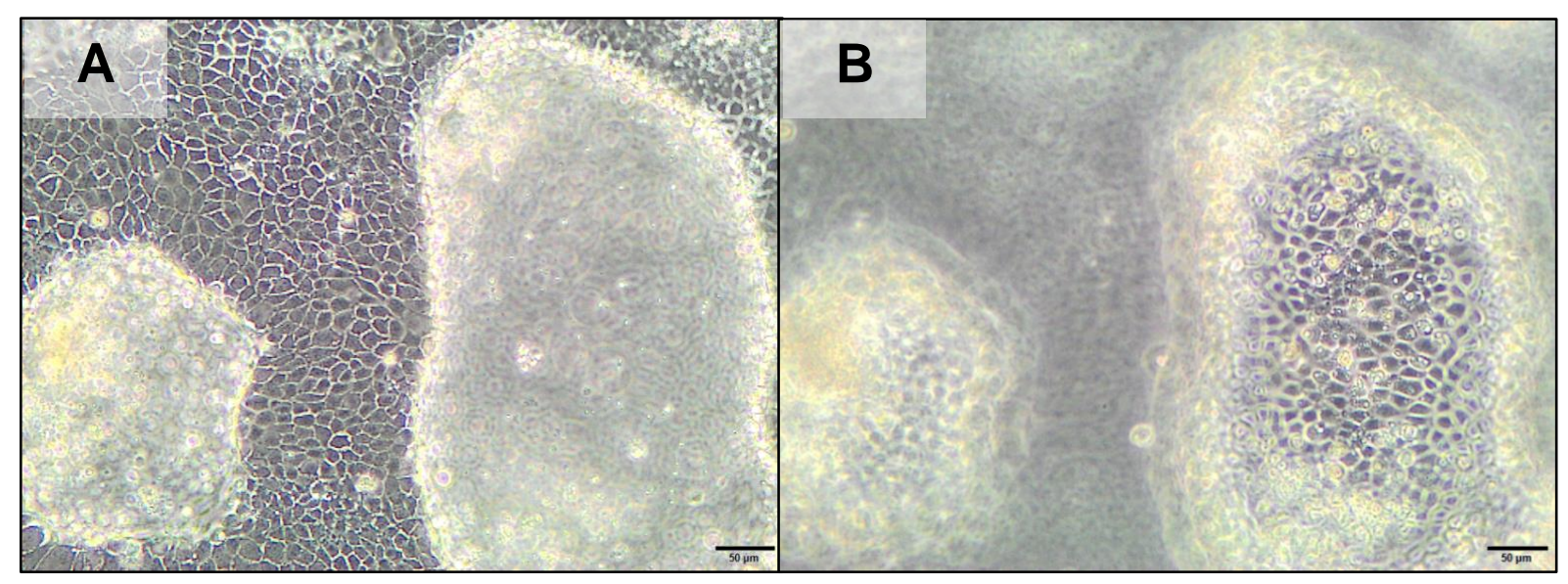

Figura 8 - (A) fotomicrografia dos "domes" celulares formados em uma monocamada epitelial devido ao transporte para baixo de íons e água. (B) Foco superior no topo dos "domes". Microscópio de fase invertida LEICA/ DM IRBE, objetiva 20X.

Os ensaios foram feitos com número amostral de 6 replicatas para cada concentração de $\mathrm{NaF}$ e NaCl, assim como o grupo controle (células sem tratamento) e o grupo sem células contendo apenas meio de cultura (branco), representado na Figura 9. 

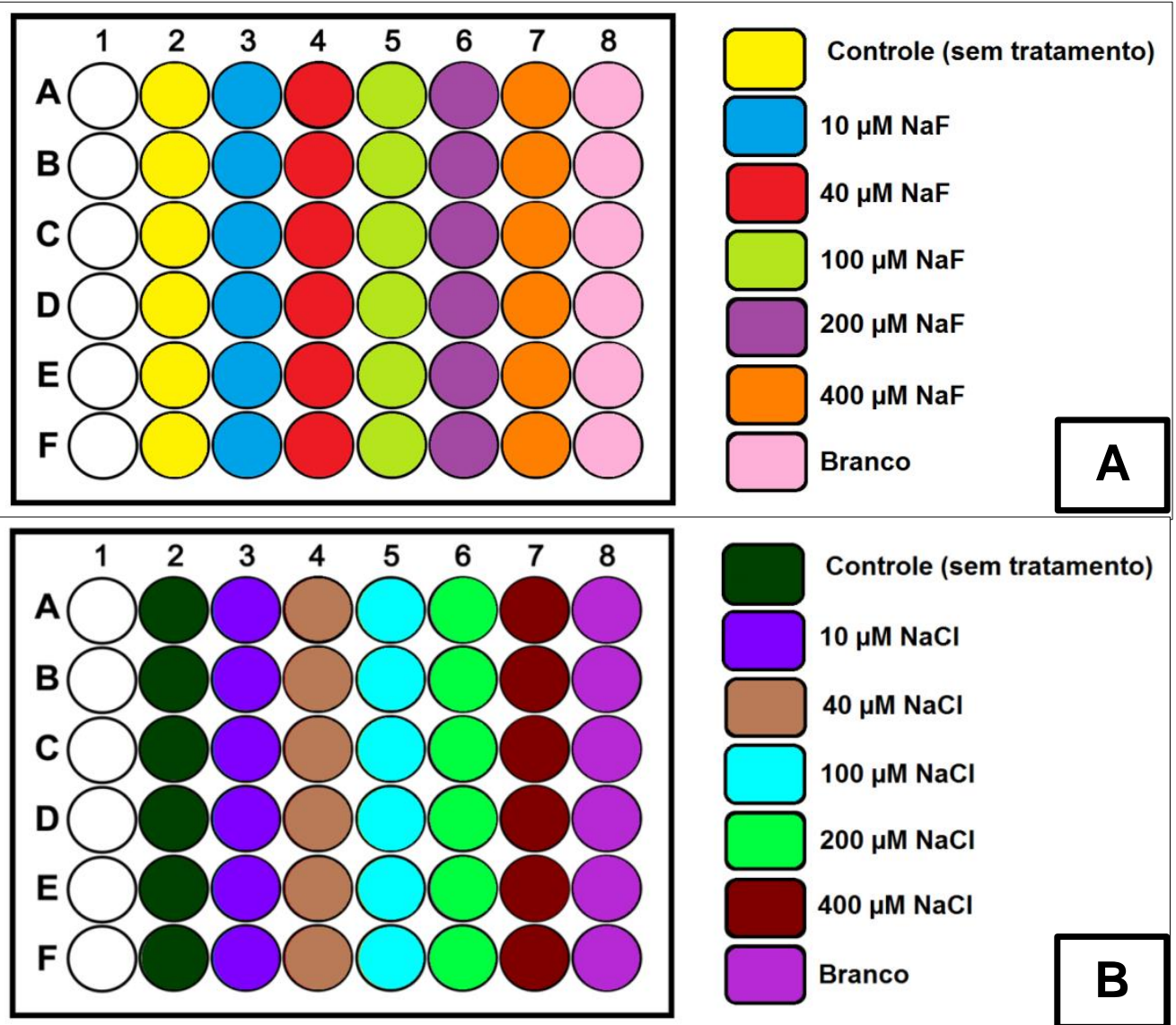

Controle (sem tratamento) $10 \mu \mathrm{M} \mathrm{NaCl}$

$40 \mu \mathrm{M} \mathrm{NaCl}$

$100 \mu \mathrm{M} \mathrm{NaCl}$

$200 \mu \mathrm{M} \mathrm{NaCl}$

$400 \mu \mathrm{M} \mathrm{NaCl}$

Branco

Figura 9 - Layout da placa de 48 poços utilizada nos ensaios de viabilidade celular. (A) Disposição do grupo controle, grupos de tratamento com NaF e branco na placa. (B) Disposição do grupo controle, grupos de tratamento com $\mathrm{NaCl}$ e branco na placa.

\subsubsection{Redução do MTT}

O ensaio da redução do MTT (brometo de 3-(4,5-dimetiltiazol-2-yl)-2,5difeniltetrazólio) (Figura 10) se baseia na capacidade das células viáveis, por meio da atividade mitocondrial, reduzirem metabolicamente o sal de MTT (MOSMANN, 1983). O MTT, solúvel em água, é convertido por meio da enzima mitocondrial desidrogenase succínica em cristais de formazan, o qual é insolúvel, e se acumula no citoplasma celular. Neste ensaio o formazan, de cor azul purpúrea, é solubilizado e então sua concentração é determinada pela densidade óptica no espectrofotômetro (Epoch - Biotek).

Após 24, 48, 72 e 96 horas de exposição aos tratamentos, o sobrenadante foi removido e então as células foram lavadas com $300 \mu \mathrm{L}$ PBS $1 \mathrm{X}$. Em seguida foi adicionado $290 \mu \mathrm{L}$ da solução contendo meio DMEM F-12 e 0,5 mg 
de $\mathrm{MTT} / \mathrm{mL}$ nos poços. As células foram incubadas em estufa de $\mathrm{CO}_{2}$ a $37^{\circ} \mathrm{C}$ durante 4 horas e protegidas da luz. Passado o período de incubação, a solução de MTT foi retirada e o pigmento insolúvel reduzido intracelularmente foi ressuspendido em $290 \mu \mathrm{L}$ de dimetilsulfóxido (DMSO). A leitura das placas foi realizada no leitor de microplacas com filtro de $550 \mathrm{~nm}$.

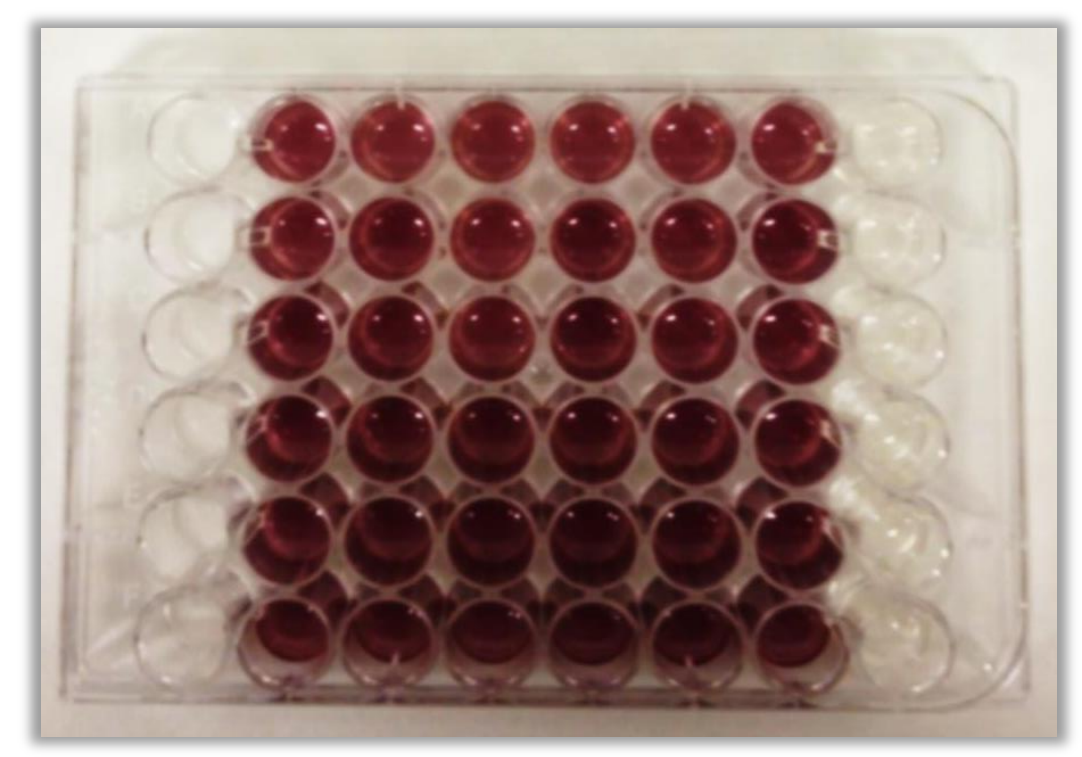

Figura 10 - Imagem ilustrativa da placa do ensaio Redução do MTT após incubação e posterior dissolução dos cristais de formazan com DMSO.

\subsubsection{Cristal Violeta}

O teste de cristal violeta (Figura 11) é utilizado para determinar a viabilidade por corar o DNA celular, desta forma avalia a densidade de células, sendo que, após a lavagem do excesso do corante a absorbância equivale à quantidade de células no poço (KUENG et al., 1989).

Após 24, 48, 72 e 96 horas de tratamento das células, o sobrenadante foi removido e as células foram lavadas com $300 \mu \mathrm{L}$ PBS $1 \mathrm{X}$. Em seguida foi adicionado $200 \mu \mathrm{L}$ de metanol $100 \%$ (J.T.Baker) por 10 minutos. Após esse tempo, o metanol foi removido e adicionou-se $200 \mu \mathrm{L}$ da solução de cristal violeta $0,2 \%$ em etanol $2 \%$ por 3 minutos. Em seguida o corante foi removido e a placa foi submergida em água deionizada, para a retirada o excesso de corante. Por fim, acrescentou-se $200 \mu \mathrm{L}$ da solução de citrato de sódio $0,05 \mathrm{~mol}^{-\mathrm{L}^{-1}} \mathrm{com}$ etanol $50 \%$ 
durante 10 minutos. A leitura das placas foi realizada no leitor de microplacas (Epoch - Biotek) com filtro de 540nm.

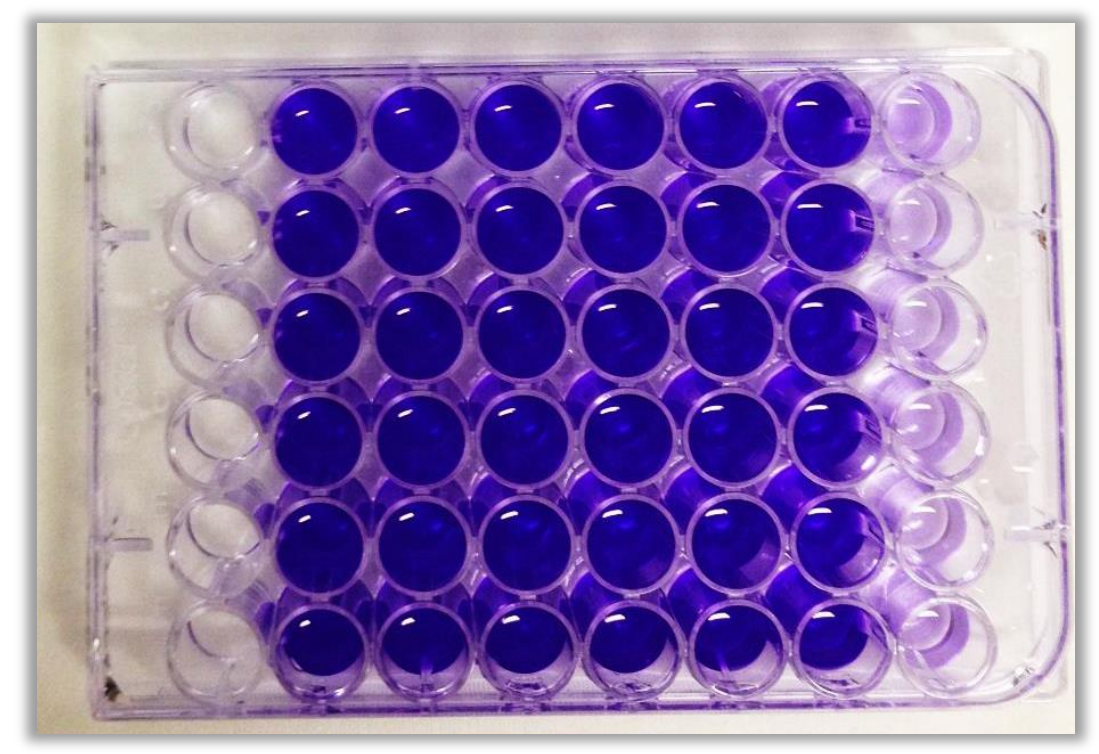

Figura 11 - Imagem ilustrativa da placa do ensaio de viabilidade cristal violeta após adição de citrato de sódio a 0,05 mol. $\mathrm{L}^{-1}$.

\subsection{Imunofluorescência}

Após terem sido feitos os ensaios de viabilidade delimitamos as concentrações e os períodos de tratamento de maior importância para este trabalho, desta forma, para o ensaio de imunofluorescência foram usadas as concentrações, tanto para $\mathrm{NaF}$ quanto para $\mathrm{NaCl}$, de $100 \mu \mathrm{M}, 200 \mu \mathrm{M}$ e $400 \mu \mathrm{M}$ nos períodos experimentais de exposição de 24 e 48 horas. Os alvos escolhidos para esta técnica foram as subunidades alfa e gama que fazem parte da constituição do canal de sódio epitelial, levando em consideração que em camundongos o gene Scnn1a, que codifica subunidade alfa, está localizado no cromossomo 6, e Scnn1b e Scnn1g são justapostos em uma região do cromossomo 7 (BROOKER et al., 1995; PATHAK et al., 1996). Desta maneira priorizou-se analisar os efeitos induzidos por $\mathrm{F}$ em regiões genômicas diferentes.

O princípio da imunofluorescência consiste na detecção de antígenos (proteínas) específicos presentes nas células por meio da marcação destes com seus respectivos anticorpos conjugados com fluorocromos, que emitem fluorescência ao serem irradiados por uma determinada luz (ODELL; COOK, 2013). 
Com esta técnica pudemos verificar a distribuição de duas subunidades do canal de sódio epitelial $(\mathrm{ENaC})$ e analisar qualitativamente aspectos morfológicos celulares frente ao $\mathrm{F}$, bem como, a resposta desses canais comparando-os com o grupo sem tratamento.

Foi adotado um grupo controle (sem tratamento com $\mathrm{NaF}$ ou $\mathrm{NaCl}$ ) para cada alvo (gama ou alfa), visto que, os alvos foram marcados separadamente em cada grupo experimental.Também foi adotado um controle negativo sem tratamento e sem marcação dos alvos com os anticorpos policlonais primários lgG de coelho anti-yENaC (Santa Cruz®) e anti-aENAC (Santa Cruz®), para verificar se haveria ocorrência de reação cruzada entre o anticorpo monoclonal secundário (IgG de rato anti-coelho conjugado com PE) (Santa Cruz®) e antígenos inespecíficos da célula.

As células M-1 foram cultivadas em placas de 24 poços sobre as lamínulas estéreis de plástico (TC Coverslip Sarstedt) de $13 \mathrm{~mm}$ de diâmetro. As lamínulas usadas foram obrigatoriamente de plástico, pois, o $\mathrm{F}$ tem alta reatividade com o vidro. A densidade celular utilizada foi de $1 \times 10^{5}$ e as células permaneceram por sete dias em cultura antes de receber os tratamentos.

Passados os períodos de tratamento os sobrenadantes foram descartados e todos os poços lavados com $500 \mu \mathrm{L}$ de PBS $1 \mathrm{X}$, em seguida, todo o PBS foi removido e as células foram fixadas com $500 \mu \mathrm{L}$ metanol (MERCK) durante 15 minutos. O metanol foi então retirado e as células lavadas com PBS 1X por três vezes, durante 5 minutos, para que o excesso de metanol fosse retirado.

As lamínulas foram bloqueadas com $500 \mu \mathrm{L}$ de solução de bloqueio (3\% de BSA, 0,8\% Triton X-100, PBS 0,1M) durante 1 hora a temperatura ambiente.

Para a marcação dos alvos, as lamínulas foram novamente lavadas três vezes a cada 5 minutos com PBS $1 \mathrm{X}$, e foi feita a adição de $200 \mu \mathrm{L}$ de cada anticorpo primário, diluídos em PBS + BSA 1\% numa proporção de 1:100, nos grupos experimentais (exceto controle negativo). A incubação foi feita a $4^{\circ} \mathrm{C}$ overnight.

Após a incubação com os anticorpos primários mais três lavagens com PBS 1X (5 min. cada lavagem) foram realizadas e o anticorpo secundário conjugado com fitocoeritrina (PE), diluído em BSA 1\% na proporção de 1:100, foi incubado durante 3 horas no escuro à temperatura ambiente. Decorrido este tempo, seguiramse mais três lavagens de 5 minutos e $500 \mu \mathrm{L}$ de DAPI (Thermo Fischer) $300 \mu \mathrm{M}$ 
diluído em PBS numa proporção de 1:500, foi adicionado durante 20 minutos para a marcação do núcleo das células.

As lamínulas foram então retiradas da solução de DAPI com o auxílio de uma pinça e colocadas sobre aproximadamente $10 \mu \mathrm{L}$ de meio de montagem (Vectashield®) previamente pipetado nas lâminas de vidro, devidamente identificadas. Até a secagem do meio de montagem todas as lamínulas permaneceram no escuro e quando secas foram seladas com esmalte.

\subsection{Aquisição das imagens e quantificação da fluorescência}

Depois de prontas as lâminas de imunofluorescência foram analisadas no microscópio confocal a laser (Leica TCS SP5) (Figura 12) e as imagens foram adquiridas seguindo os mesmos padrões para todos os grupos, como intensidade do laser e dimensões de imagem (1024X1024). Em cada grupo foi feita a aquisição de imagens em cinco campos distintos (quatro imagens na objetiva de 40X e uma imagem na objetiva de 60X) e todos os campos foram escolhidos aleatoriamente.

A intensidade da fluorescência foi medida pelo software AxioVision 4.8.2 (Zeiss), para esta análise foram utilizadas apenas as imagens dos quatro campos no aumento de 40X, ao passo que, a imagem adquirida no aumento de $60 \mathrm{X}$ foi utilizada para fins qualitativos.

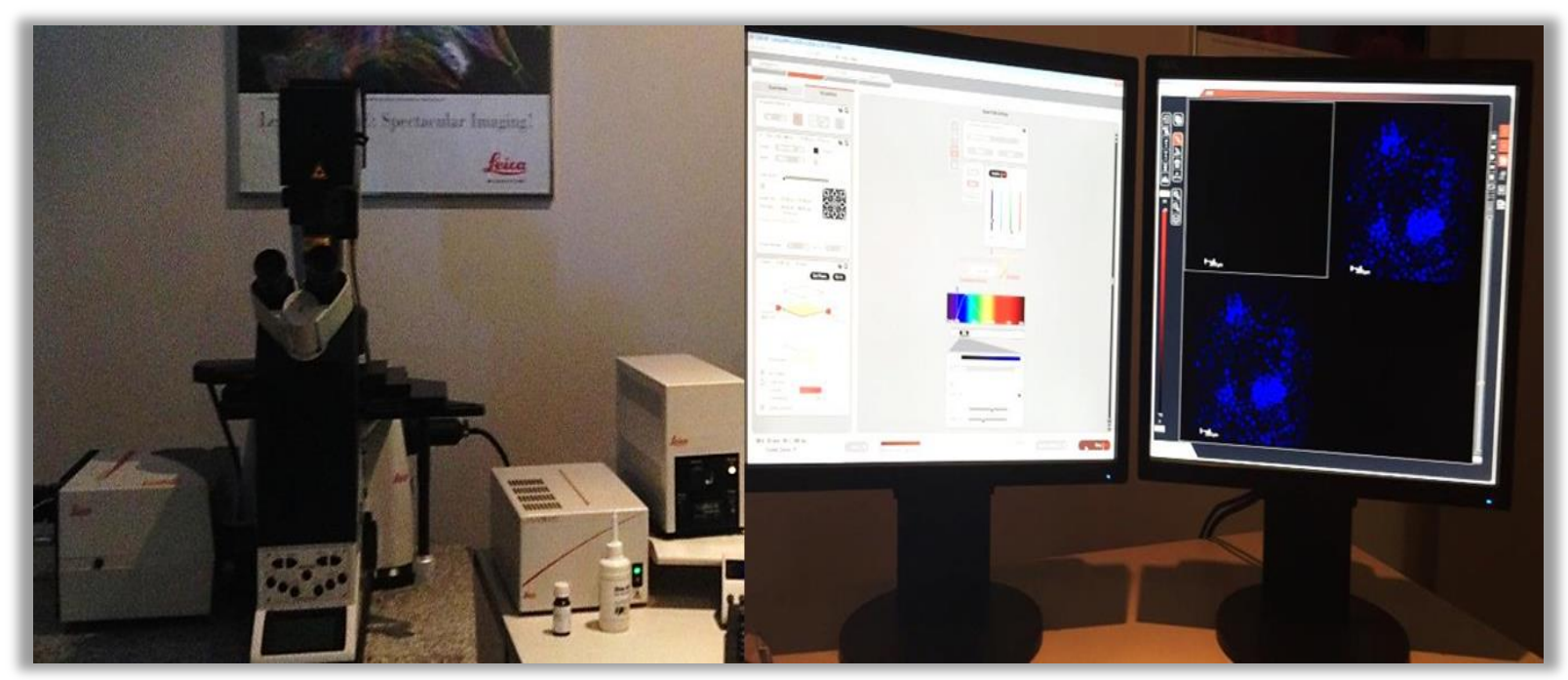

Figura 12 - Imagem ilustrativa do microscópio confocal a laser (Leica TCS SP5). 


\subsection{Coleta das amostras para RT-PCR}

Para a realização do ensaio RT-PCR as células $\mathrm{M}-1$ foram cultivadas em placas de seis poços na densidade de $5 \times 10^{5}$, somente as concentrações de $100 \mu \mathrm{M}$, $200 \mu \mathrm{M}$ e $400 \mu \mathrm{M}$ de NaF serão testadas neste experimento, nos períodos de 24 e 48 horas. Todos os grupos experimentais, incluindo o controle (sem tratamento), foram plaqueados em triplicata. Após o período de cultivo (7 dias) e o período de tempo de tratamento, as células, foram coletadas utilizando o protocolo de coleta com o buffer $\beta$-mercapto, desta forma, o protocolo de extração de RNA foi baseado no tipo de coleta com este tampão.

Antes de iniciar a coleta todos os materiais manuseados foram limpos com DNAse Zap (Thermo Fischer), bem como as luvas utilizadas para manipulação, além de ser feito o preparo da solução buffer RTL/ $\beta$-mercapto para a lise e coleta das células.

O preparo da solução foi feito a partir de $1 \mathrm{~mL}$ de buffer RTL (Quiagen) para cada $10 \mu \mathrm{L}$ de $\beta$-mercaptoethanol (Sigma-Aldrich), e a quantidade de buffer foi preparado em razão do número de poços vezes o volume total de buffer colocado em cada poço, ou seja, $350 \mu \mathrm{L}$.

O sobrenadante foi retirado dos poços e $1 \mathrm{~mL}$ de PBS $1 \mathrm{X}$ foi adicionado para a lavagem dos poços. O PBS foi totalmente retirado e a placa foi colocada em uma superfície de gelo, para evitar degradação das amostras, e $350 \mu \mathrm{L}$ de solução buffer RTL/ $\beta$-Mercapto foi adicionado em cada poço.

Com o cell scraper (Sigma-Aldrich) foi feita a raspagem dos poços para retirada total das células aderidas, logo após a raspagem o conteúdo dos poços foi coletado em microtubos, devidamente identificados, e armazenado no freezer - 80 até o momento da continuação do protocolo de extração de RNA.

A extração de RNA foi realizada pelo método de extração por colunas utilizando-se o RNeasy Mini Kit-79254 (Qiagen), de acordo com as instruções do fabricante. Após a extração, um total de $30 \mu \mathrm{L}$ de RNA suspenso em água DEPC foi obtido em cada amostra, e foi feita a quantificação do RNA extraído no aparelho NanoDrop (Thermo Fischer). 


\subsection{RT-PCR}

Os genes alvos analisados nesta técnica foram os genes Scnn1a sodium channel, nonvoltage-gated 1 alpha, Scnn1b sodium channel, nonvoltage-gated 1 beta e Scnn1g sodium channel, nonvoltage-gated 1 gamma, responsáveis pela expressão do Canal de Sódio Epitelial (ENaC).

A escolha destes alvos levou em consideração que, a maioria dos genomas de vertebrados tem um gene que codifica a subunidade delta, no entanto, - genoma de camundongo parece ter perdido o gene da subunidade delta (GIRALDEZ et al., 2012).

Após a quantificação, um total de $2 \mu \mathrm{g}$ de RNA, de cada amostra, foi reversamente transcrito utilizando o RevertAid RT reverse Transcription Kit (Thermo Fischer), de acordo com as recomendações do fabricante.

O equivalente a $0,1 \mu \mathrm{g}$ de cDNA, sintetizado a partir do RNA mensageiro, foram utilizados para as reações e ${ }_{\mathrm{q}} R T$ T-PCR quantitativo foi realizado utilizando-se $o$ Sensi mix Hi-Rox SYBR Green (Bioline).

A reação básica de amplificação compreende 2 minutos a $50^{\circ} \mathrm{C}, 10$ minutos a $95^{\circ} \mathrm{C}$, e quarenta ciclos de 15 segundos a $95^{\circ} \mathrm{C}$ e 1 minuto a $60^{\circ} \mathrm{C}$. Além de um ciclo final de 20 minutos, com temperatura crescente de 60 a $95^{\circ} \mathrm{C}$, empregada para a obtenção de uma curva de dissociação dos produtos da reação, utilizada para a análise da especificidade de amplificação.

Todas as amostras foram submetidas a reações para a detecção de RNA mensageiro para RPL13, um gene constitutivo, utilizado como controle da integridade das amostras e como controle positivo da reação de amplificação. Uma amostra negativa (água) foi submetida à reação com cada par das sequências dos primers utilizados.

Uma vez confirmada a integridade das amostras e a positividade da detecção de RPL13 por RT-PCR, a quantificação da expressão de Scnn1a, Scnn1b e Scnn1g foi realizada por meio de reações de Real Time PCR, utilizando-se Sensi mix Hi-Rox SYBR Green (Bioline) no Sistema de Real-Time RT-PCR ViiATM7 (Applied Biosystems) (Figura 13). Os primers foram adequadamente criados a partir do programa Primer Express $\AA$ (Applied Biosystems). 
Os resultados foram analisados com base no valor de CT (threshold cicle ou ciclo limiar), sendo este o ponto correspondente ao número de ciclos onde a amplificação atinge um dado limiar, que permite a análise quantitativa da expressão do fator avaliado.

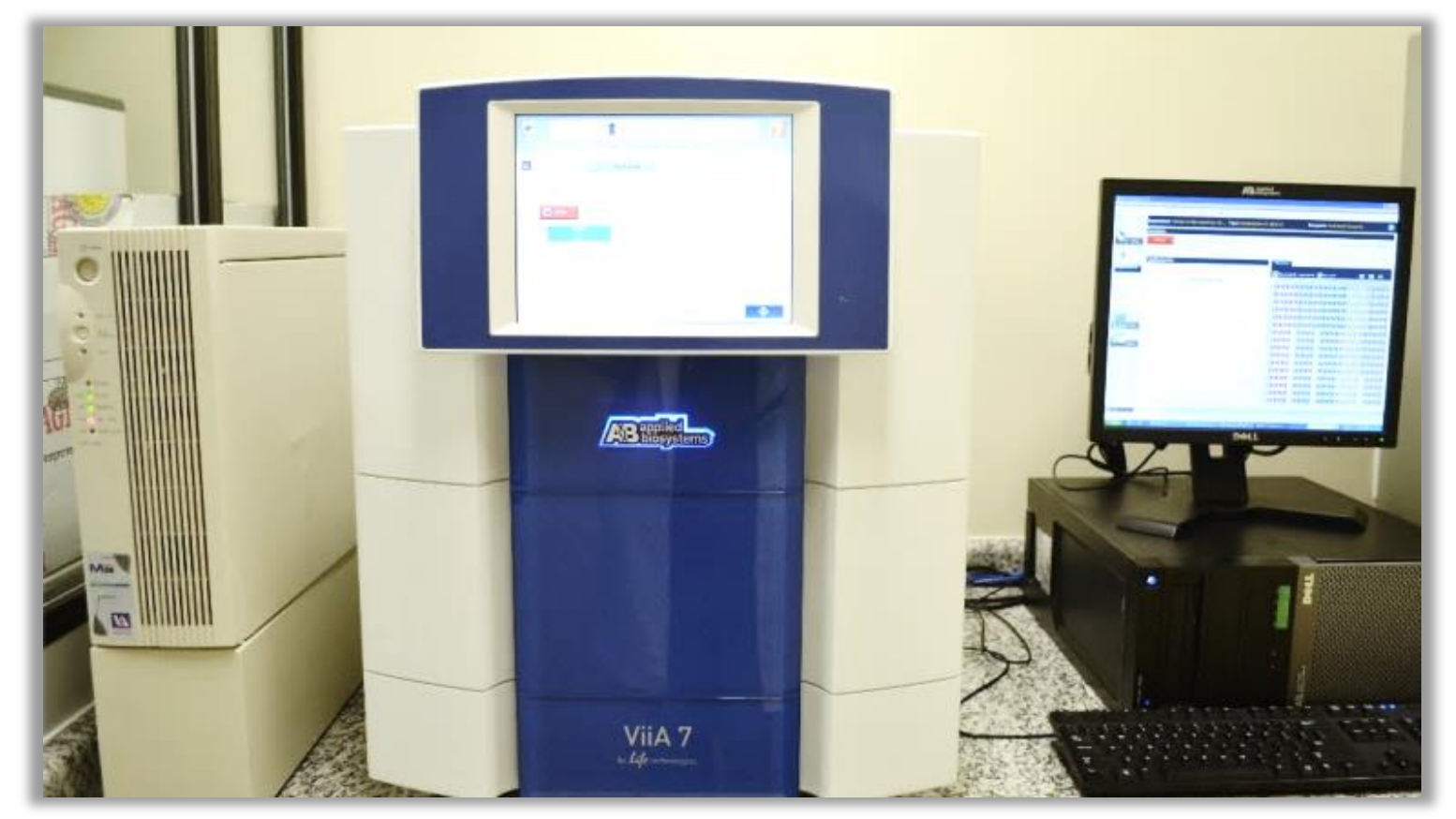

Figura 13 - Sistema de Real-Time RT-PCR ViiA ${ }^{\mathrm{TM}} 7$ (Applied Biosystems). 


\subsection{Análise Estatística}

Os resultados foram analisados utilizando o programa GraphPad Prism 5. Os grupos experimentais foram submetidos à análise de variância ANOVA One-way, seguido pelo teste de Tukey.

A significância foi dada quando $P<0,05$. Todas as amostras passaram pelo teste de normalidade de acordo com o método de Kolmogorov e Smirnov, onde o valor de $\mathrm{P}$ foi $>0,10$. 
4 Material e Métodos

$\longrightarrow$ 
5 Resultados 



\section{RESULTADOS}

\subsection{Ensaios de viabilidade celular}

Inicialmente foram feitos três experimentos independentes para cada ensaio (MTT e Cristal Violeta), onde a partir dos dados obtidos em cada um desses experimentos foi tirada a média denominada triplicata biológica.

Os resultados de viabilidade serão apresentados somente em função da triplicata biológica. Todos os grupos experimentais passaram no teste de normalidade das amostras realizado pelo teste de KS.

A análise estatística foi representada por letras nos gráficos, onde letras diferentes significam diferenças somente em relação ao grupo controle de cada tipo de tratamento ( $\mathrm{NaF}$ ou $\mathrm{NaCl}$ ).

\subsubsection{Redução do MTT}

Para comprovar e validar os resultados obtidos em cada um dos três experimentos individuais foi feita a média geral dos três ensaios de MTT a partir dos valores de absorbância de cada grupo em seu respectivo período experimental.

Desta forma, pudemos observar que em todos os períodos o tratamento com $\mathrm{NaF}$ se comportou similarmente em relação a seu efeito na viabilidade das células $\mathrm{M}-1$, levando a uma diminuição progressiva dos valores à medida que a concentração de tratamento aumentava. Sendo que as maiores concentrações, 100, 200 e $400 \mu \mathrm{M}$, levaram a uma diminuição drástica da viabilidade das células, pois, mostraram diferenças estatisticamente significativas não somente se comparadas ao grupo controle, mas também aos grupos de 10 e $40 \mu \mathrm{M}$, com exceção do período de 96 horas, no qual o grupo $40 \mu \mathrm{M}$ não apresentou diferenças significativas com o grupo $100 \mu \mathrm{M}$.

Em todos os períodos as concentrações de 10 e $40 \mu \mathrm{M}$ de $\mathrm{NaF}$ apresentaram diferenças em relação ao grupo controle e entre si. Enquanto as concentrações de 200 e $400 \mu \mathrm{M}$ não apresentaram diferenças entre si ( $p>0,05)$. No entanto, a concentração $100 \mu \mathrm{M}$ também não apresentou diferenças entre 200 e 400 $\mu \mathrm{M}$ na maioria dos períodos com exceção do período de 96 horas. 
De maneira geral foi possível observar diferenças estatisticamente significativas em todos os grupos de tratamento com $\mathrm{NaF}$ se comparados com o grupo controle nos períodos de 24, 48, 72 e 96 horas. A análise detalhada da comparação dos grupos experimentais de $\mathrm{NaF}$ em relação ao grupo controle pode ser observada no anexo 1.

Assim como com o $\mathrm{NaF}$, o efeito das concentrações de $\mathrm{NaCl}$ nas células M-1 foi similar quando comparadas as células sem tratamento (grupo controle) (Figura 14), ocorrendo diferenças estatisticamente significativas em todos os períodos. A comparação entre os grupos das concentrações de $\mathrm{NaCl}$ também apresentou diferenças, sendo que a concentração $10 \mu \mathrm{M}$ apresentou diferença estatisticamente significante com todas as outras concentrações no decorrer do tempo. Já a concentração de $40 \mu \mathrm{M}$ apresentou diferenças significativas com a maioria dos grupos nos respectivos períodos, exceto com o grupo $100 \mu \mathrm{M}$ em $48 \mathrm{e}$ 96 horas, onde os valores comparados se mostraram insignificantes, com $p>0,05$ para todas as comparações.

Nos períodos 48, 72 e 96 horas as concentrações 100, 200 e $400 \mu \mathrm{M}$ de $\mathrm{NaCl}$ não apresentaram diferenças estatisticamente significativas entre si. Em 24 horas somente a concentração $100 \mu \mathrm{M}$ se comportou diferentemente mostrando diferenças com a concentração $400 \mu \mathrm{M}$.

Nas Figuras 15 e 16 fica evidente que tanto para $\mathrm{NaF}$ quanto para $\mathrm{NaCl}$ as maiores concentrações levaram a uma diminuição dos valores de absorbância. Em contrapartida, os períodos de tempo de exposição ao tratamento não exerceram influência sobre as células, visto que, os períodos experimentais não apresentaram diferença estatisticamente significante quando comparados entre si. A tendência no gráfico se manteve similar para os períodos de 24, 48, 72 e 96 horas em todas as concentrações e inclusive no grupo controle.

Inicialmente propomos mostrar que o $\mathrm{Na}^{+}$conjugado ao halogênio $\mathrm{F}$ não tende a interferir no efeito que $F$ possa exercer sobre as células renais $M-1$, em virtude disso, os achados no ensaio de MTT mostraram que os grupos experimentais de $\mathrm{NaF}$ não apresentaram diferenças estatisticamente significativas se comparado com os grupos de $\mathrm{NaCl}$ nos mesmos períodos e nas mesmas concentrações (anexo 2). 


\section{Resultados}

O grupo controle de $\mathrm{NaF}$ também não sofreu variação estatística quando comparado como grupo controle de $\mathrm{NaCl}$, mostrando uma boa replicabilidade durante o plaqueamento das células. 


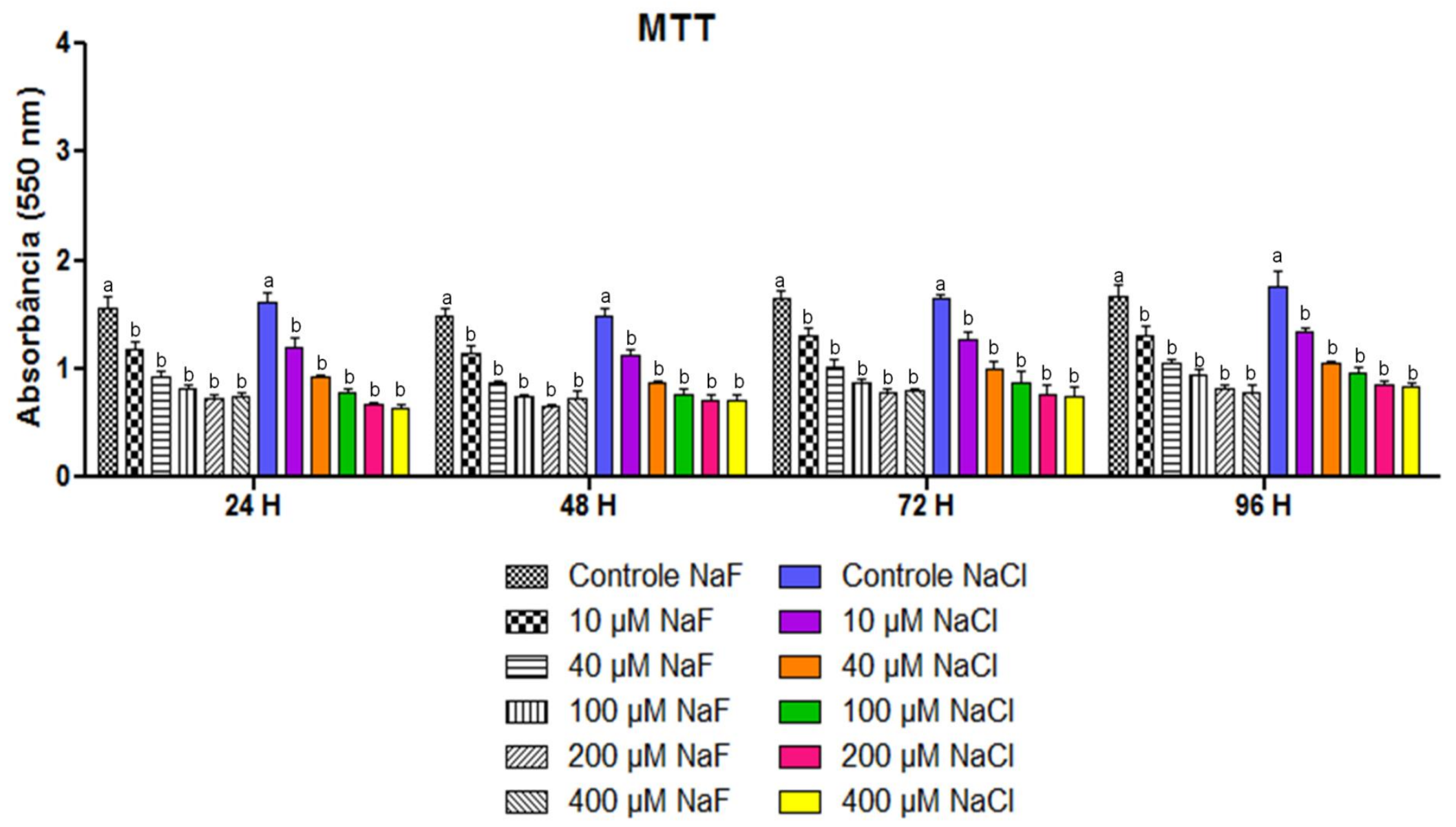

Figura 14 - Efeito das concentrações 10, 40, 100, 200 e $400 \mu \mathrm{M}$ de NaF e NaCl sobre a viabilidade de células da linhagem M-1. Estes resultados são referentes aos valores de absorbância obtidos pelo ensaio redução do MTT. Os valores são expressos em média \pm desvio padrão. Letras diferentes indicam diferenças estatísticas $(p<0,05)$ em relação ao grupo controle. 


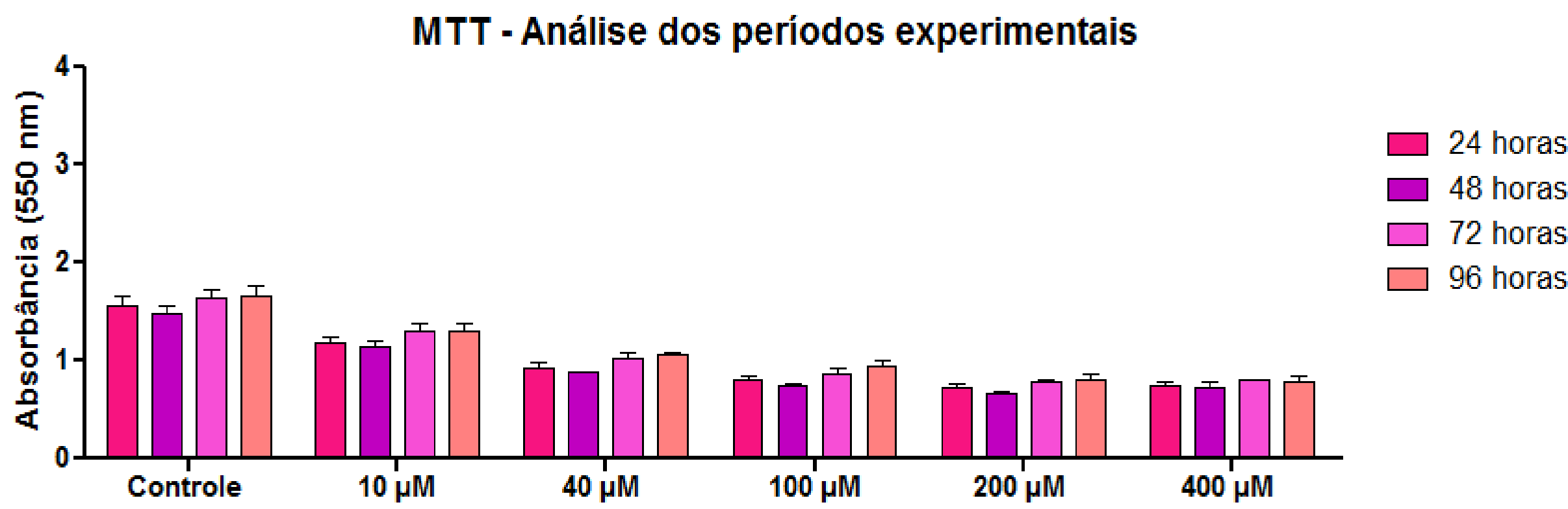

\section{Concentrações NaF}

Figura 15 - Efeito das concentrações 10, 40, 100, 200 e $400 \mu \mathrm{M}$ de NaF sobre a viabilidade de células da linhagem M-1. Estes resultados são referentes

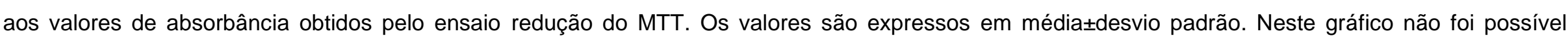
observar diferenças entre os períodos de tempo dentro de um grupo experimental, visto que, os períodos não apresentaram diferença estatisticamente significativa entre si $(p<0,05)$. 


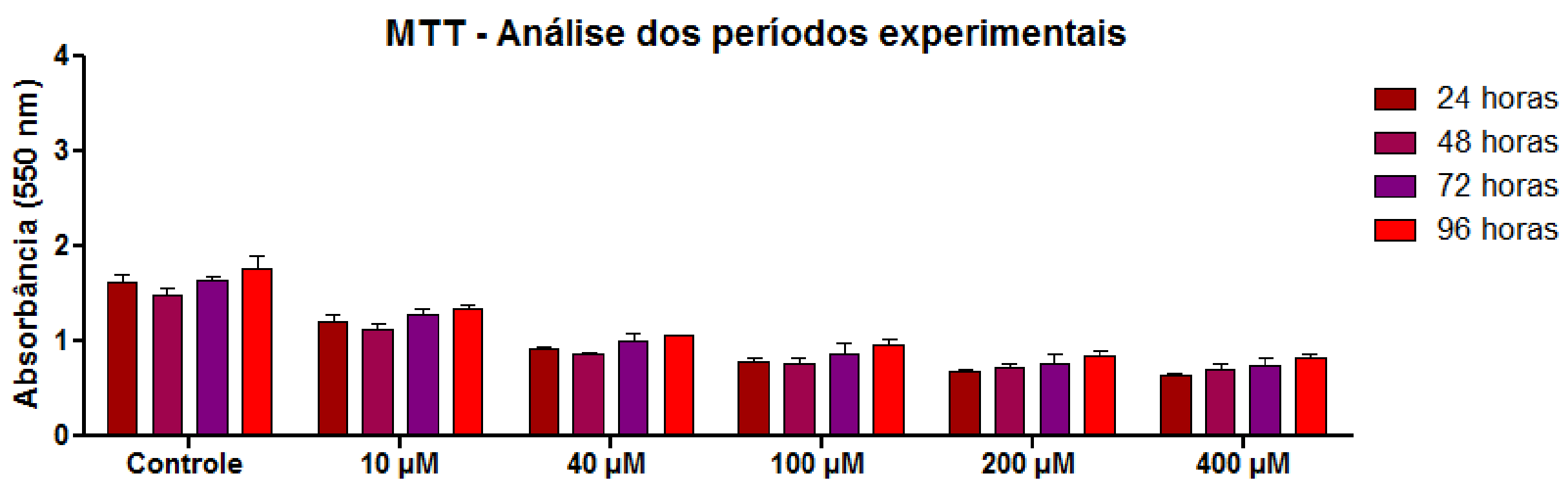

\section{Concentrações $\mathrm{NaCl}$}

Figura 16 - Efeito das concentrações 10, 40,100, 200 e $400 \mu \mathrm{M}$ de $\mathrm{NaCl}$ sobre a viabilidade de células da linhagem M-1. Estes resultados são referentes aos valores de absorbância obtidos pelo ensaio redução do MTT. Os valores são expressos em média \pm desvio padrão. Neste gráfico não foi possível observar diferenças entre os períodos de tempo dentro de um grupo experimental, visto que, os períodos não apresentaram diferença estatisticamente significativa entre si $(p<0,05)$. 


\subsubsection{Cristal Violeta}

O ensaio Cristal Violeta avalia diferentes parâmetros do ensaio MTT. Portanto diferenças entre os resultados de Cristal Violeta e MTT não são incomuns. Assim como no ensaio MTT, três experimentos independentes com Cristal Violeta foram realizados para que fosse obtida a média geral dos valores de absorbância e com isso delinear os acontecimentos nas células em resposta aos tratamentos de maneira confiável.

A partir da análise da triplicata biológica do ensaio Cristal Violeta (Figura 17), podemos apontar as concentrações de $\mathrm{NaF}$ mais relevantes estatisticamente em comparação com o grupo controle. Foram elas: 200 e $400 \mu \mathrm{M}$ no período de 48 horas, 200 e $400 \mu \mathrm{M}$ no período de 72 horas e 40, 100, 200 e $400 \mu \mathrm{M}$ no período de 96 horas. No período de 24 horas nenhum grupo tratado com $\mathrm{NaF}$ apresentou diferenças estatisticamente significantes com o grupo sem tratamento (controle).

A resposta da viabilidade celular nas concentrações 10,40 e $100 \mu \mathrm{M}$ de $\mathrm{NaF}$ se conduziu similarmente nos períodos de 48 e 72 horas, não demonstrando diferença estatística significativa com o grupo controle em cada período. A única concentração de $\mathrm{NaF}$ que revelou não provocar diminuição da viabilidade celular em todos os períodos foi a concentração de $10 \mu \mathrm{M}$.

Analisando a Figura 18 não é possível estabelecer uma relação entre diminuição da viabilidade celular a medida que a concentração de NaF aumenta. No entanto, foi possível constatar que a resposta celular não variou em função do tempo, visto que, não pudemos observar diferenças estatisticamente significativas entre os períodos de tempo que os grupos experimentais foram analisados.

$\mathrm{Na}$ análise entre as concentrações de $\mathrm{NaF}$, não foi possível observar grandes diferenças comparando-se os valores de absorbância das concentrações de $\mathrm{NaF}$ entre si no decorrer do tempo. Em 24 horas apenas a concentração $40 \mu \mathrm{M}$ apresentou diferença estatística relevante quando comparada com $100 \mu \mathrm{M}$, já em 48 horas a concentração $400 \mu \mathrm{M}$ revelou ser a mais díspar estatisticamente, apresentando diferenças com o grupo 10 e $40 \mu \mathrm{M}$. Além disso, neste mesmo período o grupo $10 \mu \mathrm{M}$ apresentou valores de absorbância com diferenças estatísticas significativas com o grupo $200 \mu \mathrm{M}$. 
Em 72 horas as diferenças estatisticamente relevantes encontradas entre os grupos foram novamente entre $400 \mu \mathrm{M}$ e as menores concentrações de 10 e 40 $\mu \mathrm{M}$ de NaF, e também com o grupo $100 \mu \mathrm{M}$. Por fim, no período de 96 horas os valores de absorbância dos grupos 200 e 400 MM mostraram desproporção com a concentração $10 \mu \mathrm{M}$, apresentando diferença estatística. Fica evidente que as maiores concentrações de $\operatorname{NaF}(100,200$ e $400 \mu \mathrm{M})$ quase sempre não apresentam diferenças entre si, mas parecem divergir constantemente com as concentrações de 10 e $40 \mu \mathrm{M}$.

O efeito das concentrações de $\mathrm{NaCl}$ sobre a viabilidade das células $\mathrm{M}-1$ equiparado as células sem tratamento, foi deveras observado somente em 24 e 48 horas, visto que os períodos de 72 e 96 horas não apresentaram diferenças estatisticamente significativa entre os grupos incluindo o grupo controle.

Premeditadamente as maiores concentrações de $\mathrm{NaCl}$ continuaram apresentando diferenças expressivas em comparação ao grupo controle, manifestando-se desta vez nos períodos de 24 e 48 horas, onde os valores de absorbância das concentrações de 100, 200 e $400 \mu \mathrm{M}$ distinguiram-se estatisticamente dos valores do grupo controle.

Todas as concentrações de tratamento com $\mathrm{NaCl}$ não mostraram diferença estatisticamente significativa entre si, por outro lado, os períodos experimentais apresentaram diferenças estatísticas entre si (Figura 19) e o padrão das diferenças se manteve para todos os grupos experimentais, mostrando ser um fator importante para a elucidação do comportamento celular em relação aos tratamentos com $\mathrm{NaCl}$. De maneira geral, as diferenças estatísticas nos períodos experimentais foram observadas entre 24 e 48 horas, 24 e 96 horas e 48 e 72 horas.

As comparações entre os valores de absorbância dos tratamentos $\mathrm{NaF}$ e $\mathrm{NaCl}$, desta vez obtidos pelo ensaio Cristal Violeta, revelaram insignificância estatística na maioria das comparações, lembrando que as comparações foram feitas somente entre os mesmos grupos, por exemplo: $40 \mu \mathrm{M}$ de $\mathrm{NaCl}$ x $40 \mu \mathrm{M}$ de NaF. No entanto, nos períodos de 48 e 72 horas foi possível observar diferença estatisticamente significativa entre $\mathrm{NaF}$ e NaCl na concentração de $400 \mu \mathrm{M}$.

A análise completa das diferenças entre os tratamentos e as diferenças entre $\mathrm{NaF}$ e $\mathrm{NaCl}$, referentes ao ensaio Cristal Violeta, se encontram nos anexos 3 e 4. 


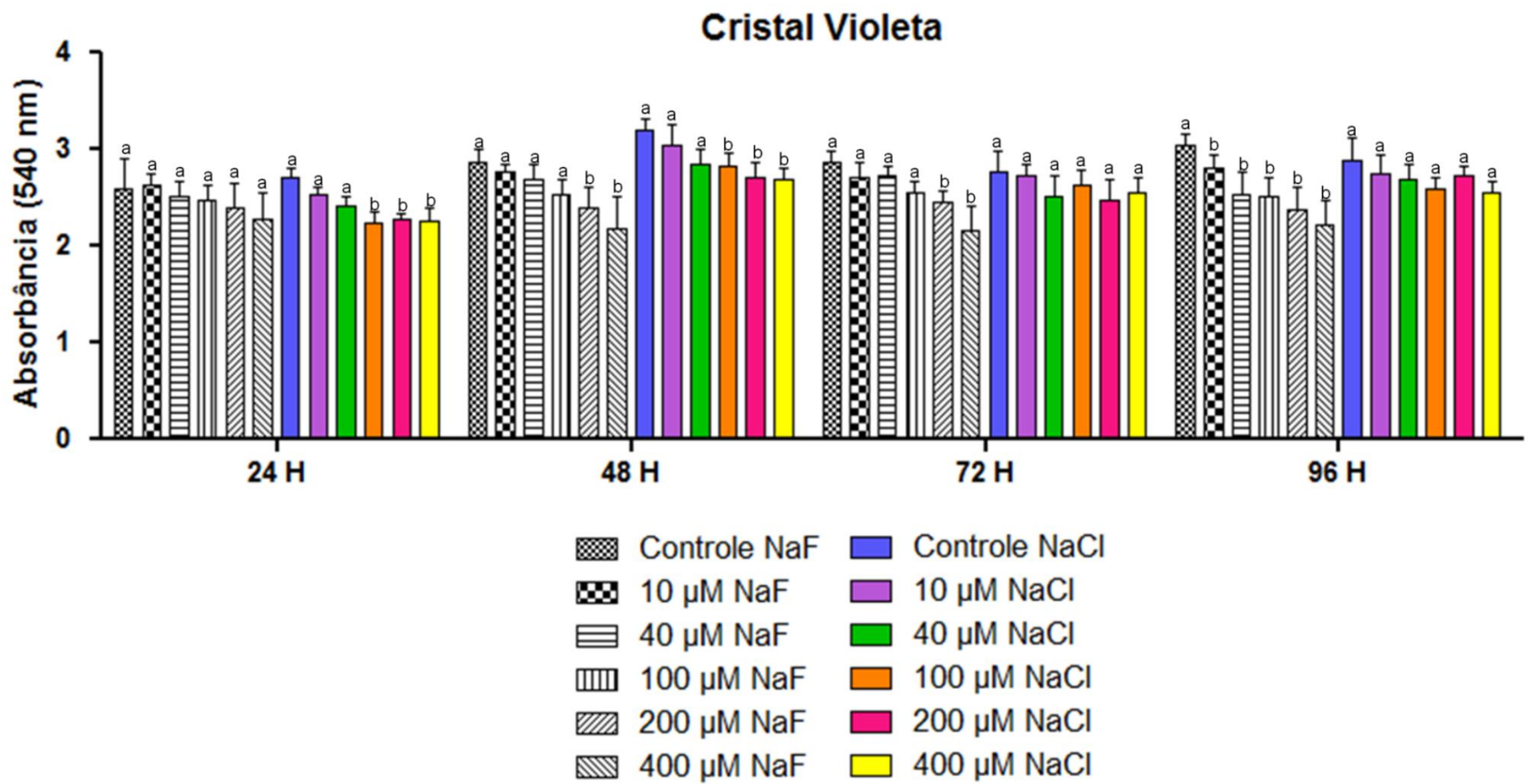

Figura 17 - Efeito das concentrações 10, 40, 100, 200 e $400 \mu \mathrm{M}$ de NaF e NaCl sobre a viabilidade de células da linhagem M-1 nos períodos de 24, 48, 72 396 horas. Estes resultados são referentes aos valores de absorbância obtidos pelo ensaio Cristal Violeta. Os valores são expressos em média \pm desvio padrão. Letras diferentes indicam diferenças estatísticas $(p<0,05)$ em relação ao grupo controle. 


\section{Cristal Violeta - Análise dos períodos experimentais}

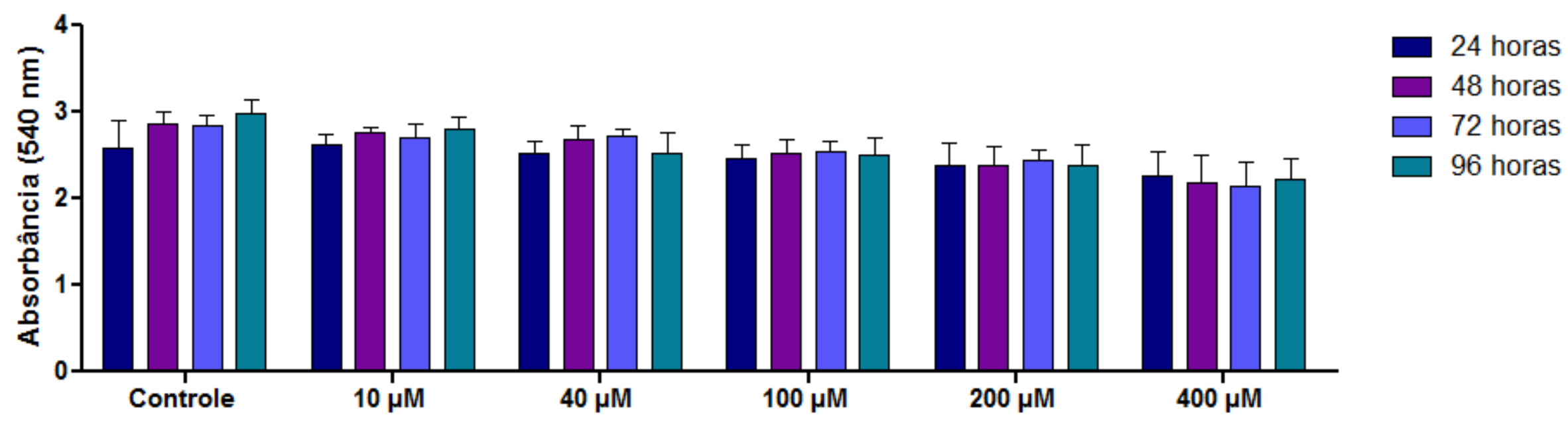

\section{Concentrações $\mathrm{NaF}$}

Figura 18 - Efeito das concentrações 10, 40, 100, 200 e $400 \mu \mathrm{M}$ de NaF sobre a viabilidade de células da linhagem M-1. Estes resultados são referentes

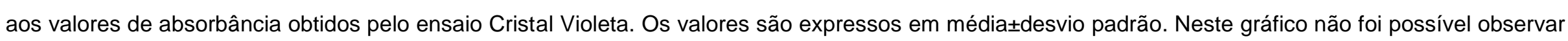
diferenças entre os períodos de tempo dentro de um grupo experimental, visto que, os períodos não apresentaram diferença estatisticamente significativa entre si $(p<0,05)$. 


\section{Cristal Violeta - Análise dos períodos experimentais}

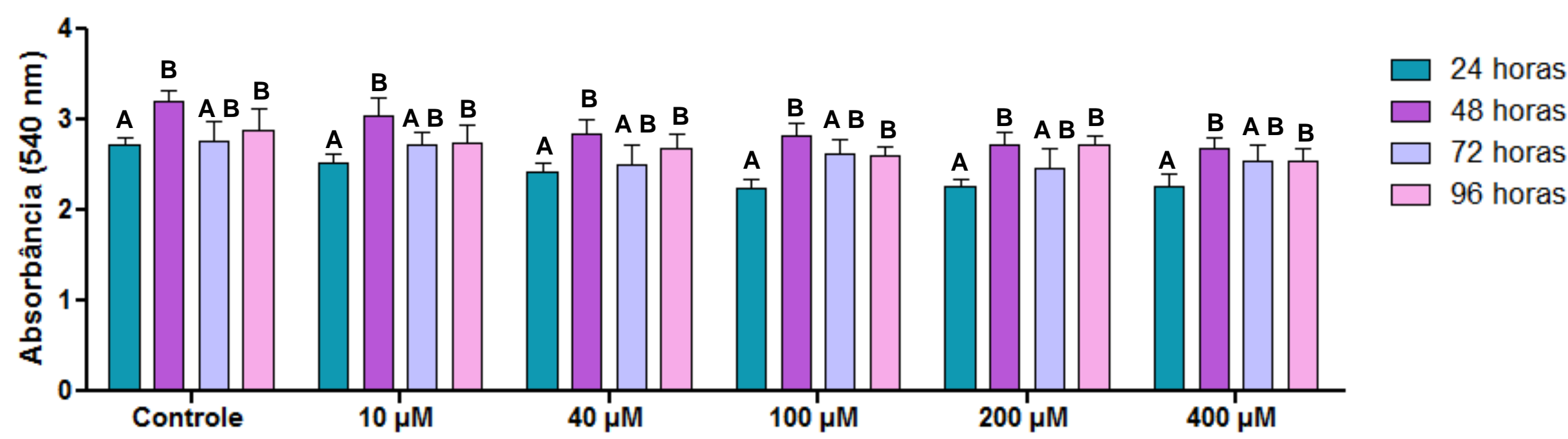

Concentrações $\mathrm{NaCl}$

Figura 19 - Efeito das concentrações 10, 40, 100, 200 e $400 \mu \mathrm{M}$ de $\mathrm{NaCl}$ sobre a viabilidade de células da linhagem M-1. Estes resultados são referentes aos valores de absorbância obtidos pelo ensaio Cristal Violeta. Os valores são expressos em média \pm desvio padrão. Neste gráfico somente as letras em maiúsculo iguais não apresentam diferenças estatisticamente significativas entre os períodos de tempo dentro de um grupo experimental $(p<0,05)$. 
A partir dos resultados obtidos com os ensaios de viabilidade pudemos verificar quais foram as concentrações de maior interesse de estudo, visto que, algumas concentrações manifestaram efeitos mais drásticos sobre a viabilidade das células do que outras, desta maneira, optamos pela escolha de concentrações com maior relevância entre os grupos, bem como, delineamos novos períodos de experimentação, visto que, de acordo com a maioria dos experimentos anteriores o fator tempo não esteve diretamente relacionado com diminuição da viabilidade, mas sim a dose.

Para a continuidade das novas etapas de análises foram escolhidas apenas três concentrações de tratamento e dois períodos experimentais, que são: as concentrações 100, 200 e $400 \mu \mathrm{M}$ e os períodos de 24 e 48 horas. 


\subsection{Imunofluorescência}

Todas as imagens de imunofluorescência adquiridas foram organizadas pelos seus respectivos grupos experimentais, período experimental em que se encontrava e tipo de alvo (subunidade alfa ou gama). Nas figuras 21 a 24 é possível observar o delineamento feito para a aquisição das imagens, além disso, em cada grupo, foi adotado um total de quatro campos adquiridos no aumento de 40X para a realização da quantificação da intensidade de fluorescência pelo programa AxioVision (Zeiss).

Todos os valores obtidos na quantificação da intensidade de fluorescência foram expressos em gráficos de coluna. Para a análise qualitativa deste ensaio, uma imagem de cada grupo marcado foi adquirida no aumento de 60X a fim de revelar possíveis diferenças no âmbito da distribuição de marcação individual e conjunta das células frente os tratamentos, lembrando que cada imagem no aumento de $60 \mathrm{X}$ foi adquirida concomitantemente as imagens do tamanho de 40X. As figuras 25 a 28 mostram os gráficos de coluna e as imagens em maior aumento.

Tanto nos grupos tratados com NaF, quanto nos grupos tratados com $\mathrm{NaCl}$, não foi possível observar um padrão na intensidade de marcação com o decorrer do tempo. Os valores encontrados levaram a uma grande oscilação dos grupos, inclusive o grupo controle, que muitas vezes apresentou valores de intensidade de marcação bem abaixo dos grupos tratados. Desta forma não foi possível correlacionar intensidade de marcação com aumento ou diminuição da distribuição das subunidades alfa e gama dos canais entre os grupos. Analisando qualitativamente as imagens, foi possível observar que houve vasta marcação das subunidades alfa e gama em todos os grupos para ambos tratamento, quando comparado as imagens do grupo controle negativo.

Além disso, foi possível observar o aparecimento da conformação de "domes" celular em diversos grupos, inclusive nos de células tratadas com concentrações de $400 \mu \mathrm{M}$ de $\mathrm{NaF}$ ou $\mathrm{NaCl}$, e mesmo nestas concentrações não foi possível observar profundas mudanças na morfologia das células com o passar do tempo. 


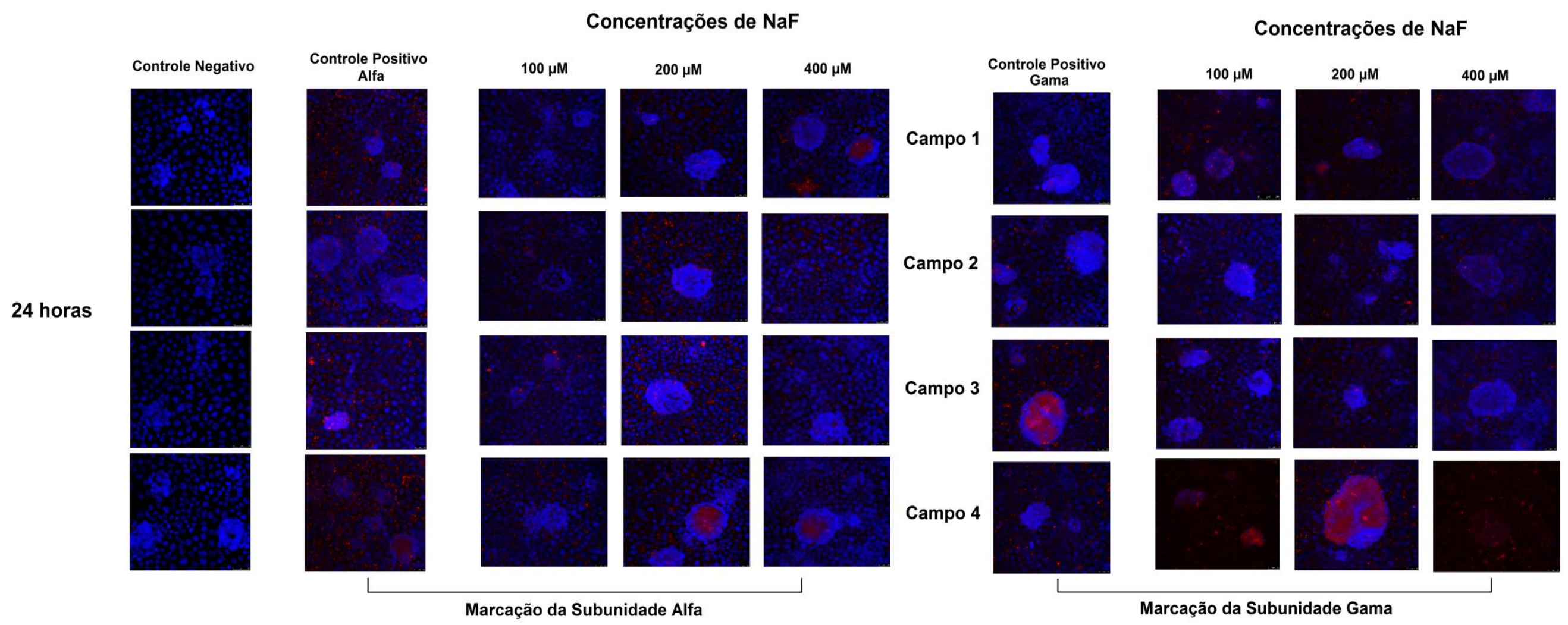

Figura 20 - Imagens adquiridas por microscopia confocal a laser, no aumento de 40 X, mostrando a marcação dos alvos Alfa e Gama, separadamente, nos grupos tratados com as concentrações de 100, 200 e $400 \mu \mathrm{M}$ de NaF, bem como nos grupos controle positivo (sem tratamento), no período de 24 horas. $O$ grupo controle negativo (sem marcação) foi empregado a fim de mostrar que não houve reação cruzada entre o anticorpo secundário (conjugado com PE) e as células. 
Concentrações de $\mathrm{NaCl}$

Controle Negativo
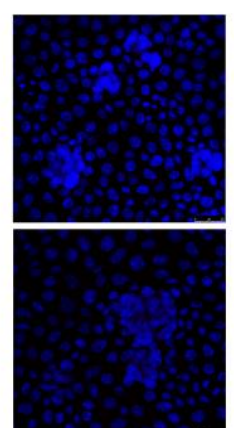

24 horas
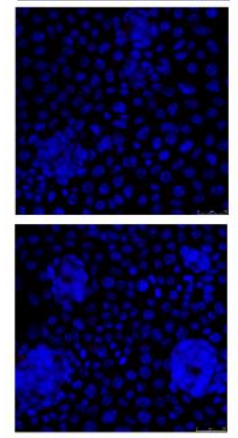

Controle Positivo

Alfa
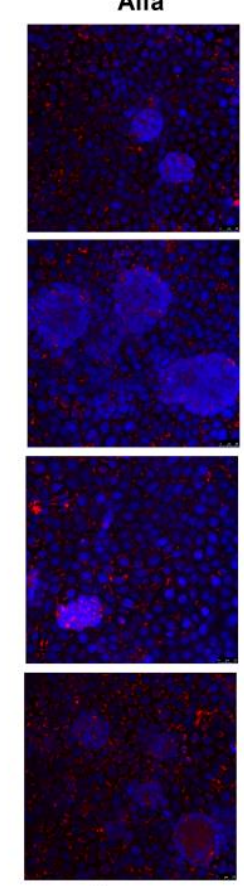

$100 \mu \mathrm{M}$
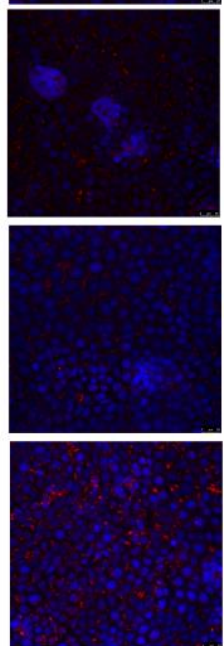

Marcação da Subunidade Alfa
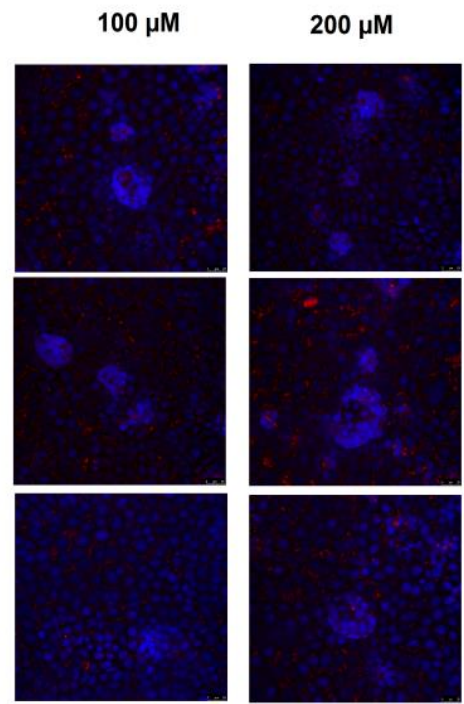

Concentrações de $\mathrm{NaCl}$
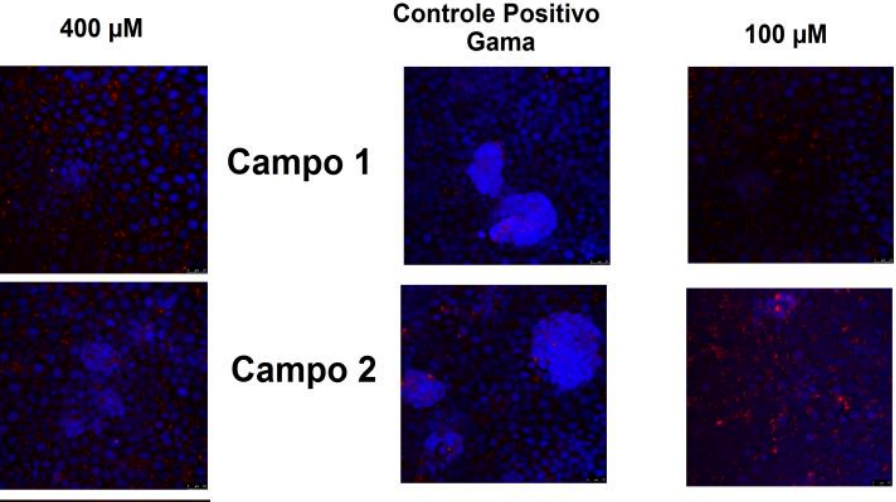

$200 \mu \mathrm{M}$

$400 \mu \mathrm{M}$
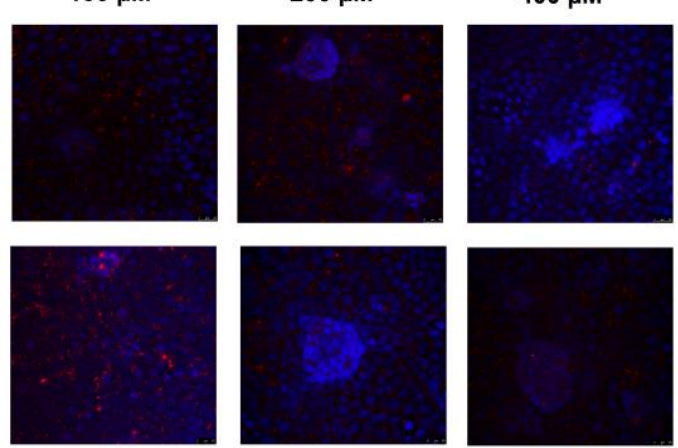

Campo 3
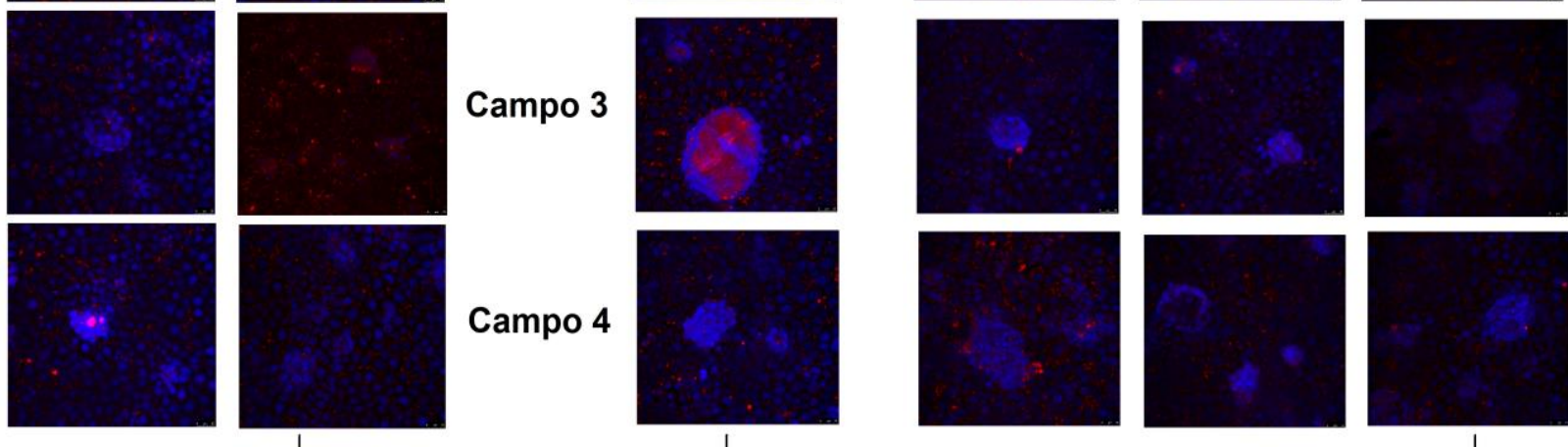
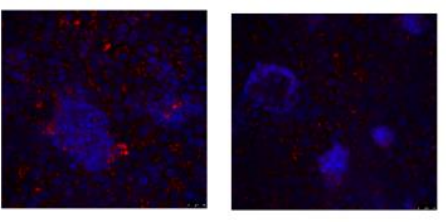

Marcação da Subunidade Gama

Figura 21 - Imagens adquiridas por microscopia confocal a laser, no aumento de 40 X, mostrando a marcação dos alvos Alfa e Gama, separadamente, nos grupos tratados com as concentrações de 100, 200 e $400 \mu \mathrm{M}$ de NaCl, bem como nos grupos controle positivo (sem tratamento), no período de 24 horas. $\mathrm{O}$ grupo controle negativo (sem marcação) foi empregado a fim de mostrar que não houve reação cruzada entre o anticorpo secundário (conjugado com PE) e as células. 


\section{Concentrações de NaF}

Controle Negativo
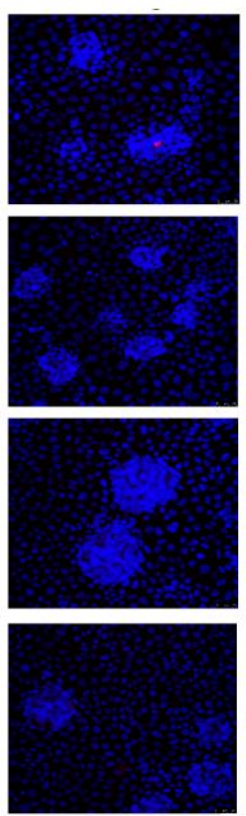
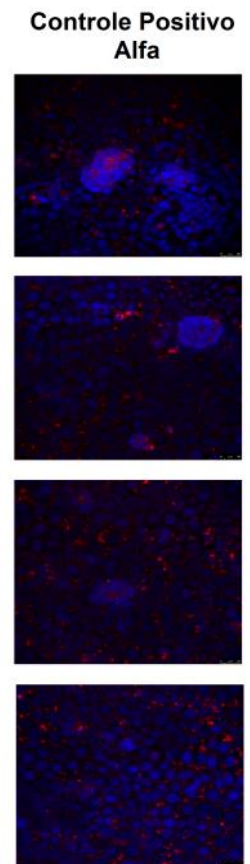

L
$100 \mu \mathrm{M}$
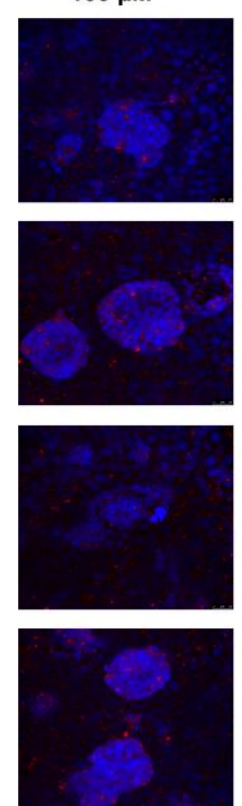

Marcação da Subunidade Alfa
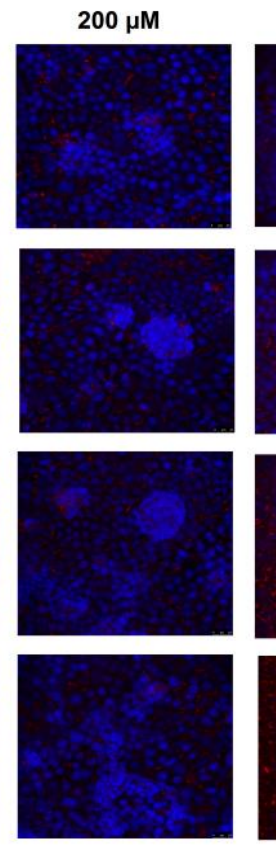

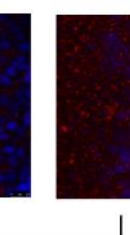

$400 \mu \mathrm{M}$
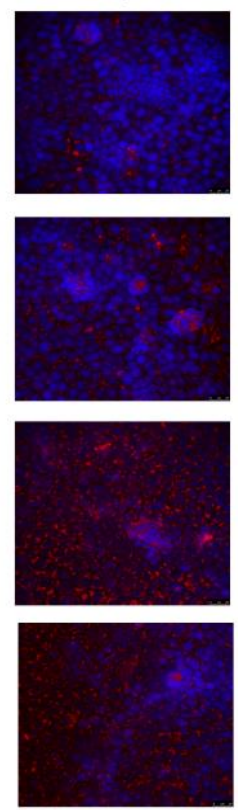

Concentrações de NaF

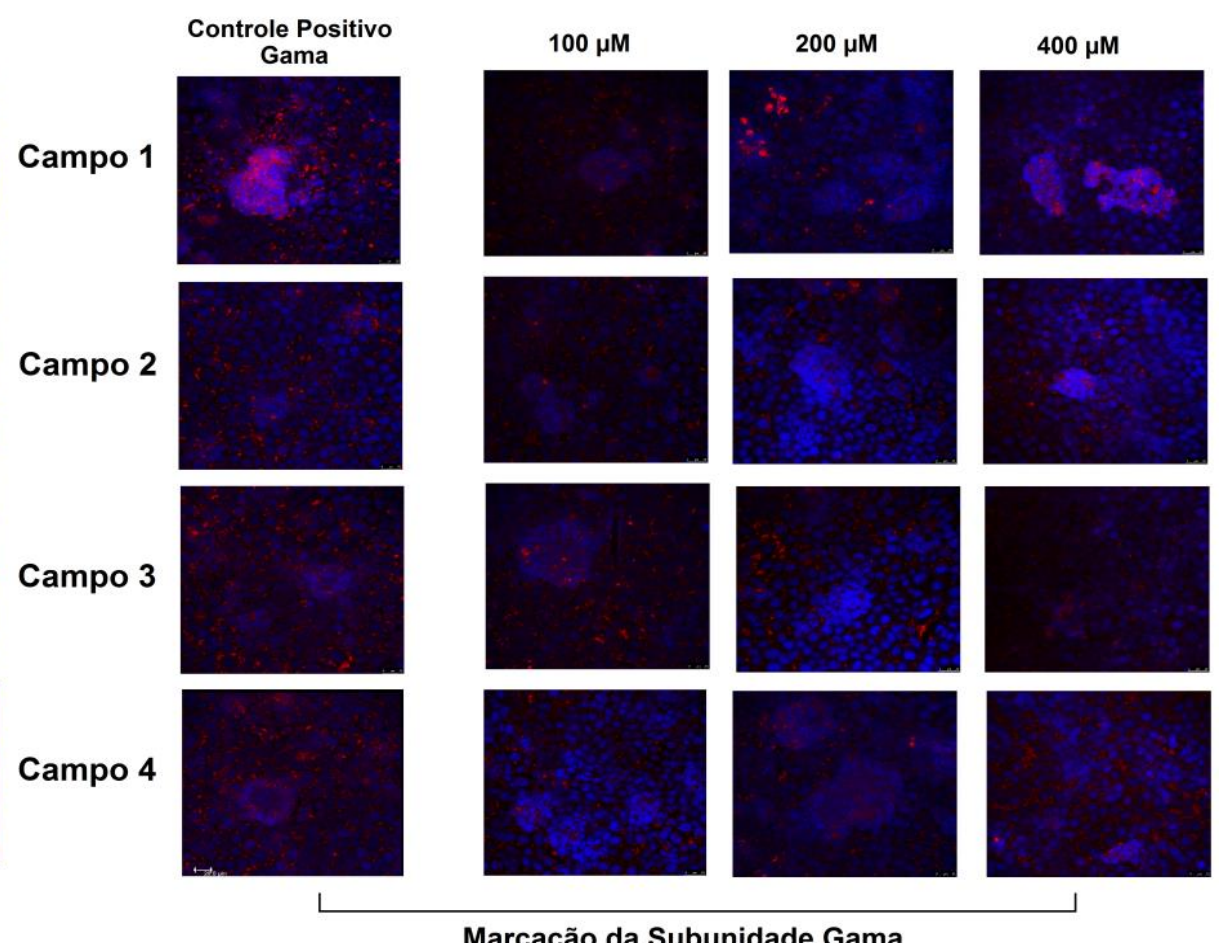

Marcação da Subunidade Gama

Figura 22 - Imagens adquiridas por microscopia confocal a laser, no aumento de $40 \mathrm{X}$, mostrando a marcação dos alvos Alfa e Gama, separadamente, nos grupos tratados com as concentrações de 100, 200 e $400 \mu \mathrm{M}$ de NaF, bem como nos grupos controle positivo (sem tratamento), no período de 48 horas. $O$ grupo controle negativo (sem marcação) foi empregado a fim de mostrar que não houve reação cruzada entre o anticorpo secundário (conjugado com PE) e as células. 


\section{Concentrações de $\mathrm{NaCl}$}
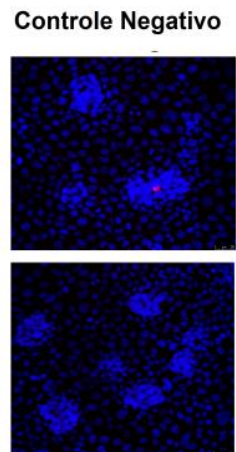

48 horas
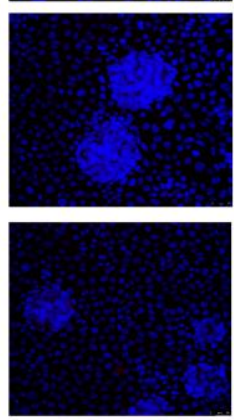
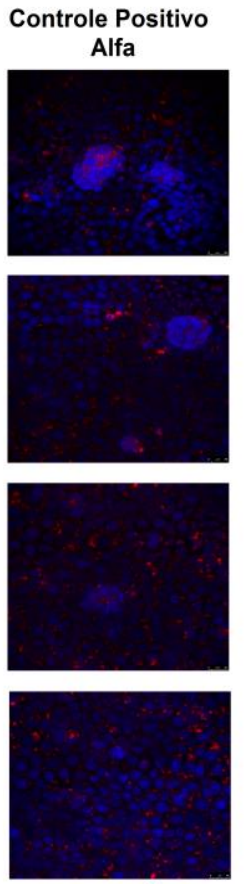

$100 \mu \mathrm{M}$
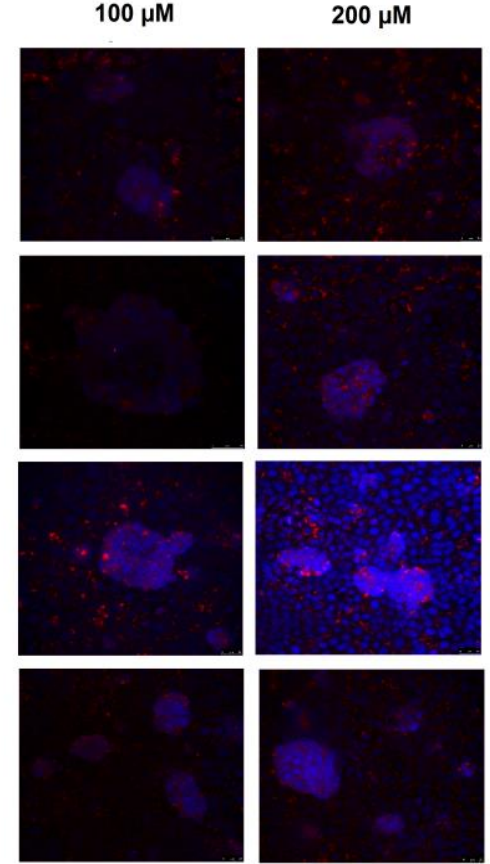

Marcação da Subunidade Alfa

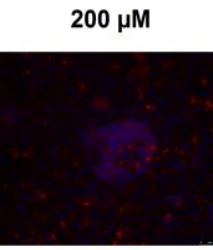

Concentrações de $\mathrm{NaCl}$
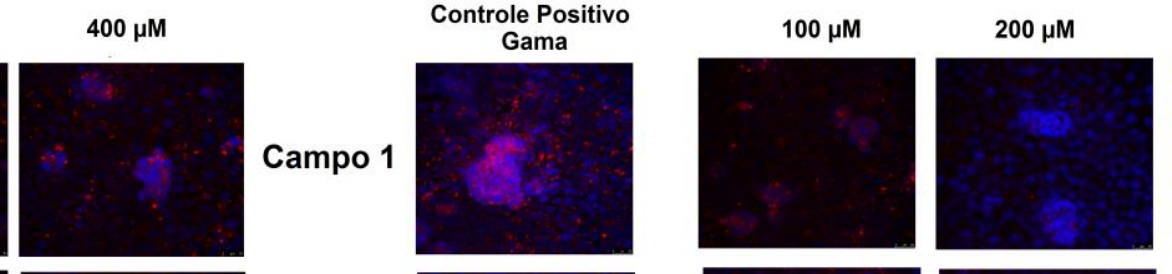

$400 \mu \mathrm{M}$

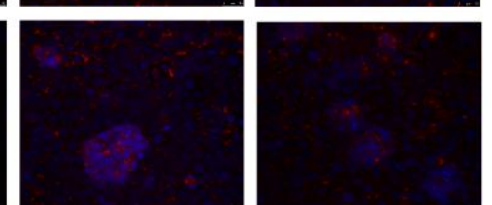

Campo 2
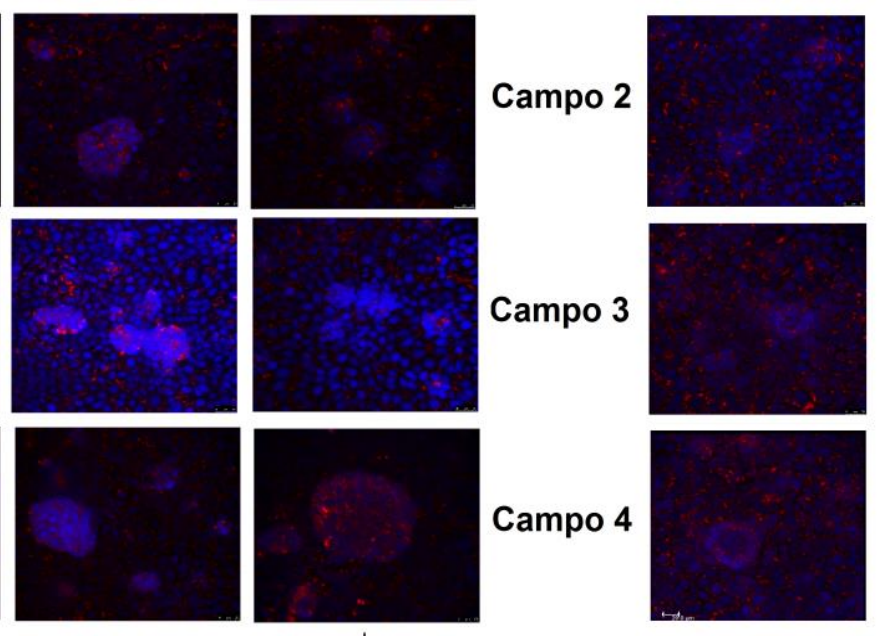

1
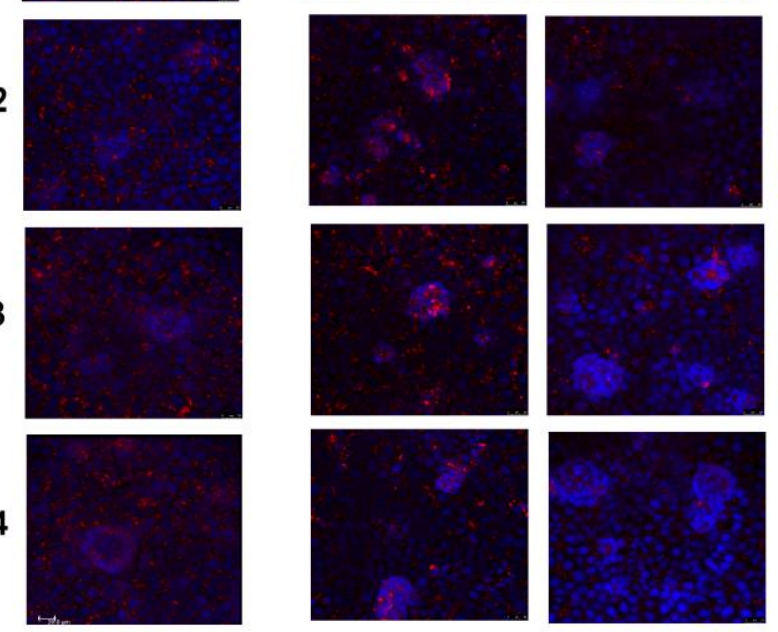

Marcação da Subunidade Gama

Figura 23 - Imagens adquiridas por microscopia confocal a laser, no aumento de $40 \mathrm{X}$, mostrando a marcação dos alvos Alfa e Gama, separadamente, nos grupos tratados com as concentrações de 100, 200 e $400 \mu \mathrm{M}$ de NaCl, bem como nos grupos controle positivo (sem tratamento), no período de 48 horas. O grupo controle negativo (sem marcação) foi empregado a fim de mostrar que não houve reação cruzada entre o anticorpo secundário (conjugado com PE) e as células. 
24 horas

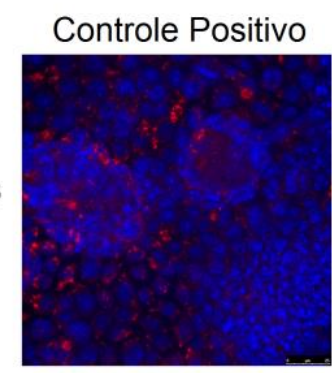

$100 \mu \mathrm{M} \mathrm{NaF}$
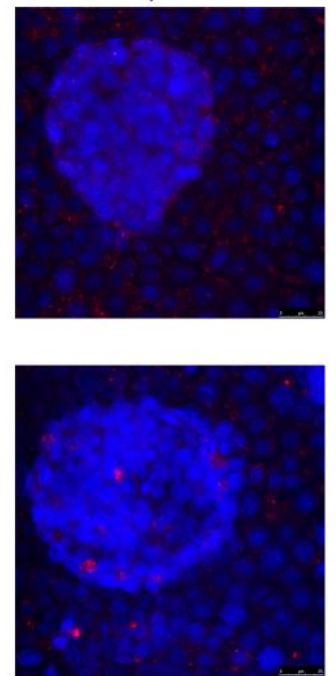

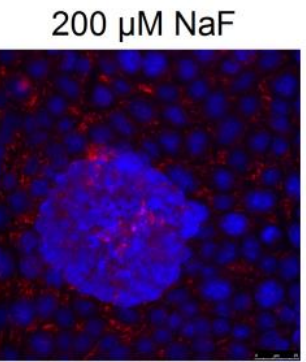

$400 \mu \mathrm{M} \mathrm{NaF}$
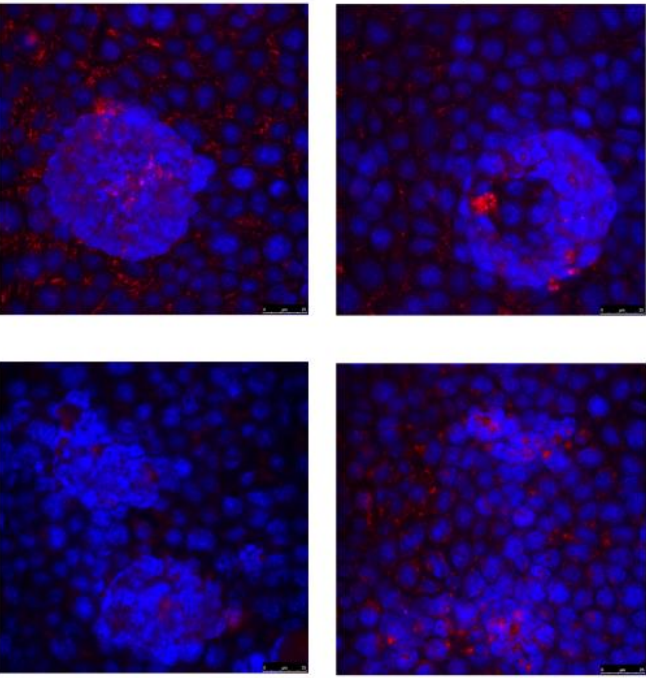

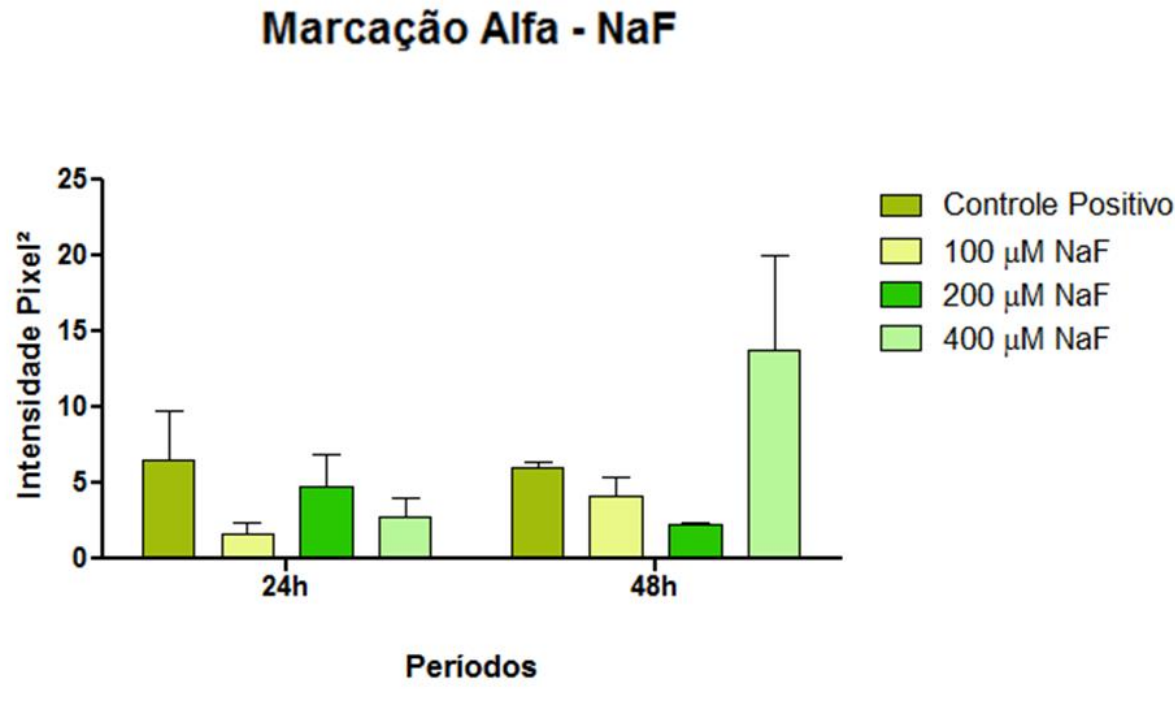

Figura 24 - Imagens dos grupos experimentais tratados com NaF e grupo controle adquiridas no aumento de 60X por microscopia confocal a laser, nos períodos de 24 e 48 horas, e gráfico de colunas mostrando a intensidade da marcação do alvo subunidade Alfa nos mesmos períodos e grupos experimentais. 


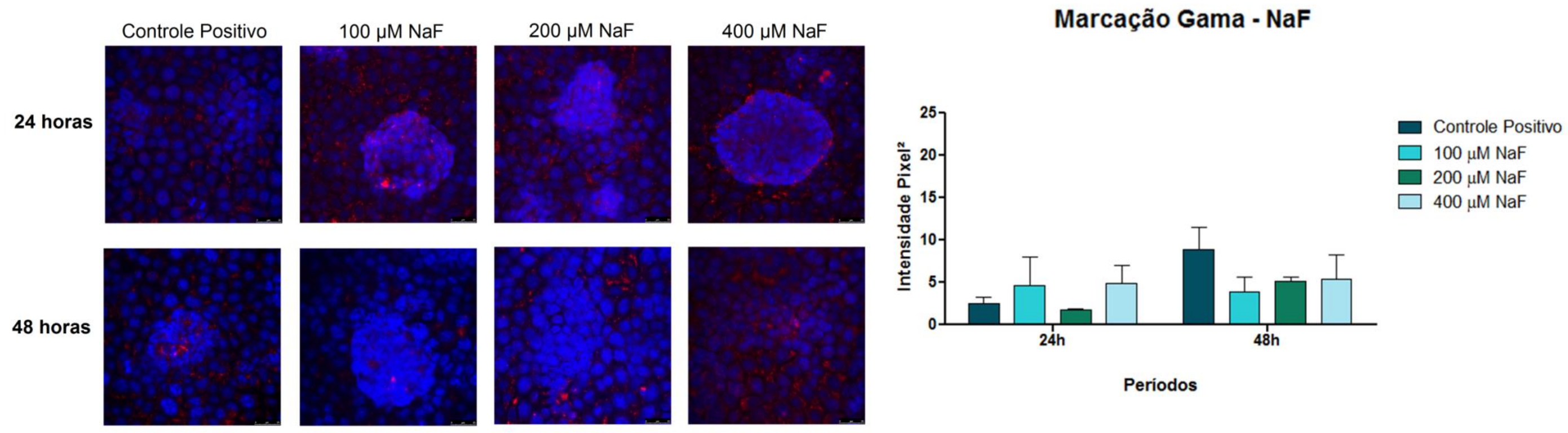

Figura 25 - Imagens dos grupos experimentais tratados com NaF e grupo controle adquiridas no aumento de 60X por microscopia confocal a laser, nos períodos de 24 e 48 horas, e gráfico de colunas mostrando a intensidade da marcação do alvo subunidade Gama nos mesmos períodos e grupos experimentais. 

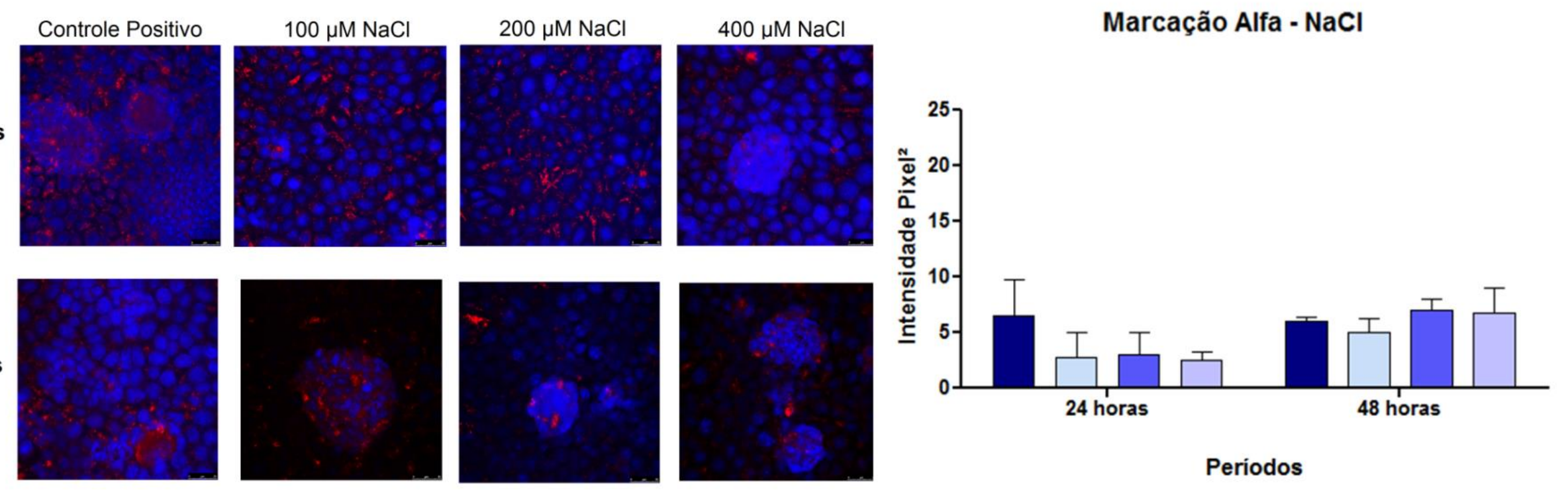

- Controle positivo

$\square 100 \mu \mathrm{M} \mathrm{NaCl}$

$200 \mu \mathrm{M} \mathrm{NaCl}$

$400 \mu \mathrm{M} \mathrm{NaCl}$

Períodos

Figura 26 - Imagens dos grupos experimentais tratados com NaCl e grupo controle adquiridas no aumento de 60X por microscopia confocal a laser, nos períodos de 24 e 48 horas, e gráfico de colunas mostrando a intensidade da marcação do alvo subunidade Alfa nos mesmos períodos e grupos experimentais. 


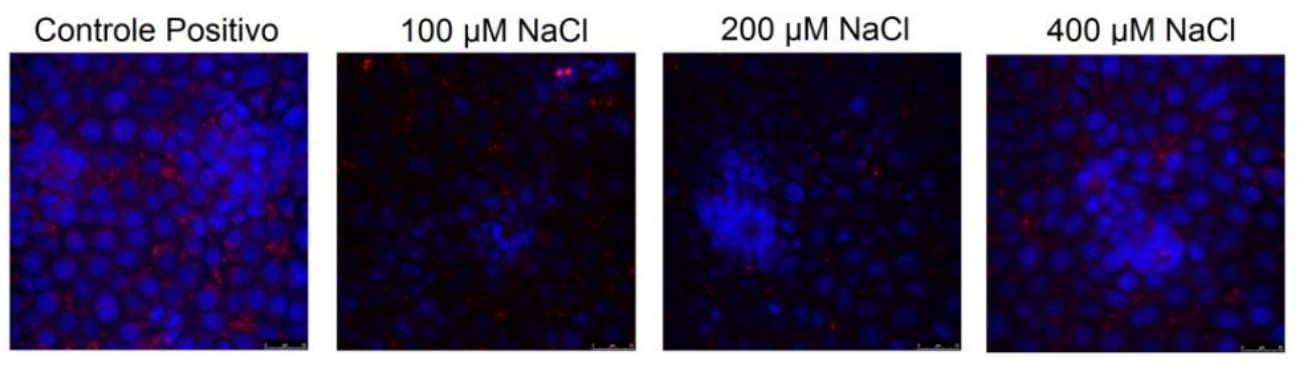

48 horas
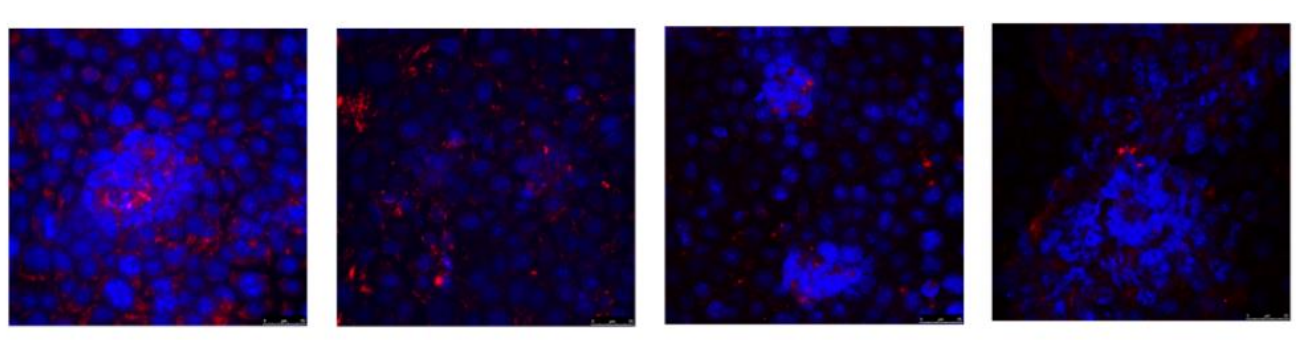

Marcação Gama - NaCl

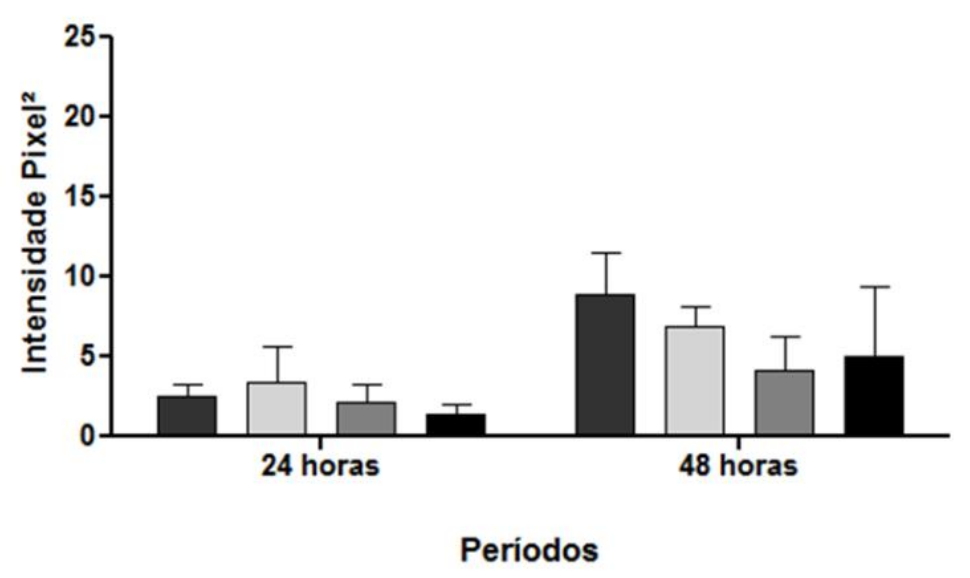

Figura 27 - Imagens dos grupos experimentais tratados com NaCl e grupo controle adquiridas no aumento de 60X por microscopia confocal a laser, nos períodos de 24 e 48 horas, e gráfico de colunas mostrando a intensidade da marcação do alvo subunidade Gama nos mesmos períodos e grupos experimentais. 


\subsection{RT-PCR}

A convenção para a nomenclatura de genes que codificam as subunidas do canal de sódio epitelial, em camundongos, começa com uma letra maiúscula seguida de todas as letras minúsculas (GIRALDEZ et al., 2012).

\subsubsection{Efeito das diferentes concentrações de $\mathrm{NaF}$ na expressão gênica da subunidade Alfa (Scnn1a) do Canal de Sódio Epitelial}

O ensaio de RT-PCR mostrou que o gene Scnn1a foi modulado diferentemente nos períodos de 24 e 48 horas pela exposição ao NaF (Figura 29). Em geral a expressão relativa de Scnn1a apresentou progressão no decorrer do tempo, tendo sua expressão aumentada no período de 48 horas. Em 24 horas, os níveis de expressão gênica nos grupos tratados com 100 e $200 \mu \mathrm{M}$ apresentaram diferenças significativas em relação ao controle. Sendo que nestas concentrações foi observado aumento da expressão gênica, em contrapartida, o grupo $400 \mu \mathrm{M}$ não apresentou diferenças com o grupo controle.

No período de 48 horas, as concentrações 100 e $200 \mu \mathrm{M}$ de $\mathrm{NaF}$ modularam positivamente a expressão de Scnn1a, pois não apresentaram diferenças estatisticamente significativas com o grupo controle, em contrapartida a concentração $400 \mu \mathrm{M}$ inibiu a expressão gênica.

As diferenças observadas apenas entre os grupos de tratamento com $\mathrm{NaF}$ mostraram que tanto em 24 quanto em 48 horas a concentração $400 \mu \mathrm{M}$ apresentou diferenças estatísticas significantes em comparação com as concentrações 100 e $200 \mu \mathrm{M}$, esta análise pode ser observada no anexo 5 .

\subsubsection{Efeito das diferentes concentrações de NaF na expressão gênica da subunidade Beta (Scnn1b) do Canal de Sódio Epitelial}

O perfil geral da expressão de Scnn1b nos 2 períodos mostrou-se semelhante ao perfil de Scnn1a, apresentando como única diferença o fato do grupo controle, em 24 horas, não apresentar diferenças estatisticamente significativas com as concentrações 100 e $200 \mu \mathrm{M}$ de NaF (Figura 30). 
A concentração $400 \mu \mathrm{M}$ de NaF continuou modulando negativamente a expressão gênica, levando a uma drástica queda no espectro em ambos os períodos de tempo. $O$ aumento da expressão de Scnn1b foi novamente observado com o decorrer do tempo, sendo que os maiores espectros da expressão gênica ocorreram no período de 48 horas nos grupos: controle, $100 \mu \mathrm{M}$ e $200 \mu \mathrm{M}$ de tratamento com $\mathrm{NaF}$. Novamente, tanto em 24 quanto em 48 horas a concentração $400 \mu \mathrm{M}$ apresentou diferenças estatísticas significantes em comparação não somente com o grupo controle, mas também com as concentrações 100 e $200 \mu \mathrm{M}$, esta análise pode ser observada no anexo 7 .

\subsubsection{Efeito das diferentes concentrações de $\mathrm{NaF}$ na expressão gênica da subunidade Gama (Scnn1g) do Canal de Sódio Epitelial}

A modulação da expressão do gene Scnn1g (Figura 31) foi positiva em 24 horas, na concentração $200 \mu \mathrm{M}$ e no período de 48 horas, na concentração de $100 \mu \mathrm{M}$. Onde ocorreram aumentos da expressão gênica e inclusive apresentaram diferenças estatisticamente significativas com o grupo controle. A concentração de $400 \mu \mathrm{M}$ de NaF mais uma vez levou a diminuição da expressão gênica, e a comparação dos grupos de tratamento apresentaram diferenças entre si em 48 horas, esta análise poder ser observada no anexo 9. 


\section{Scnn1a}

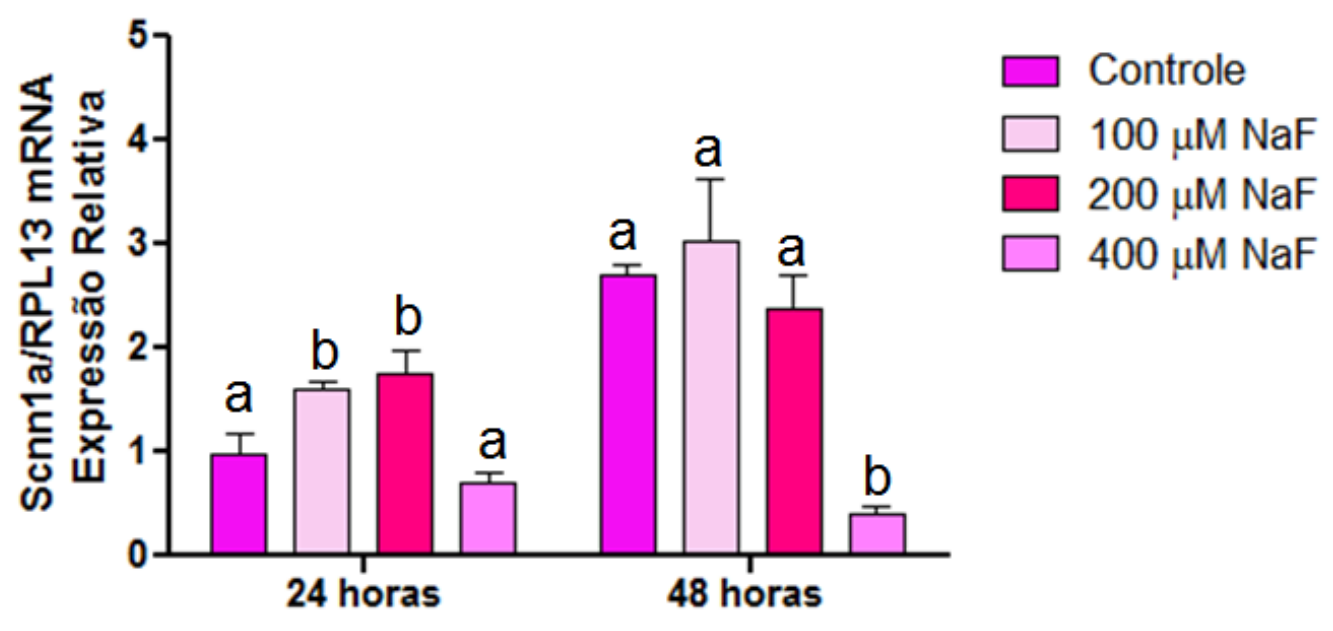

Periodos

Figura 28 - Efeito das concentraçoes 100, 200 e $400 \mu \mathrm{M}$ de NaF na expressão gênica de Scnn1a em células epiteliais renais $\mathrm{M}-1$. Letras diferentes representam diferenças estatísticas em relação ao grupo controle.

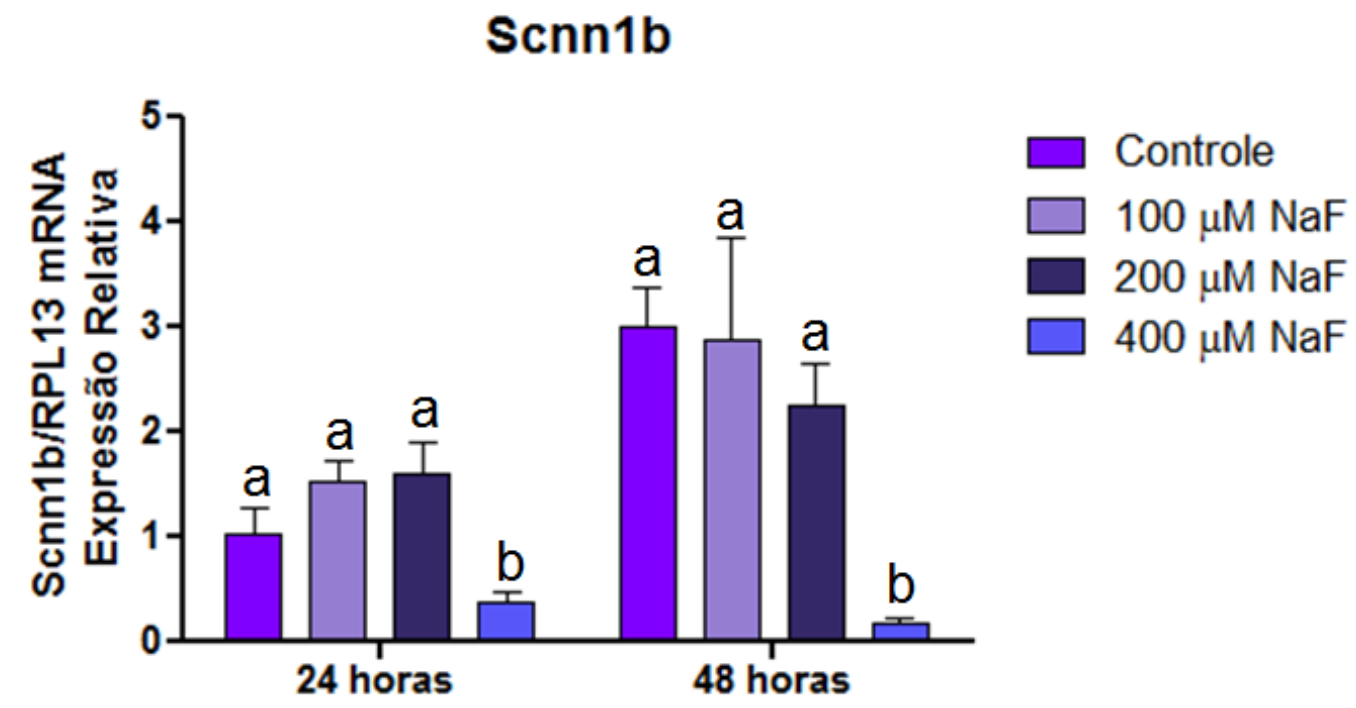

\section{Períodos}

Figura 29 - Efeito das concentraçoes 100, 200 e $400 \mu \mathrm{M}$ de NaF na expressão gênica de Scnn1b em células epiteliais renais $M-1$. Letras diferentes representam diferenças estatísticas em relação ao grupo controle. 


\section{Scnn1g}

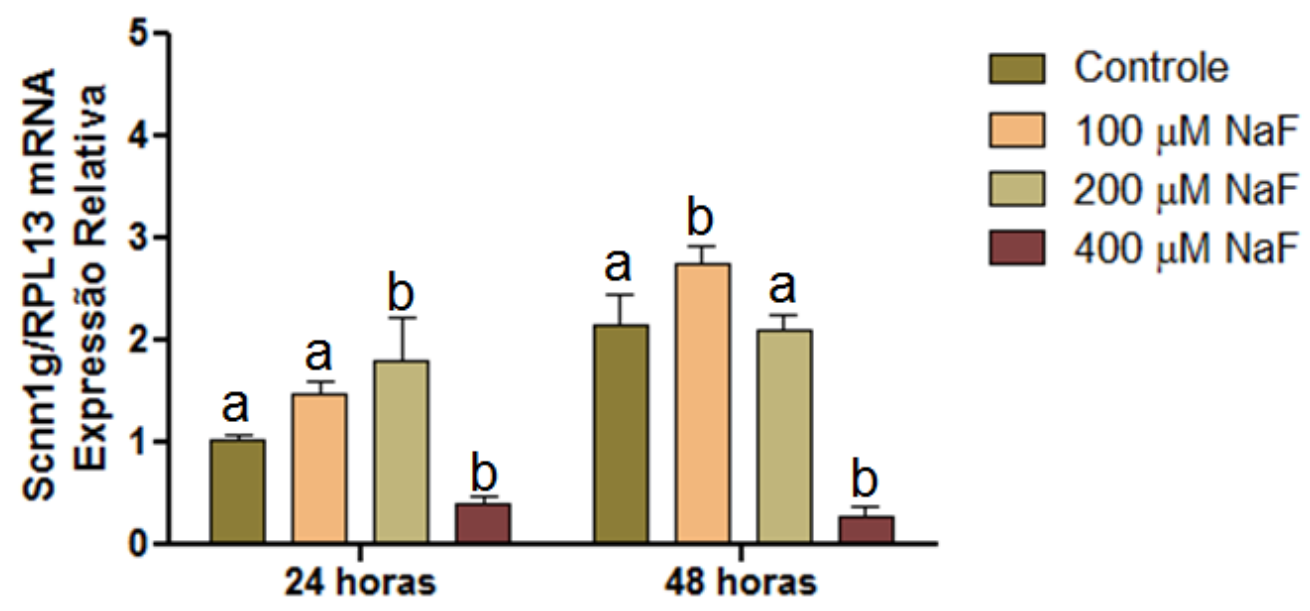

\section{Periodos}

Figura 30 - Efeito das concentraçoes 100, 200 e $400 \mu \mathrm{M}$ de NaF na expressão gênica de Scnn1g em células epiteliais renais $\mathrm{M}-1$. Letras diferentes representam diferenças estatísticas em relação ao grupo controle. 


\section{Discussão}





\section{DISCUSSÃO}

Sabe-se que o $\mathrm{F}$ exerce diversos efeitos sobre as células, estes efeitos vão depender do tempo, da concentração e do tipo celular (BARBIER et al., 2010). O principal efeito do $F$ nas células consiste em sua interação com enzimas. Na maioria dos casos, o $\mathrm{F}$ atua como um inibidor enzimático, mas os íons $\mathrm{F}$ podem ocasionalmente estimular a atividade enzimática (ADAMEK et al., 2005).

Em relação aos nossos resultados, pudemos observar nitidamente, por meio do ensaio de redução de MTT, que todas as concentrações de tratamento com $\mathrm{NaF}$ diminuíram a viabilidade das células $\mathrm{M}-1$ se comparadas as células não tratadas. No entanto, não foram encontradas diferenças significantes quando comparadas com as mesmas concentrações e períodos dos tratamentos com $\mathrm{NaCl}$.

$\mathrm{O}$ motivo de $\mathrm{NaCl}$ ter apresentado as mesmas respostas que $\mathrm{NaF}$ pode ter sido pelo fato de que as mitocôndrias são os principais alvos intracelulares para diferentes estressores, incluindo flúor Desta maneira $\mathrm{NaCl}$ estaria atuando como um agente estressor da mitocôndria apesar de estar presente em concentrações altas nos fluídos extracelulares, e tratando-se de células muito ricas em mitocôndrias, como as renais. Isso pode ter contribuído para acentuar o efeito de $\mathrm{NaCl}$ na diminuição da viabilidade celular observado no ensaio MTT (ANURADHA; KANNO; HIRANO, 2001; CITTANOVA et al., 1996 ). No estudo de Kobayashi, et al., (2009) especulou-se que efeitos hipertônicos renais, frente ao tratamento de animais com $50 \mathrm{ppm}$ de $\mathrm{NaF}$, poderia ser atribuído à presença de $\mathrm{Na}^{+}$no sal $\mathrm{NaF}$, no entanto, o mesmo efeito foi relatado em ratos submetidos a anestesia com sevoflurano, um composto de $F$ orgânico que não contem sódio.

Diversos estudos mostraram que o $\mathrm{F}$ exerce diferentes efeitos sobre a maquinaria celular levando à morte celular, apoptose e/ou necrose in vivo e in vitro (BARBIER et al., 2010). No entanto, não foi possível estabelecer uma relação entre diminuição da viabilidade celular e efeito do $F$ por meio de algum destes mecanismos, primeiramente por que não foram observadas profundas mudanças estruturais entre as células dos grupos tratados, além disso, os resultados obtidos com o ensaio Cristal Violeta também não puderam mostrar que exclusivamente $\mathrm{NaF}$ é capaz de diminuir a viabilidade das células, visto que algumas concentrações de 
$\mathrm{NaCl}$ em determinados períodos também levaram a diminuição da viabilidade celular.

Os íons de $\mathrm{F}$ podem se ligar a grupamentos funcionais de aminoácidos ao redor do centro ativo de uma enzima para causar um efeito de inibição, como é o caso das enzimas da via glicolítica e o ciclo de Krebs, que são sensíveis à inibição pelo fluoreto. A bomba de sódio e potássio $\left(\mathrm{Na}^{+} / \mathrm{K}^{+}\right.$-ATPases) também é inibida por $F$, levando a depleção de ATP e um distúrbio no potencial da membrana celular (ADAMEK et al., 2005).

A reabsorção de sódio no ducto coletor cortical envolve principalmente o transporte apical através do ENaC impulsionada pela atividade de $\mathrm{Na}^{+} / \mathrm{K}^{+}$ATPase basolateral (Staruschenko, 2012). Desta maneira, se a atividade de $\mathrm{Na}^{+} / \mathrm{K}^{+}$ATPase estiver comprometida pelo $\mathrm{F}$ ocorrerá mudanças na atividade de $\mathrm{ENaC}$, no entanto o trabalho de Antonio, et al., 2016 mostrou que o transporte através de $\mathrm{ENaC}$, nas células $\mathrm{M}-1$, não foi afetado após o tratamento com $1 \mathrm{mM} \mathrm{NaF}$. Desta forma, podemos inferir que se na concentração de $1 \mathrm{mM}$ de $\mathrm{NaF}$ não é possível observar mudanças de atividade nos canais poderiam estar bastante íntegros nas membranas das células. Portanto, nossos achados sugerem que os tratamentos com 100, $200 \mathrm{e}$ $400 \mu \mathrm{M}$ não interferiram na integridade no canal, pois foi observado grande quantidade de marcação das subunidades de ENaC na imunofluorescência.

Outros trabalhos mostram que o $\mathrm{F}$ atua inibindo enzimas envolvidas na produção de energia intracelular, a deficiência de energia pode levar as células renais a compensar este efeito causado por $\mathrm{F}$ usando caminhos alternativos de produção de energia (BOSCH, 1996). Desta maneira, o trabalho de Kobayashi et al. (2009), que verificou a exposição renal a doses relativamente baixas de $F$, identificou o aumento da expressão de proteínas ligadas ao metabolismo e produção de energia com o intuito de compensar os prejuízos de F. Sendo assim, isso poderia explicar porque as modificações estruturais nas células não foram tão evidentes nem mesmo na maior concentração de $F$, umas vez que as células renais estariam se esforçando para manter a produção de energia por meio de outros caminhos, sem deixar que a desregulação na produção de energia cause dano ou até mesmo morte nas células.

Sabe-se que o transporte eletrogênico de íons no epitélio das células $M-1$ consistem quase que exclusivamente no transporte de sódio através de ENaC na 
membrana apical do epitélio (ANTONIO, et al., 2016). Isso também poderia explicar a abundância de marcação em todos os grupos.

Outros achados no estudo de Antonio et al., (2016) mostraram que a inibição da formação de "domes" celular aconteceu no tratamento das células M-1 com $1 \mathrm{mM}$ de NaF. Em nossos achados a concentração mais alta tanto de $\mathrm{NaF}$ quanto de $\mathrm{NaCl}(400 \mu \mathrm{M})$ não foram capazes de inibir a formação deste agrupamento celular tão característicos nesta cultura, podendo ser observado em diversas imagens da imunofluorescência. Desta maneira, podemos inferir que nossas concentrações escolhidas não interferem (inibem) na proliferação celular.

Vários estudos indicam que o $\mathrm{F}$ tem um efeito citotóxico dependente da concentração. Por exemplo, foi observada morte celular significativa $(37 \%)$ em ameloblastos que foram tratadas por $72 \mathrm{~h}$ com $1 \mathrm{mM}$ de fluoreto (Yang et al., 2013).

Apesar de nossos resultados mostrarem que $\mathrm{NaF}$, nas concentrações escolhidas, não trouxe mudanças estruturais drásticas na morfologia celular. Isso não quer dizer que na cultura celular como um todo, essas concentrações não provoquem algum tipo de alteração, como por exemplo na densidade celular, visto que, no trabalho de Antonio et al., 2016, especificamente, o tratamento por 72 horas com $1 \mathrm{mM}$ de flúor levou a $4 \%$ de morte celular em uma cultura de baixa densidade e $20 \%$ de morte celular em alta densidade.

Os resultados obtidos no PCR foram bem esclarecedores, uma vez que as concentrações de 100 e $200 \mu \mathrm{M}$ mostraram não afetar a expressão dos canais. Pelo contrário, nessas concentrações a expressão era dobrada com o passar do tempo, ou ainda era maior que até mesmo o grupo controle, isso inclui o canal Beta $\mathrm{ENaC}$. Por outro lado, em todos genes alvo estudados, tanto em 24 quanto 48 horas a concentração de $400 \mu \mathrm{M}$ foi capaz de diminuir drasticamente a expressão das subunidades.

Os rins são os principais órgãos responsáveis pela redução dos níveis de F no plasma após a ingestão (VILLA, et al., 2010). O estudo de lano et al., (2014) relatou que os níveis de $\mathrm{F}$ nos rins mostram um efeito dose-dependente, pois os níveis de $\mathrm{F}$ aumentaram com a exposição a altas concentrações de $\mathrm{F}$ no plasma, ao passo que os níveis de $\mathrm{F}$ no fígado diminuíram, comparado com os níveis no plasma. Desta maneira, este efeito dose-dependente poderia explicar porque a expressão das subunidades de ENaC permaneciam diminuídas com o passar do 
tempo na exposição a $400 \mu \mathrm{M}$ de $\mathrm{NaF}$, ao passo que em comparação com as outras concentrações e o grupo controle a expressão das proteínas era aumentada ou até mesmo dobrada. 
7 Conclusões 



\section{CONCLUSÕES}

Baseado nos resultados obtidos, temos como conclusão que:

- Tanto $\mathrm{NaF}$ como $\mathrm{NaCl}$ são capazes de modular a viabilidade das células epiteliais renais $\mathrm{M}-1$.

- As concentrações de $\mathrm{F}$ estudadas não provocam modificações estruturais significantes nas células renais.

- Concentrações de 100 e $200 \mu \mathrm{M}$ de $\mathrm{F}$ aparentam não ter efeitos na diminuição da expressão das subunidades proteicas de $\mathrm{ENaC}$ nas células renais, uma vez que com o passar do tempo a expressão não foi diminuída.

- A concentração de $400 \mu \mathrm{M}$ de NaF promove a diminuição da expressão de todas as subunidades do canal de sódio epitelial ENaC. 
7 Conclusões 


\section{Referências}





\section{REFERÊNCIAS}

Agalakova NI, Gusev GP. Molecular Mechanisms of Cytotoxicity and Apoptosis Induced by Inorganic Fluoride. Cell Biol. 2011;12:16.

Anuradha CD, Kanno S, Hirano S. Oxidative damage to mitochondria is a preliminary step to caspase-3 activation in fluoride-induced apoptosis in HL-60 cells. Free Radic Biol Med. 2001;31(3):367-73.

Atsdr. Toxicological Profile for Fluorine, Hydrogen Fluoride and Fluorides. Agency for Toxic Substances and Disease. US Public Health Service, Registry 2003.

Baconguis I, Bohlen CJ, Goehring A, Julius D, Gouaux E. X-ray structure of acidsensing ion channel 1-snake toxin complex reveals open state of a $\mathrm{Na}(+)$-selective channel. Cell. 2014;156(4):717-29.

Baldwin, HB. The acute toxicity of sodium fluoride. J Am Chem Soc. 1899;23:517521.

Barbier O, Arreola-Mendoza L, Del Razo LM. Molecular mechanisms of fluoride toxicity. Chem Biol Interact. 2010;188(2):319-33.

Becchetti A, Malik B, Yue G, Duchatelle P, Al-Khalili O, Kleyman TR, et al. Phosphatase inhibitors increase the open probability of $\mathrm{ENaC}$ in $\mathrm{A} 6$ cells. Am $\mathrm{J}$ Physiol Renal Physiol. 2002;283(5):F1030-45.

Benigni A, Cassis P, Remuzzi G. Angiotensin II revisited: new roles in inflammation, immunology and aging. EMBO Mol Med. 2010;2(7):247-57.

Bhalla V, Hallows KR. Mechanisms of ENaC regulation and clinical implications. J Am Soc Nephrol. 2008;19(10):1845-54.

Blodgett AB, Kothinti RK, Kamyshko I, Petering DH, Kumar S, Tabatabai NM. A fluorescence method for measurement of glucose transport in kidney cells. Diabetes Technol Ther. 2011;13(7):743-51.

Bonvalent, JP. Regulation of sodium transport by steroid hormones. Kidney Int Suppl, 1998;65:49-56. 
Booth RE, Johnson JP, Stockand JD. Aldosterone. Adv Physiol Educ. 2002;26(14):8-20.

Brady HR, Brenner BM, Clarkson MR, Lieberthal W. Acute renal failure. In: Brenner BM. The kidney. Philadelphia: WB Saunders. 2000;6:1201-62.

Burt BA, Fejerskov O. Water fluoridation. In: Fejerskov O, Burt BA, Ekstrand J. Fluoride in destistry. Copenhagen, Munksgaard. 1996;2(15):275-90.

Butterworth MB. Regulation of the epithelial sodium channel (ENaC) by membrane trafficking. Biochim Biophys Acta. 2010;1802(12):1166-77.

Buzalaf MA, Cardoso, VES. Destinos do fluoreto no organismo. Fluoreto e Saúde Bucal. Bauru, 2008.

Buzalaf MAR, Cury JA; Whitford GM. Fluoride expousures and dental fluorosis: a literature review. Fac Odontol Bauru, v.9, n. 1/2, p. 1-10, 2001.

Buzalaf MA, Whitford GM. Fluoride metabolism. Monogr Oral Sci. 2011;22:20-36.

Canessa CM, Merillat AM, Rossier BC. Membrane topology of the epithelial sodium channel in intact cells. Am J Physiol. 1994;267(6 Pt 1):C1682-90.

Cárdenas-González MC, Del Razo LM, Barrera-Chimal J, Jacobo-Estrada T, LópezBayghen E, Bobadilla NA, et al. Proximal renal tubular injury in rats sub-chronically exposed to low fluoride concentrations. Toxicol Appl Pharmacol. 2013;272(3):888-94.

Cardoso L, Rösing C, Kramer P, Costa C, Costa Filho LC. Polarização da cárie em município sem água fluoretada. Cad. Saúde Pública, Rio de Janeiro. 2003;19(1): 237-243.

Carvalho JG, Leite AeL, Peres-Buzalaf C, Salvato F, Labate CA, Everett ET, et al. Renal proteome in mice with different susceptibilities to fluorosis. PLoS One. 2013;8(1):e53261.

Chattopadhyay A, Podder S, Agarwal S, Bhattacharya S. Fluoride-induced histopathology and synthesis of stress protein in liver and kidney of mice. Arch Toxicol. 2011;85(4):327-35. 
Cittanova ML, Lelongt B, Verpont MC, Geniteau-Legendre M, Wahbe F, Prie D, et al. Fluoride ion toxicity in human kidney collecting duct cells. Anesthesiology. $1996 ; 84(2): 428-35$.

Dangelo JG, Fanttini, CA. Anatomia humana sistêmica e segmentar. 2. ed. São Paulo: Atheneu; 2006.

Darman RB, Flemmer A, Forbush B. Modulation of ion transport by direct targeting of protein phosphatase type 1 to the $\mathrm{Na}-\mathrm{K}-\mathrm{Cl}$ cotransporter. J Biol Chem. $2001 ; 276(37): 34359-62$.

De La Rosa DA, Canessa CM, Fyfe GK, Zhang P. Structure and regulation of amiloridesensitive sodium channels. Annu. Rev. Physiol. 2000;62:573-94.

Dote T, Kono K, Usuda K, Nishiura H, Tagawa T, Miyata K, et al. Toxicokinetics of intravenous fluoride in rats with renal damage caused by high-dose fluoride exposure. Int Arch Occup Environ Health. 2000;73 Suppl:S90-2.

Edelheit O, Hanukoglu I, Dascal N, Hanukoglu A. Identification of the roles of conserved charged residues in the extracellular domain of an epithelial sodium channel $(\mathrm{ENaC})$ subunit by alanine mutagenesis. Am J Physiol Renal Physiol. 2011;300(4):F887-97.

Edmunds WM, Smedley PL. Groundwater geochemistry and health: an overview. In: Appleton, Fuge, McCall. Environmental Geochemistry and Health. Geol Soc Spec Pub. 1996;113:91-105.

Ekstrand, J. Fluoride Metabolism. Fluoride in Dentistry. Copenhagen, Munksgaard, 1996.

Ekstrand J, Spak CJ, Vogel G. Pharmacokinetics of fluoride in man and its clinical relevance. J Dent Res. 1990;69 Spec No:550-5; discussion 6-7.

Ellwood RP, Fejerskov O, Cury JA, Clarkson B. Fluoride in caries control. In: Fejerskov O, Kidd E. Dental caries: The disease and its clinical management. Oxford: Blackwell \& Munksgaard. 200;82:287-323.

Everett ET. Fluoride's effects on the formation of teeth and bones, and the influence of genetics. J Dent Res. 2011;90(5):552-60. 
Farley JR, Wergedal JE, Baylink DJ. Fluoride directly stimulates proliferation and alkaline phosphatase activity of bone-forming cells. Science. 1983;222(4621):330-2.

Fejerskov O, Richards A, Denbesten P. The effect of fluoride on tooth mineralization In: Fejerskov O, Ekstrand, Burt BA. Fluorides in Dentistry, 2nd Ed Munksgaard pub,1996.

Féraille E, Doucet A. Sodium-potassium-adenosinetriphosphatase-dependent sodium transport in the kidney: hormonal control. Physiol Rev. 2001;81(1):345-418.

Freshney I. Culture of Animal Cells: A Manual of Basic Technique and Specialized Applications. Wiley-Blackwell 2010;7.

Fry BW, Taves DR, Merin RG. Fluorometabolites of methoxyflurane: serum concentrations and renal clearances. Anesthesiology. 1973;38(1):38-44.

Garty H, Palmer LG. Epithelial sodium channels: function, structure, and regulation. Physiol Rev. 1997;77(2):359-96.

Giraldez T, Rojas P, Jou J, Flores C, Alvarez de la Rosa D. The epithelial sodium channel $\delta$-subunit: new notes for an old song. Am J Physiol Renal Physiol. 2012;303(3):F328-38.

Gomez-Sanche, CE. Primary aldosteronism and its variants. Cardiovasc Res. 1998;37:8-13.

Gutknecht J, Walter A. Hydrofluoric and nitric acid transport through lipid bilayer membranes. Biochim Biophys Acta. 1981;644(1):153-6.

Jacinto-Aleman LF, Hermandez-Guerrero C, Trejo C. In vitro effect of sodium fluoride on antioxidative enzymes and apoptosis during murine odontogenesis. J Oral Path and Med. 2010;39(9):709-14.

Janckila AJ, Woodford TA, Lam KW, Li CY, Yam LT. Protein-tyrosine phosphatase activity of hairy cell tartrate-resistant acid phosphatase. Leukemia. 1992;6(3):199203.

Jasti J, Furukawa H, Gonzales EB, Gouaux E. Structure of acid-sensing ion channel 1 at 1.9 A resolution and low $\mathrm{pH}$. Nature. 2007;449(7160):316-23. 
Kashlan OB, Sheng S, Kleyman TR. On the interaction between amiloride and its putative alpha-subunit epithelial $\mathrm{Na}+$ channel binding site. $\mathrm{J}$ Biol Chem. 2005;280(28):26206-15.

Kim S, Iwao H. Molecular and cellular mechanisms of angiotensin II-mediated cardiovascular and renal diseases. Pharmacol Rev. 2000;52(1):11-34.

Kobayashi CA, Leite AL, Silva TL, Santos LD, Nogueira FC, Oliveira RC, et al. Proteomic analysis of kidney in rats chronically exposed to fluoride. Chem Biol Interact. 2009;180(2):305-11.

Kokko JP. The role of the collecting duct in urinary concentration. Kidney Int. 1987;31:606-10.

Kozlowski FC, Pereira AC. Métodos de utilização de flúor sistêmico. In: Pereira A.C. Odontologia em saúde coletiva. Porto Alegre: Editora Artmed; p.265-274, 2003.

Kueng W, Silber E, Eppenberger U. Quantification of cells cultured on 96-well plates. Anal Biochem. 1989;182(1):16-9.

Loffing J, Korbmacher $\mathrm{C}$. Regulated sodium transport in the renal connecting tubule (CNT) via the epithelial sodium channel (ENaC). Pflugers Arch. 2009;458(1):111-35.

Masilamani S, Kim GH, Mitchell C, Wade JB, Knepper MA. Aldosterone-mediated regulation of $\mathrm{ENaC}$ alpha, beta, and gamma subunit proteins in rat kidney. $\mathrm{J}$ Clin Invest. 1999;104(7):R19-23.

Mazze RI, Calverley RK, Smith NT. Inorganic fluoride nephrotoxicity: prolonged enflurane and halothane anesthesia in volunteers. Anesthesiology. 1977;46(4):26571.

Mori Y, Kawasaki A, Takamaki A, Kitano I, Yoshida R, Kubokawa M, et al. Ca(2+)dependent inhibition of inwardly rectifying $\mathrm{K}(+)$ channel in opossum kidney cells. Jpn J Physiol. 2001;51(3):371-80.

Mosmann T. Rapid colorimetric assay for cellular growth and survival: application to proliferation and cytotoxicity assays. J Immunol Methods. 1983;65(1-2):55-63. 
OMS, Organização Mundial da Saúde. Fluoride in drinking-water. In: Fawell, J., Bailey,K., Chilton, J., Dahi, E., Fewtrell, L., Magara, Y. (Eds.), OMS Drinking Water Quality Series. TJ International, Padstow, Cornwall, UK, pp. 4-22, 2006.

O'Neil H, Lebeck J, Collins PB, Kwon TH, Frokiaer J, Nielsen S. Apical segment of aldosterone mediated by $\mathrm{ENaC}$ subunits is attenuated in rats with diabetes induced by streptozotocin. Nephrol Dial Transplant. 2008;23:1546-55.

Parmar MS. Chronic renal disease. BMJ. 2002;325(7355):85-90.

Parnell C, Whelton H, O'Mullane D. Water fluoridation. Eur Arch Paediatr Dent. 2009;10(3):141-8.

Pearce D, Soundararajan R, Trimpert C, Kashlan OB, Deen PM, Kohan DE. Collecting duct principal cell transport processes and their regulation. Clin $\mathrm{J}$ Am Soc Nephrol. 2015;10(1):135-46.

Peckham S, Awofeso N. Water fluoridation: a critical review of the physiological effects of ingested fluoride as a public health intervention. ScientificWorldJournal. 2014;2014:293019.

Peixoto, EMA. “Elemento químico flúor.” Química Nova. 1998;8:43.

Petty KJ, Kokko JP, Marver D. Secondary effect of aldosterone on Na-KATPase activity in the rabbit cortical collecting tubule. J Clin Invest. 1981;68(6):1514-21.

Qin SL, Deng J, Lou DD, Yu WF, Pei J, Guan ZZ. The decreased expression of mitofusin-1 and increased fission-1 together with alterations in mitochondrial morphology in the kidney of rats with chronic fluorosis may involve elevated oxidative stress. J Trace Elem Med Biol. 2015;29:263-8.

Refsnes M, Schwarze PE, Holme JA, Låg M. Fluoride-induced apoptosis in human epithelial lung cells (A549 cells): role of different G protein-linked signal systems. Hum Exp Toxicol. 2003;22(3):111-23.

Refsnes M, Thrane EV, Låg M, Thoresen GH, Schwarze PE. Mechanisms in fluorideinduced interleukin-8 synthesis in human lung epithelial cells. Toxicology. 2001;167(2):145-58. 
Renard S, Voilley N, Bassilana F, Lazdunski M, Barbry P. Localization and regulation by steroids of the $\alpha, \beta$, and $\gamma$ subunits of the amiloride-sensitive $\mathrm{Na}+$ channel in colon, lung, and kidney. Pflugers Arch 1995;430:299.

Rossier BC, Baker ME, Studer RA. Epithelial sodium transport and its control by aldosterone: the story of our internal environment revisited. Physiol Rev. 2015;95(1):297-340.

Rotin D, Kanelis V, Schild L. Trafficking and cell surface stability of ENaC. Am J Physiol Renal Physiol. 2001;281(3):F391-9.

Santoyo-Sanchez MP, del Carmen Silva-Lucero M, Arreola-Mendoza L, Barbier OC. Effects of acute sodium fluoride exposure on kidney function, water homeostasis, and renal handling of calcium and inorganic phosphate. Biol Trace Elem Res. 2013;152(3):367-72.

Schild L. The epithelial sodium channel and the control of sodium balance. Biochim Biophys Acta. 2010;1802(12):1159-65.

Shanthakumari D, Srinivasalu S, Subramanian S. Effect of fluoride intoxication on lipidperoxidation and antioxidant status in experimental rats. Toxicology. 2004;204(23):219-28.

Silverthorn, DU. Fisiologia Humana: uma abordagem integrada. 5. ed. Porto Alegre: Artmed; 2010.

Smith F, Ekstrand J. The occurrence and the chemistry of fluoride. Fluoride in dentistry. Fejerskov O, Burt BA, Ekstrand J. 1996:17-26.

Snyder P M, McDonald F J, Stokes JB, Welsh M J. Membrane topology of the amiloridesensitive epithelial sodium channel. J Biol Chem. 1994;269:24379-83.

Snyder PM. Minireview: regulation of epithelial $\mathrm{Na}+$ channel trafficking. Endocrinology. 2005;146(12):5079-85.

Song GH, Gao JP, Wang CF, Chen CY, Yan XY, Guo M, et al. Sodium fluoride induces apoptosis in the kidney of rats through caspase-mediated pathways and DNA damage. J Physiol Biochem. 2014;70(3):857-68. 
Staruschenko A. Regulation of transport in the connecting tubule and cortical collecting duct. Compr Physiol. 2012;2(2):1541-84.

Stewart AP, Haerteis S, Diakov A, Korbmacher C, Edwardson JM. Atomic force microscopy reveals the architecture of the epithelial sodium channel (ENaC). J Biol Chem. 2011;286(37):31944-52.

Stockand JD. Vasopressin regulation of renal sodium excretion. Kidney Int. 2010;78(9):849-56.

Stokes JB, Sigmund RD. Regulation of rENaC mRNA by dietary $\mathrm{NaCl}$ and steroids: organ, tissue, and steroid heterogeneity. Am J Physiol. 1998;274(6 Pt 1):C1699-707.

Timmermans PB, Wong PC, Chiu AT, Herblin WF, Benfield P, Carini DJ, et al. Angiotensin II receptors and angiotensin II receptor antagonists. Pharmacol Rev. 1993;45(2):205-51.

Tortora GJ. Corpo humano, fundamentos de anatomia e fisiologia. Artmed. 4 ed. 2000.

Tubert-Jeannin S, Auclair C, Amsallem E, Tramini P, Gerbaud L, Ruffieux C, et al. Fluoride supplements (tablets, drops, lozenges or chewing gums) for preventing dental caries in children. Cochrane Database Syst Rev. 2011(12):CD007592.

Verrey F, Pearce D, Pfeiffer R, Spindler B, Mastroberardino L, Summa V, et al. Pleiotropic action of aldosterone in epithelia mediated by transcription and posttranscription mechanisms. Kidney Int. 2000;57(4):1277-82.

Viengchareun S, Penfornis P, Zennaro MC, Lombès M. Mineralocorticoid and glucocorticoid receptors inhibit UCP expression and function in brown adipocytes. Am J Physiol Endocrinol Metab. 2001;280(4):E640-9.

Wang AG, Xia T, Chu QL, Zhang M, Liu F, Chen XM, et al. Effects of fluoride on lipid peroxidation, DNA damage and apoptosis in human embryo hepatocytes. Biomed Environ Sci. 2004;17(2):217-22.

Whitford GM. Intake and metabolism of fluoride. Adv Dent Res. 1994;8:5-14. 
Whitford GM. The metabolism and toxicity of fluoride. Monogr Oral Sci. 1996;16 Rev 2:1-153.

Whitford GM, Pashley DH. Fluoride absorption: the influence of gastric acidity. Calcif Tissue Int. 1984;36(3):302-7.

Whitford GM, Sampaio FC, Pinto CS, Maria AG, Cardoso VE, Buzalaf MA. Pharmacokinetics of ingested fluoride: lack of effect of chemical compound. Arch Oral Biol. 2008;53(11):1037-41.

Widmaier EP, Raff H, Strang KT. Vander's human physiology: The mechanisms of body Rio de Janeiro:Guanabara Koogan, 2013.

Xiong X, Liu J, He W, Xia T, He P, Chen X, et al. Dose-effect relationship between drinking water fluoride levels and damage to liver and kidney functions in children. Environ Res. 2007;103(1):112-6.

Yu RA, Xia T, Wang AG, Chen XM. Effects of selenium and zinc on renal oxidative stress and apoptosis induced by fluoride in rats. Biomed Environ Sci. 2006;19(6):439-44.

Zager RA, Iwata M. Inorganic fluoride. Divergent effects on human proximal tubular cell viability. Am J Pathol. 1997;150(2):735-45. 
Anexos 

Anexo 1: Valores da média da triplicata biológica, comparação dos tratamentos em relação ao controle. Valores de absorbância (média e desvio-padrão) do teste de MTT nos períodos de 24, 48, 72 e 96 horas.

\begin{tabular}{|c|c|c|c|c|}
\hline \multicolumn{5}{|c|}{ Média da Triplicata Biológica - Ensaios de MTT } \\
\hline \multirow{2}{*}{$\begin{array}{c}\text { GRUPOS } \\
\text { EXPERIMENTAIS }\end{array}$} & \multicolumn{3}{|c|}{ TEMPO (HORAS) } & \multirow[b]{2}{*}{96} \\
\hline & 24 & 48 & 72 & \\
\hline \multirow{2}{*}{ Controle NaF } & $1,5553^{A}$ & $1,4853^{\mathrm{A}}$ & $1,6446^{\mathrm{A}}$ & $1,6723^{\mathrm{A}}$ \\
\hline & $\pm 0,1108$ & $\pm 0,0721$ & $\pm 0,0766$ & $\pm 0,0969$ \\
\hline \multirow{2}{*}{$10 \mu \mathrm{M} \mathrm{NaF}$} & $1,1824^{\mathrm{B}}$ & $1,1377^{\mathrm{B}}$ & $1,3131^{\mathrm{B}}$ & $1,3081^{\mathrm{B}}$ \\
\hline & $\pm 0,0681$ & $\pm 0,0693$ & $\pm 0,0683$ & $\pm 0,0846$ \\
\hline \multirow{2}{*}{$40 \mu \mathrm{M} \mathrm{NaF}$} & $0,9309^{B}$ & $0,8744^{\mathrm{B}}$ & $1,0203^{B}$ & $1,0587^{\mathrm{B}}$ \\
\hline & $\pm 0,0483$ & $\pm 0,0156$ & $\pm 0,0637$ & $\pm 0,0294$ \\
\hline \multirow{2}{*}{$100 \mu \mathrm{M} \mathrm{NaF}$} & $0,8092^{B}$ & $0,7389^{B}$ & $0,865^{\mathrm{B}}$ & $0,9463^{B}$ \\
\hline & $\pm 0,0378$ & $\pm 0,0183$ & $\pm 0,0488$ & $\pm 0,0516$ \\
\hline \multirow{2}{*}{$200 \mu \mathrm{M}$ NaF } & $0,7258^{B}$ & $0,6611^{B}$ & $0,7759^{B}$ & $0,8118^{\mathrm{B}}$ \\
\hline & $\pm 0,0347$ & $\pm 0,0149$ & $\pm 0,0352$ & $\pm 0,0447$ \\
\hline \multirow{2}{*}{$400 \mu \mathrm{M}$ NaF } & $0,7388^{B}$ & $0,7197^{\mathrm{B}}$ & $0,7934^{\mathrm{B}}$ & $0,7888^{B}$ \\
\hline & $\pm 0,0355$ & $\pm 0,0735$ & $\pm 0,017$ & $\pm 0,0611$ \\
\hline \multirow{2}{*}{ Controle NaCl } & $1,6134^{A}$ & $1,4912^{A}$ & $1,647^{\mathrm{A}}$ & $1,7632^{A}$ \\
\hline & $\pm 0,09$ & $\pm 0,077$ & $\pm 0,0373$ & $\pm 0,1355$ \\
\hline \multirow{2}{*}{$10 \mu \mathrm{M} \mathrm{NaCl}$} & $1,1955^{\mathrm{B}}$ & $1,1239^{B}$ & $1,2742^{B}$ & $1,3393^{B}$ \\
\hline & $\pm 0,0962$ & $\pm 0,06$ & $\pm 0,0676$ & $\pm 0,0448$ \\
\hline \multirow{2}{*}{$40 \mu \mathrm{M} \mathrm{NaCl}$} & $0,9191^{\mathrm{B}}$ & $0,8676^{\mathrm{B}}$ & $1,0061^{B}$ & $1,0575^{B}$ \\
\hline & $\pm 0,0274$ & $\pm 0,0205$ & $\pm 0,0729$ & $\pm 0,0141$ \\
\hline \multirow{2}{*}{$100 \mu \mathrm{M} \mathrm{NaCl}$} & $0,7776^{\mathrm{B}}$ & $0,7685^{\mathrm{B}}$ & $0,8685^{B}$ & $0,9536^{\mathrm{B}}$ \\
\hline & $\pm 0,0415$ & $\pm 0,0461$ & $\pm 0,1067$ & $\pm 0,0617$ \\
\hline \multirow{2}{*}{$200 \mu \mathrm{M} \mathrm{NaCl}$} & $0,6809^{B}$ & $0,7164^{B}$ & $0,7673^{B}$ & $0,8484^{B}$ \\
\hline & $\pm 0,0162$ & $\pm 0,0391$ & $\pm 0,0953$ & $\pm 0,0462$ \\
\hline \multirow{2}{*}{$400 \mu \mathrm{M} \mathrm{NaCl}$} & $0,6453^{B}$ & $0,7122^{\mathrm{B}}$ & $0,7398^{B}$ & $0,8302^{B}$ \\
\hline & $\pm 0,0213$ & $\pm 0,0458$ & $\pm 0,0879$ & $\pm 0,0373$ \\
\hline
\end{tabular}

Letras diferentes representam diferenças estatisticamente significantes. Obs: Não foi encontrada diferenças estatísticas entre os períodos de tempo em todos os grupos. 
Anexo 2: Comparação entre os grupos de $\mathrm{NaF}$ e $\mathrm{NaCl}$ nas mesmas concentrações. Valores de absorbância (média e desviopadrão) do teste de MTT nos períodos de 24, 48 e 72 horas.

Análise entre os grupos $\mathrm{NaF}$ e $\mathrm{NaCl}$ - Ensaios de MTT

\begin{tabular}{|c|c|c|c|c|c|c|c|c|}
\hline & \multicolumn{4}{|c|}{$\mathrm{NaF}$} & \multicolumn{4}{|c|}{$\mathrm{NaCl}$} \\
\hline & 24 horas & 48 horas & 72 horas & 96 horas & 24 horas & 48 horas & 72 horas & 96 horas \\
\hline & $1,5553^{A}$ & $1,4853^{B}$ & $1,6446^{C}$ & $1,6723^{D}$ & $1,6134^{A}$ & $1,4912^{B}$ & $1,647^{\mathrm{C}}$ & $1,7632^{D}$ \\
\hline Controle & $\pm 0,1108$ & $\pm 0,0721$ & $\pm 0,0766$ & $\pm 0,0969$ & $\pm 0,09$ & $\pm 0,077$ & $\pm 0,0373$ & $\pm 0,1355$ \\
\hline $10 \mu \mathrm{M}$ & $\begin{array}{l}1,1824^{E} \\
\pm 0,0681\end{array}$ & $\begin{array}{r}1,1377^{F} \\
\pm 0,0693\end{array}$ & $\begin{array}{c}1,3131^{G} \\
\pm 0,0683\end{array}$ & $\begin{array}{l}1,3081^{H} \\
\pm 0,0846\end{array}$ & $\begin{array}{r}1,1955^{E} \\
\pm 0,0962\end{array}$ & $\begin{array}{c}1,1239^{F} \\
\pm 0,06\end{array}$ & $\begin{array}{l}1,2742^{G} \\
\pm 0,0676\end{array}$ & $\begin{array}{l}1,3393^{\mathrm{H}} \\
\pm 0,0448\end{array}$ \\
\hline $40 \mu \mathrm{M}$ & $0,9309^{\prime}$ & $0,8744^{\mathrm{J}}$ & $1,0203^{K}$ & $1,0587^{L}$ & 0,9191' & $0,8676^{\mathrm{J}}$ & $1,0061^{\mathrm{K}}$ & $1,0575^{\mathrm{L}}$ \\
\hline 40 pivi & $\pm 0,0483$ & $\pm 0,0156$ & $\pm 0,0637$ & $\pm 0,0294$ & $\pm 0,0274$ & $\pm 0,0205$ & $\pm 0,0729$ & $\pm 0,0141$ \\
\hline & $0,8092^{M}$ & $0,7389^{N}$ & $0,865^{\circ}$ & $0,9463^{P}$ & $0,7776^{\mathrm{M}}$ & $0,7685^{\mathrm{N}}$ & $0,8685^{\circ}$ & $0,9536^{P}$ \\
\hline & $\pm 0,0378$ & $\pm 0,0183$ & $\pm 0,0488$ & $\pm 0,0516$ & $\pm 0,0415$ & $\pm 0,0461$ & $\pm 0,1067$ & $\pm 0,0617$ \\
\hline & $0,7258^{Q}$ & $0,6611^{R}$ & $0,7759^{\mathrm{s}}$ & $0,8118^{\top}$ & $0,6809^{Q}$ & $0,7164^{\mathbf{R}}$ & $0,7673^{s}$ & $0,8484^{\top}$ \\
\hline 20 & $\pm 0,0347$ & $\pm 0,0149$ & $\pm 0,0352$ & $\pm 0,0447$ & $\pm 0,0162$ & $\pm 0,0391$ & $\pm 0,0953$ & $\pm 0,0462$ \\
\hline $400 \mu \mathrm{M}$ & $\begin{array}{l}0,7388^{U} \\
\pm 0,0355\end{array}$ & $\begin{array}{l}0,7197^{v} \\
\pm 0,0735\end{array}$ & $\begin{array}{c}0,7934^{w} \\
\pm 0,017\end{array}$ & $\begin{array}{l}0,7888^{x} \\
\pm 0,0611\end{array}$ & $\begin{array}{l}0,6453^{U} \\
\pm 0,0213\end{array}$ & $\begin{array}{l}0,7122^{v} \\
\pm 0,0458\end{array}$ & $\begin{array}{l}0,7398^{w} \\
\pm 0,0879\end{array}$ & $\begin{array}{l}0,8302^{x} \\
\pm 0,0373\end{array}$ \\
\hline
\end{tabular}


Anexo 3: Valores da média da triplicata biológica, comparação dos tratamentos em relação ao controle. Valores de absorbância (média e desvio-padrão) do teste de Cristal Violeta nos períodos de 24, 48, 72 e 96 horas.

\begin{tabular}{|c|c|c|c|c|}
\hline \multicolumn{5}{|c|}{ Média da Triplicata Biológica - Cristal Violeta } \\
\hline \multirow{2}{*}{$\begin{array}{c}\text { GRUPOS } \\
\text { EXPERIMENTAIS }\end{array}$} & \multicolumn{3}{|c|}{ TEMPO (HORAS) } & \multirow[b]{2}{*}{96} \\
\hline & 24 & 48 & 72 & \\
\hline \multirow{2}{*}{ Controle NaF } & $2,5888^{A}$ & $2,754^{\mathrm{A}}$ & $2,8592^{A}$ & $2,998^{\mathrm{A}}$ \\
\hline & $\pm 0,3149$ & $\pm 0,1413$ & $\pm 0,1189$ & $\pm 0,1487$ \\
\hline \multirow{2}{*}{$10 \mu \mathrm{M} \mathrm{NaF}$} & $2,6291^{A}$ & $2,76878^{A}$ & $2,7059^{A}$ & $2,8081^{A}$ \\
\hline & $\pm 0,1287$ & $\pm 0,0706$ & $\pm 0,158$ & $\pm 0,1442$ \\
\hline \multirow{2}{*}{$40 \mu \mathrm{M} \mathrm{NaF}$} & $2,5206^{\mathrm{A}}$ & $2,69539^{A}$ & $2,7219^{A}$ & $2,5349^{B}$ \\
\hline & $\pm 0,1492$ & $\pm 0,1589$ & $\pm 0,097$ & $\pm 0,2406$ \\
\hline \multirow{2}{*}{$100 \mu \mathrm{M} \mathrm{NaF}$} & $2,471^{\mathrm{A}}$ & $2,53097^{\mathbf{A}}$ & $2,5534^{\mathrm{A}}$ & $2,5041^{B}$ \\
\hline & $\pm 0,1611$ & $\pm 0,161$ & $\pm 0,1107$ & $\pm 0,2092$ \\
\hline \multirow{2}{*}{$200 \mu \mathrm{M} \mathrm{NaF}$} & $2,3976^{A}$ & $2,39092^{B}$ & $2,4529^{B}$ & $2,3836^{B}$ \\
\hline & $\pm 0,2597$ & $\pm 0,2271$ & $\pm 0,1139$ & $\pm 0,2371$ \\
\hline \multirow{2}{*}{$400 \mu \mathrm{M}$ NaF } & $2,2693^{A}$ & $318335^{B}$ & $2,1584^{B}$ & $2,2228^{B}$ \\
\hline & $\pm 0,2871$ & \pm 779753 & $\pm 0,2658$ & $\pm 0,2418$ \\
\hline
\end{tabular}

\begin{tabular}{|c|c|c|c|c|}
\hline \multirow{3}{*}{$\begin{array}{c}\text { GRUPOS } \\
\text { EXPERIMENTAIS }\end{array}$} & \multicolumn{3}{|c|}{ TEMPO (HORAS) } & \multirow{3}{*}{$\begin{array}{c}96 \\
\text { b }\end{array}$} \\
\hline & 24 & 48 & 72 & \\
\hline & a & b & $a b$ & \\
\hline \multirow{2}{*}{ Controle $\mathrm{NaCl}$} & $2,7172^{A}$ & $3,19742^{A}$ & $2,7672^{A}$ & $2,8924^{A}$ \\
\hline & $\pm 0,0837$ & $\pm 0,1233$ & $\pm 0,2259$ & $\pm 0,2312$ \\
\hline \multirow{2}{*}{$10 \mu \mathrm{M} \mathrm{NaCl}$} & $2,5236^{A}$ & $3,145333^{A}$ & $2,7243^{A}$ & $2,7464^{A}$ \\
\hline & $\pm 0,0931$ & $\pm 0,2096$ & $\pm 0,1302$ & $\pm 0,198$ \\
\hline \multirow{2}{*}{$40 \mu \mathrm{M} \mathrm{NaCl}$} & $2,4212^{A}$ & $2,85264^{A}$ & $2,5124^{A}$ & $2,6927^{A}$ \\
\hline & $\pm 0,0995$ & $\pm 0,1476$ & $\pm 0,2073$ & $\pm 0,1526$ \\
\hline \multirow{2}{*}{$100 \mu \mathrm{M} \mathrm{NaCl}$} & $2,2361^{\mathrm{B}}$ & $2,82239^{B}$ & $2,6237^{\mathrm{A}}$ & $2,5965^{A}$ \\
\hline & $\pm 0,1139$ & $\pm 0,1329$ & $\pm 0,167$ & $\pm 0,1116$ \\
\hline \multirow{2}{*}{$200 \mu \mathrm{M} \mathrm{NaCl}$} & $2,2731^{\mathrm{B}}$ & $2,71528^{B}$ & $2,4727^{A}$ & $2,7322^{A}$ \\
\hline & $\pm 0,0637$ & $\pm 0,144$ & $\pm 0,2095$ & $\pm 0,0971$ \\
\hline \multirow{2}{*}{$400 \mu \mathrm{M} \mathrm{NaCl}$} & $2,2566^{\mathrm{B}}$ & $2,69044^{B}$ & $2,5478^{A}$ & $2,5459^{A}$ \\
\hline & $\pm 0,1426$ & $\pm 0,1142$ & $\pm 0,1658$ & $\pm 0,1297$ \\
\hline
\end{tabular}

Letras maiúsculas diferentes representam diferenças estatisticamente significantes entre os grupos.

Letras minúsculas iguais representam não haver diferenças significativas entre os períodos. Não foram encontradas diferenças estatísticas entre os períodos de tempo para $\mathrm{NaF}$. 
Anexo 4: Comparação entre os grupos de $\mathrm{NaF}$ e $\mathrm{NaCl}$ nas mesmas concentrações. Valores de absorbância (média e desviopadrão) do teste de Cristal Violeta nos períodos de 24, 48 e 72 horas.

Análise entre os grupos $\mathrm{NaF}$ e $\mathrm{NaCl}$ - Ensaio Cristal Violeta

\begin{tabular}{|c|c|c|c|c|c|c|c|c|}
\hline \multicolumn{9}{|c|}{ Análise entre os grupos $\mathrm{NaF}$ e $\mathrm{NaCl}$ - Ensaio Cristal Violeta } \\
\hline & \multicolumn{4}{|c|}{ NaF } & \multicolumn{4}{|c|}{$\mathrm{NaCl}$} \\
\hline & 24 horas & 48 horas & 72 horas & 96 horas & 24 horas & 48 horas & 72 horas & 96 horas \\
\hline \multirow{2}{*}{ Controle } & 2,5888 & 2,754 & 2,8592 & 2,998 & 2,7172 & 3,19742 & 2,7672 & 2,8924 \\
\hline & $\pm 0,3149$ & $\pm 0,1413$ & $\pm 0,1189$ & $\pm 0,1487$ & $\pm 0,0837$ & $\pm 0,1233$ & $\pm 0,2259$ & $\pm 0,2312$ \\
\hline \multirow{2}{*}{$10 \mu \mathrm{M}$} & 2,6291 & 2,76878 & $2,7059^{7}$ & 2,8081 & 2,5236 & 3,145333 & 2,7243 & 2,7464 \\
\hline & $\pm 0,1287$ & $\pm 0,0706$ & $\pm 0,158$ & $\pm 0,1442$ & $\pm 0,0931$ & $\pm 0,2096$ & $\pm 0,1302$ & $\pm 0,198$ \\
\hline \multirow{2}{*}{$40 \mu \mathrm{M}$} & 2,5206 & 2,69539 & 2,7219 & $2,5349^{12}$ & 2,4212 & 2,85264 & 2,5124 & 2,6927 \\
\hline & $\pm 0,1492$ & $\pm 0,1589$ & $\pm 0,097$ & $\pm 0,2406$ & $\pm 0,0995$ & $\pm 0,1476$ & $\pm 0,2073$ & $\pm 0,1526$ \\
\hline \multirow{2}{*}{$100 \mu \mathrm{M}$} & 2,471 & 2,53097 & 2,5534 & 2,5041 & 2,2361 & 2,82239 & 2,6237 & 2,5965 \\
\hline & $\pm 0,1611$ & $\pm 0,161$ & $\pm 0,1107$ & $\pm 0,2092$ & $\pm 0,1139$ & $\pm 0,1329$ & $\pm 0,167$ & $\pm 0,1116$ \\
\hline \multirow{2}{*}{$200 \mu \mathrm{M}$} & 2,3976 & 2,39092 & 2,4529 & 2,3836 & 2,2731 & 2,71528 & 2,4727 & 2,7322 \\
\hline & $\pm 0,2597$ & $\pm 0,2271$ & $\pm 0,1139$ & $\pm 0,2371$ & $\pm 0,0637$ & $\pm 0,144$ & $\pm 0,2095$ & $\pm 0,0971$ \\
\hline \multirow{2}{*}{$400 \mu \mathrm{M}$} & 2,2693 & $318335^{\mathbf{A}}$ & $2,1584^{\mathrm{B}}$ & 2,2228 & 2,2566 & $2,69044^{A}$ & $2,5478^{\mathrm{B}}$ & 2,5459 \\
\hline & $\pm 0,2871$ & \pm 779753 & $\pm 0,2658$ & $\pm 0,2418$ & $\pm 0,1426$ & $\pm 0,1142$ & $\pm 0,1658$ & $\pm 0,1297$ \\
\hline
\end{tabular}


Anexo 5: Comparação da expressão de Scnn1a gênica entre os grupos experimentais de tratamento com $\mathrm{NaF}$.

\begin{tabular}{|c|c|c|}
\hline \multicolumn{3}{|c|}{ Expressão de Scnn1a - comparação entre os grupos experimentais } \\
\hline \multirow{2}{*}{ GRUPOS EXPERIMENTAIS } & \multicolumn{2}{|c|}{ TEMPO (HORAS) } \\
\hline & 24 & 48 \\
\hline \multirow{2}{*}{$100 \mu \mathrm{M} \mathrm{NaF}$} & $1,6^{\mathrm{A}}$ & $3,0367^{A}$ \\
\hline & $\pm 0,0917$ & $\pm 0,6018$ \\
\hline \multirow{2}{*}{$200 \mu \mathrm{M} \mathrm{NaF}$} & $1,7633^{\mathbf{A}}$ & $2,37^{\mathbf{A}}$ \\
\hline & $\pm 0,2259$ & $\pm 0,3342$ \\
\hline \multirow{2}{*}{$400 \mu \mathrm{M} \mathrm{NaF}$} & $0,6967^{\mathrm{B}}$ & $0,4133^{\mathrm{B}}$ \\
\hline & $\pm 0,1012$ & $\pm 0,0709$ \\
\hline
\end{tabular}

Letras diferentes representam diferenças estatisticamente significantes.

Anexo 6: Comparação da expressão gênica de Scnn1b entre os grupos experimentais de tratamento com $\mathrm{NaF}$.

\section{Expressão de Scnn1b - comparação entre os grupos experimentais}

\begin{tabular}{ccc}
\hline \multirow{2}{*}{ GRUPOS EXPERIMENTAIS } & \multicolumn{2}{c}{ TEMPO (HORAS) } \\
\cline { 2 - 3 } & $\mathbf{2 4}$ & $\mathbf{4 8}$ \\
\hline \multirow{2}{*}{$\mathbf{1 0 0} \boldsymbol{\mu M ~ N a F}$} & $1,53^{\mathrm{A}}$ & $2,89^{\mathrm{A}}$ \\
& $\pm 0,2007$ & $\pm 0,9707$ \\
\multirow{2}{*}{$\mathbf{2 0 0} \boldsymbol{\mu M ~ N a F}$} & $1,6033^{\mathrm{A}}$ & $2,2533^{\mathrm{A}}$ \\
& $\pm 0,3066$ & $\pm 0,4102$ \\
\multirow{4}{4}{$\mathbf{4 0 0} \boldsymbol{\mu M ~ N a F}$} & $0,3833^{\mathrm{B}}$ & $0,1733^{\mathrm{B}}$ \\
& $\pm 0,1007$ & $\pm 0,0611$ \\
\hline
\end{tabular}

Letras diferentes representam diferenças estatisticamente significantes. 
Anexo 7: Comparação da expressão gênica de Scnn1g entre os grupos experimentais de tratamento com $\mathrm{NaF}$.

\begin{tabular}{ccc}
\hline \multicolumn{3}{c}{ Expressão de Scnn1g - comparação entre os grupos experimentais } \\
\hline \multirow{2}{*}{ GRUPOS EXPERIMENTAIS } & \multicolumn{2}{c}{ TEMPO (HORAS) } \\
& $\mathbf{2 4}$ & $\mathbf{4 8}$ \\
\hline \multirow{2}{*}{$\mathbf{1 0 0} \boldsymbol{\mu M ~ N a F}$} & $1,4833^{\mathrm{A}}$ & $2,7567^{\mathrm{A}}$ \\
& $\pm 0,1124$ & $\pm 0,1704$ \\
\multirow{2}{2}{$\mathbf{2 0 0} \boldsymbol{\mu M ~ N a F}$} & $1,8033^{\mathrm{A}}$ & $2,1067^{\mathrm{B}}$ \\
& $\pm 0,4325$ & $\pm 0,1361$ \\
\multirow{2}{*}{$\mathbf{4 0 0} \boldsymbol{\mu M ~ N a F}$} & $0,3933^{\mathrm{B}}$ & $0,29^{\mathrm{C}}$ \\
& $\pm 0,0757$ & $\pm 0,0854$ \\
\hline
\end{tabular}

Letras diferentes representam diferenças estatisticamente significantes. 
